\title{
RACIONALIDAD Y MÉTODO PARA EL DERECHO: ¿ES ESO POSIBLE? (I)
}

\begin{abstract}
A la memoria de Michel Villell, († 1938), recordando el invalorable aliento y apoyo que supo brindar para la publicación de estudios que, como el presente, defienden puntos de vista con los que él no estaba de acuerdo.

No puede haber obstáculo mayor al desarrollo de la racionalidad que la ilusión de que se es racional cuando se es víctima de ilusiones. El hombre no puede inventar mejor medio para entrabar cualquiera de sus ideales, que el engañarse creyendo que han sido ya alcanzados.
\end{abstract}

J. Frank

Ateniéndome a la máxima de Hegel: «Todo lo que es, es racional», confío en vencer cualquier obstáculo. A quien no concuerde conmigo, le negaré la facultad de comprender lo racional.

Jhering

The existence of such principles does not guarantee that men will apply them -any more than the existence of logic can guarantee that men shall think logicallybut their existence does guarantee the possibility of objective knowledge, and that is the major thesis which this book undertakes to defend.

E. D. Hirsch, Jr. ${ }^{1}$

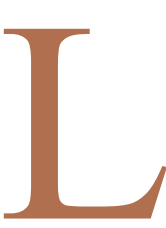

as palabras «racionalidad» y «método» son utilizadas a menudo con referencia al derecho, especialmente en estudios actuales. En sentido muy amplio, método puede querer decir simplemente: un procedimiento cualquiera, y sea intelectual o material. Mas entonces la cuestión de saber si el derecho es o no es método no se plantearía, pues nadie ignora que las soluciones jurídicas se adoptan

* Este estudio retorna, con ampliaciones, los desarrollos de un capítulo (§§ 4-8) de mi tesis doctoral, Langagejuridique et interprétation littérale (envisagés sous l'angle de la possibilitéd'une méthodologie pour interprétation des lois), Université de Droit, d'Economie et de Sciences Sociales de París (París 
con ayuda de ciertos procedimientos intelectuales. ${ }^{2}$ Sin embargo, en la discusión sobre el método jurídico, este término aparece empleado también de acuerdo con sentidos más estrechos: muchos dicen que los juristas apelan a procedimientos verdaderamente metódicos en cuanto son racionales, o por lo menos «razonables». Pero también éstas son palabras ambiguas. Por lo demás, no todo lo que es racional corresponde forzosamente a un método; racionalidad y método no son del todo sinónimos.

La polisemia de los susodichos términos provoca malentendidos, origina confusiones en la apreciación del resultado práctico a que las posiciones sostenidas por unos u otros puede conducir.

II), 1977, XXVII + 448 págs. [El Índice Analítico y las Conclusiones Generales de dicha tesis, en traducción al castellano, están publicados en Archivos Latinoamericanos de Metodología y Filosofía del Derecho (ALMFD) 1, 1980, págs. 129-147, Valencia (Venezuela).] Quiero agradecer especialmente a mi director de tesis, Michel Villey, como asimismo a los miembros del jurado, Henri Batiffol y Georges Kalinowski, por sus observaciones en ocasión de sostenerla, las que he tomado en cuenta para introducir ciertas modificaciones en la primera versión publicada de este trabajo. Y deseo también hacer extensivo mi agradecimiento a la Alexander von Humboldt-Stifung de la República Federal Alemana, pues lo que expongo es, en buena medida, fruto de estudios efectuados por mí en dicho país (1974-1976) como investigador de esa institución. [La versión mencionada se publicó en Archives de Philosophie du Droit, t. 23 (1978), págs. 265-293, bajo el título «Rationalité et méthode dans le droit». En la misma época, por otro lado, retomé la mayor parte de lo allí expuesto, pero enfocando esos temas desde un ángulo más general -esto es, sin referirme particularmente al pensamiento jurídico- y añadiendo desarrollos que no contiene aquélla: «Lo racional y lo razonable», Revista de Filosofía de la Universidad de Costa Rica, núm. 43 (enero-julio 1978), págs. 1-32. Lo que ofrezco ahora es una traducción al castellano del artículo francés, pero trato aquí de lograr más precisión en ciertos puntos, e incorporo algunos complementos (en el texto mismo, además del Postscriptum, el Apéndice y el Anexo).]

'El Apéndice y el Anexo de este trabajo aparecerán en el próximo número de $D O X A$.

${ }^{1}$ Frank: Law..., pág. XXX. [Cuando, como en esta referencia y la siguiente, se indica el nombre del autor sin otros datos bibliográficos, entonces se trata de un trabajo de dicho autor que se consigna en la lista de obras (Literatura escogida) ubicada al final del estudio, antes del Apéndice.] Jhering, pág. 349. E. D. Hirsch, Jr., Validity in Interpretation, Yale University Press, New Haven-Londres, 1967, pág. 180 («La existencia de tales principios no garantiza que los hombres querrán aplicarlos -así como la existencia de la lógica no puede garantizar que los hombres pensarán en forma lógica-, pero su existencia garantiza sí la posibilidad del conocimiento objetivo, y esa es la tesis principal que este libro se propone sostener» [en esta y otras citas tomadas de textos en lenguas extranjeras, la traducción al castellano corre por mi cuenta -E. P. H.-]).

2 «Por método jurídico, el jurista entiende cualquier técnica de aproximación al fenómeno jurídico en su realidad histórica, humana y social, y además 
Para saber si, y en qué medida, racionalidad y método existen o pueden llegar a existir en el derecho, antes que nada sería necesario conocer mejor el sentido en que estas palabras claves son empleadas en cada caso: ¿qué racionalidad?, ¿qué método? He ahí lo que se intentará precisar en el presente estudio, ya que eso constituye la base misma para responder a la pregunta formulada como título.

\section{INTRODUCCIÓN}

Hay que empezar por advertir que lo racional no es más que un aspecto del pensamiento jurídico. Como Radbruch lo señalara en cuanto a la interpretación del derecho, éste se compone de «una mezcla indisoluble de elementos teoréticos y prácticos, cognitivos y creativos, reproductivos y productivos, científicos y supracientíficos, objetivos y subjetivos». O como dice Cowan, se trata de un «centro en torno del cual se combina, en mayor o menor grado, una singular mezcla de ciencia, mitos, supersticiones, folclor y usos tradicionales de antiquísimas tecnologías»». ${ }^{3}$

la técnica de interpretación del derecho» (Brimo, pág. 217). «Por método se entiende, en consonancia con la etimología del término, la vía a seguir para alcanzar una meta, un resultado correcto. Se dice que esa vía consiste en una serie de indicaciones para la solución de problemas; o en el conjunto de los procedimientos intelectuales requeridos para llevar una investigación al fin deseado; o en 'una serie de operaciones-tipo dispuestas en razón de un cierto resultado', etc.» (García, pág. 176). Comparando tales definiciones de «método» o incluso la de Larenz: infra, nota 29, con la que será propuesta aquí al respecto, puede decirse que aquéllas representan una noción muy extensiva, mientras que la nuestra se refiere a los métodos propiamente dichos, métodos en sentido estricto. Empero, aun dicha noción extensiva puede ser más (por ejemplo, Brimo) o ser algo menos (p. ej., García o Larenz) elástica, por lo cual cabe allí distinguir entre métodos en el sentido más lato y métodos científicos en sentido amplio: cfr. infra, VIII in line y el esquema que está al final del Anexo.

Gustav Radbruch, Rechtphilosophie (7. . ed., por Erik Wolf), E. F. Koehler, Stuttgart, 1970, pág. 211 [hay trad. de José Medina Echavarría, «Filosofía del Derecho», Revista del Derecho Privado, Madrid]. Thomas A. Cowan, «The Relation of Law to Experimental Social Science», en University of Pennsylvania Law Review 96 (1947-48), págs. 484-502; he tomado la cita de la traducción al alemán por Ursula Funke, «Das Verhältnis des Rechts zur experimentellen Sozialwissenschaft», en Studien und Materialien zur Rechtssoziologie, Kölner Zeitschrift für Soziologie und Sozialpsychologie, Sonderheft 11/1967, págs. 161-181 (ahí pág. 162), Westdeutscher Verlag Opladen. Cfr. también las líneas de Cowan y de David transcritas infra, VIII in fine (Excurso). 
Efectivamente, en el razonamiento de los juristas hay más que lo racional, e incluso más que lo razonable. De ahí que un examen sólo de los aspectos racionales del derecho, entre los cuales están los métodos, nunca será capaz de dar cuenta del fenómeno jurídico entero, de toda su complejidad.

Racionalidad y método son términos prestigiosos; implican, así sea tácitamente, una afirmación de valor, pues presentan también un aspecto emocional, «persuasivo» (Stevenson). Todos quisieran poder reivindicar estas palabras para legitimar las soluciones propias. A nadie le gustará tener que admitir que éstas no son (o que sólo son débilmente) racionales, menos metódicas que las de otros procedimientos posibles. Todo teórico del derecho entiende que él propone unas vías racionales, o razonables, para la práctica jurídica. Empero, al decir que son tales, no se toma en cuenta sólo aquello que para la ejecución material, la práctica de lo que cada quien llama racional, es el sentido objetivo, descriptivo, de los procedimientos así calificados. El aspecto emocional sirve para otorgar automáticamente una valoración aprobativa a cualquier sentido objetivo ligado a dichos términos. Al afirmar que tal o cual cosa es «racional», se afirma asimismo -por dinámica propia de este lenguaje- que esa cosa es «buena». Las cuestiones de palabras que de ello resultan, a propósito de semejante calificación, representan así diferencias más profundas. Quienes sostienen que el derecho es racional ya, están de acuerdo en reconocer que las vías de pensamiento tradicionales de los juristas son buenas, consideran que nada fundamental merece ser cambiado en tal práctica. En cambio, quienes toman las palabras racionalidad y método en un sentido que es más exigente desde el punto de vista científico, estiman que esa práctica no es satisfactoria, que debería ser reemplazada, cuando menos parcialmente, por otros tipos de procedimientos. Y hasta en el interior mismo de estas dos grandes tendencias, siempre existe la posibilidad de discrepancias sobre el sentido de dichos términos.

Por ende, cada definición de la racionalidad es una elección que conlleva importantes consecuencias prácticas. La acepción elegida depende de los fines que se persigan mediante los procedimientos que serán llamados racionales. Determinada clase de procedimientos se prefiere, por unos, porque les parece adecuada con vistas a lograr un fin (valor); y a este procedimiento le llaman «racional» o «razonable», justamente porque permitiría alcanzar ese fin. Por ejemplo, si se prefiere (fin) que el juez pueda dictar su sentencia de manera relativamente libre, se abogará por unos «métodos» tan elásticos que nadie conseguirá saber de 
antemano lo que el juez decidirá en concreto, ni tampoco se podría luego mostrar de manera indisputable que él pueda haberse equivocado; tales procedimientos serán calificados, así y todo, como racionales o razonables, por sus partidarios -los cuales, en el fondo, confían en que el juez siempre decidirá de acuerdo con la ideología política y social dominante en ese Estado, con la cual ellos están sustancialmente de acuerdo-. En cambio, si se prefiere (fin) que los resultados sean mucho más previsibles o controlables, esto es, que el juez sea lo menos libre posible, entonces se toma partido por otros métodos, y sólo a estos se les reconoce la condición de ser verdaderamente «racionales» -posición que, desde luego, puede adoptarse con o sin intenciones críticas respecto al status quo político-social.

Por mi parte, deseo reservar para esos términos un sentido que esté lo más próximo posible del que ellos tienen cuando son utilizados en las ciencias empíricas. Esto corresponde a una finalidad, por supuesto; la de que por medio de los procedimientos así denominados, puedan obtenerse en forma más segura, menos equívoca, los resultados jurídicos. Esos procedimientos serán racionales, en tal sentido, análogamente a como lo son los métodos de las ciencias, sobre todo los de las ciencias sociales: sociología, ciencia política, etc. (en la medida, claro, en que estas disciplinas acudan a métodos propiamente dichos $)^{4}$

Cada ciencia elabora o recoge unos modelos particulares de racionalidad. No obstante, hay nociones más generales de racionalidad, respecto a las cuales los modelos particulares constituyen sus especies. Esas nociones generales significan un punto de partida, una orientación primaria -explícita o implícita- que permite saber mejor lo que hay que buscar para elaborar o para adaptar los que sirvan en cada disciplina. La noción general tiene una virtud heurística respecto a los modelos particulares. Si no se empieza por tener una idea bastante clara sobre este punto de partida, sobre el género de procedimientos encarado, resulta más fácil extraviarse en la búsqueda de los modelos particulares. Por eso, será señalada la noción más general de racionalidad y de método, tal y como aparece presupuesta en la práctica de las ciencias. Ello puede tener su interés sobre todo para el derecho, ya que en él, justamente, dicha precomprensión suele faltar; y

${ }^{4}$ Para una percepción más concreta de cómo es o sería posible la aplicación de tales métodos a disciplinas como el derecho, vid., por ejemplo, las precisiones que al respecto ofrecen Albert (sobre todo en su Traktat über rationales Praxis), Koch y Opp; cfr. también los trabajos indicados en la nota h, infra. 
esta falta ocasiona un verdadero caos, desde el punto de vista metodológico, en la manera como los juristas tratan los casos que tienen entre manos. ${ }^{5}$

El precisar la noción general de racionalidad y método no basta, desde luego, para alcanzar a determinar desde ya los modelos particulares que necesitaría un pensamiento jurídico que se inspire en tal noción. Lo que será subrayado aquí, no puede significar más que un primer paso hacia la respuesta a la pregunta formulada. Otros pasos serían indispensables, naturalmente, y claro que son éstos los más difíciles de concretar. Pero tal vez nuestras observaciones puedan ayudar a hacer conciencia de la dirección en que esos otros pasos deben ser dados si se quisiera obtener un pensamiento jurídico más científico. Se trata de destacar las exigencias que la adopción de un pensamiento de esta clase precisamente, el científico, le impondría al jurista, y distinguir en la forma más neta posible esta racionalidad frente a otros tipos de pensamiento, llámeseles o no «racionales» también. Es, en definitiva, una manera de advertir acerca de lo que acaso podría ser querido -aunque en la actualidad no lo sea por los juristas, como patrón de su actividad profesional. Asunto que tiene su interés, me parece, no sólo para los particulares de una racionalidad como la que aquí será subrayada, sino hasta para sus adversarios (en el caso de éstos, para que puedan rechazarla con mejor conocimiento de causa).

\section{LA NOCIÓN DE MÉTODO}

La racionalidad científica se caracteriza especialmente por la condición de que ella se vierte en métodos. La elaboración y aplicación de éstos es, puede decirse, la condición esencial para el pensamiento racional en la ciencia.

En sentido amplio, «método» quiere decir simplemente: un «camino», algún procedimiento, sea intelectual o material. En tal sentido, cualquier medio que se emplee para lograr algo constituiría un método (cfr., por ejemplo, las definiciones transcritas en la nota 2, supra). Pero si queremos referirnos a los procedimientos científicos, los métodos propiamente dichos, entonces

${ }^{5}$ Cfr. Batiffol, Sbriccoli, Struck (Topische...), Rüthers, pero sobre todo, Frank Lautmann y Schreckenberger. De todos esos estudios resalta hasta qué punto NO es metódico (sino más bien retórico, etc.) el razonamiento común de los juristas, particularmente el de los jueces. 
esa palabra tiene un alcance mucho más restringido. En este último sentido, riguroso, estrecho, un método es el conjunto de operaciones por medio de las cuales, paso a paso, siguiendo un esquema racional, se avanza hacia un fin. Las etapas de este proceso dependen de la cosa (material o no) a la cual el respectivo método se refiere y de lo que se desee hacer con ella. El método consiste en un modelo racional -un sistema de reglas, o cuando menos una sola- que apunta a la realización de determinado género de operaciones, las que conducen, si como punto de partida están dadas ciertas condiciones, hacia una meta preestablecida. Ésta puede ser de distinta naturaleza: elaboración o transformación de bienes materiales, obtención o confirmación de nuevos conocimientos, etcétera. Y las reglas del método, a su vez, también ellas son muy variadas según la especialidad de que se trate. (Para la idea de método, vid. Rapp y sobre todo Segeth.)

Fijemos, como punto de partida, una definición provisoria:

método es el conjunto ordenado -modelo racional- de procedimientos intelectuales, y eventualmente materiales, que se emplean para un determinado tipo de actividades; estos procedimientos son medios que apuntan a ciertos aspectos de un tipo de objetos (reales o ideales), a los que el método es aplicado con la finalidad de obtener o confirmar conocimientos acerca de ellos, o bien de elaborar o transformar dichos objetos; y tales procedimientos, si el método es correcto, la experiencia los acredita como adecuados para la obtención de los conocimientos o las realizaciones prácticas así perseguidos.

(Al final de este estudio será presentada una definición algo más prolija.)

Como los fines y los modelos posibles son tan variados, hay muchos tipos de métodos. Ante todo, hay que distinguir entre métodos de investigación y de verificación. El primero de estos dos tipos se utiliza para hallar, descubrir, una solución. El segundo, en cambio, se ocupa de controlar (a posteriori) si esa solución es aceptable, legítima. Carnap ha distinguido tres etapas sucesivas:

-el encontrar («invención» de) una conclusión;

-la construcción (otra «invención») de una prueba que permita someter a verificación esa conclusión;

-el examen, control, mediante la prueba proporcionada de que tal conclusión es correcta. 
Aunque puede concebirse que haya métodos para cada una de estas etapas, en general resulta mucho más difícil determinarlos para las dos primeras que para la tercera. De ahí que Hans Reichenbach formulara la conocida distinción entre context of discovery (contexto de descubrimiento, de invención) y context of justification (contexto de Justificación: de validez, de fundamentación, de legitimidad). Para el primer «contexto», que correspondería a las dos etapas iniciales de las señaladas por Carnap, no parece que existan reglas susceptibles de sustituir la función humana de creatividad (inspiración, intuición); por tanto, ahí no caben métodos. No sería sino en el marco del segundo «contexto», pues, que los procedimientos podrían ser sometidos a un control metódico. ${ }^{6}$

Por otra parte, los métodos difieren según las especies de objetos encarados y también según los distintos tipos de conocimientos sobre esos objetos. Hay diferencias importantes entre los procedimientos aplicables en lógica formal y los de las ciencias de la naturaleza, o entre éstos y los medios a que recurren las ciencias sociales, etc. Y hasta en el interior de cada una de estas disciplinas, unos métodos pueden ser más adecuados para ciertos estudios, mientras que otros métodos serán preferibles para otros exámenes.

Cada rama de la ciencia, sea que se trate de ciencias «naturales» o de las «exactas» o de las que son llamadas «del espíritu» (o «del hombre»), posee sus propios métodos. No obstante, un mismo método puede, en su caso, ser aplicable en más de una ciencia, y también hay analogías entre métodos diferentes de disciplinas distintas. Estamos ante un pluralismo de métodos. Esto obliga a efectuar opciones, es decir, a elegir el o los métodos que sean aptos para las características de cada disciplina. E incluso entre los procedimientos que se aceptan en una disciplina dada, habrá que elegir aquel método que sea el más adecuado en vista del caso concreto.

${ }^{6}$ Para obtener la conclusión misma (1. ${ }^{\mathrm{a}}$ etapa) mediante un método, o para encontrar la prueba (2. ${ }^{\mathrm{a}}$ etapa) de la exactitud de tal conclusión por vías que sean propiamente metódicas, se tendría que disponer, en cada una de esas etapas, de lo que Carnap llamó un «procedimiento efectivo»: aquel que está sometido a reglas que pre-establecen, en forma unívoca y suficiente, todos los pasos necesarios para llegar, de manera indubitable, a la conclusión. Pero, en general, no se dispone de tal cosa, ni siquiera en las matemáticas. Incluso en éstas, la imaginación del investigador, su intuición, su «talento», desempeñan un papel fundamental en aquellas dos primeras etapas. Cfr. Horak, págs. 17 y sigs., y además Polya, passim; vid. también Frank, Law..., págs. 180 y sigs. (con referencias a Henri Poincaré, etc.). 
He querido comenzar por presentar una Idea muy general de lo que es «método». En los apartados que siguen se examina más de cerca los elementos esenciales de dicha noción.

\section{INTERSUBJETIVIDAD}

\section{a) Método y verdad}

Cuando el método va dirigido a la finalidad de conocer, él no es más que un medio para la búsqueda de una verdad, la cual constituye el fin al que se entiende dirigido el método en cuestión. Ahora bien, para apreciar si tal medio es adecuado, hay que tener una idea bastante precisa del género de verdad que se encara. No quiere decir, por supuesto, que ésta sea ya bien conocida de antemano, pues en tal caso no habría por qué efectuar tales investigaciones, esos métodos serían entonces superfluos; mas es necesario saber, sí, hacia dónde se dirige el interés de conocimiento que buscamos satisfacer por medio de ellos. En consecuencia, importa tener esto lo bastante claro como para poder distinguir bien la verdad que estamos persiguiendo de verdades que corresponden a otros dominios; y también para estar en condiciones de comprobar, ante los resultados obtenidos por la aplicación del método, en qué medida tal o cual afirmación particular, concreta, es «verdadera» respecto a esa esfera de estudios.

Pero, ¿qué es una «verdad»? Este término puede ser entendido en formas más amplias o más restringidas, y puede referirse a aspectos diversos. Por lo general, se dice que se trata de una adecuación del pensamiento a la cosa. ${ }^{7}$ Es eso lo que indica la fórmula clásica, veritas est adequatio rei et intellectus. Sin embargo,

\footnotetext{
${ }^{7}$ Prescindo de terminologías como las de Jaspers, Heidegger, Gadamer, etc., en donde la palabra «verdad» se usa en un sentido antes bien valorativo que descriptivo, que poco tiene que ver con su acepción habitual en las disciplinas científicas. Examino esto en un artículo donde critiqué, con cierto detalle, las posiciones centrales de Gadamer: «Hermeneutik contra Rechtswissenschaft» (Hermenéutica contra ciencia jurídica), en Archiv für Rechts-und Sozialphilosophie, vol. LXIV(1978), págs. 163-181 [algunas de estas críticas se recogen infra: Apéndice, punto 4]. Cfr, además las observaciones de Hubert Rottleuthner: «Hermeneutik und Jurisprudenz», en Hans-Joachim Koch (comp.), Juristische Methodenlehre und analytische Philosophic (Metodología jurídica y filosofía analítica), págs. 7-30, Athertäum, Königstein/Ts., 1976. [Vid. también la nota siguiente.]
} 
las diferencias se hacen sentir en cuanto nos preguntamos qué significan exactamente los tres términos relacionados en dicha fórmula: pensamiento, cosa, adecuación. Para lo que nos interesa aquí, basta con tener presente que el género de verdad que un método dado persigue, dependerá de la naturaleza de la «cosa» enfocada, y también de la especie de adecuación que se supone debe existir entre tal cosa y el pensamiento del investigador. En cuanto al método, lo que importa sobre todo es la manera de verificar si tal verdad se presenta o no en un caso dado. Y esto exige un buen nivel de precisión respecto a los pasos necesarios para controlar si realmente ese método alcanza o no, en sus aplicaciones concretas, los resultados que se persiguen, vale decir, el tipo de verdad buscado.

Para llegar a saber eso, es necesario ponerse de acuerdo sobre los criterios que permitan juzgar al respecto. Los criterios de la verdad que dominan en la ciencia contemporánea apuntan a la posibilidad de un control intersubjetivo. Inter-subjetividad (entre-sujetos-distintos) del conocimiento, esto es: que la verificación, el control en cuanto a la legitimidad de una afirmación, dependerá de criterios que sean firmes, en el sentido de que la gente -por lo menos los hombres de ciencia de la respectiva disciplina- estará habitualmente de acuerdo sobre la aplicación de dichos criterios, o sea, acerca del valor (grado de probabilidad, plausibilidad) de los resultados obtenidos en función de tales criterios. Para saber si es así, esos resultados deberán poder ser comunicados sin que haya, habitualmente, mayor riesgo de malentendidos. Ello exige, a su vez, el empleo de un lenguaje suficientemente riguroso, es decir, susceptible de ser entendido por lo general de modo unívoco, por lo menos en la comunicación que tiene lugar entre los especialistas de la disciplina de que se trate. Y todo eso es válido también para las ciencias del espíritu, en la medida en que ellas pretendan arribar a resultados objetivos. Quiere decir que la intersubjetividad de una ciencia consiste en:

(i) el hecho de disponer de un lenguaje riguroso, o sea, susceptible de ser generalmente entendido de manera inequívoca, al menos en la comunicación entre los especialistas de la disciplina respectiva;

(ii) el hecho de que los procedimientos y resultados de esa disciplina puedan ser expresados en forma adecuada, netamente comprensible mediante dicho lenguaje;

(iii) el hecho de que rija acuerdo (entre los especialistas) sobre el manejo de dichos lenguajes (i) y procedimientos 
(ii), y también sobre la legitimidad de los resultados (ii) que así se alcancen;

(IV) y todo ello con base en un cuerpo específico de conocimientos que caracterizan a esos especialistas como tales, el cual constituye el sistema teorético propio de la disciplina científica en cuestión.

«El conocimiento científico es, en primer lugar, el contenido, y sólo el contenido, que puede ser comunicado literalmente a otros mediante palabras entendidas literalmente, es decir, sin metáforas, analogías, etc., usadas en la transmisión del pensamiento. En segundo lugar, sólo pueden pretender ser reconocidas como conocimiento científico las afirmaciones acerca de las que cualquier persona que se encuentre en condiciones externas apropiadas pueda decidir sobre su corrección o incorrección. En otras palabras, el conocimiento científico es aquel que es intersubjetivamente comunicable y controlable. Es exactamente esta intersubjetividad lo que parece ser la característica del conocimiento racional.» (Kazimierz Ajdukiewicz, Introducción a la filosofía. Epistemología y metafísica, trad. de Alina Dlugobaska, Cátedra-Colección Teorema, Madrid, 1986, pág. 59.) Cf. también Brecht, págs. 119 y sigs., y cap. VII.3 (esp. el punto e).

En conclusión, no es posible ponerse de acuerdo sobre un método sin antes precisar los rasgos esenciales del tipo de verdad que se indaga. Mas, ¿cuándo podría decirse que esos rasgos se hallan bastante precisados? Sólo la práctica, en cada disciplina, puede proporcionar la respuesta. El tipo de verdad buscado está suficientemente determinado cuando, ante los resultados concretos de la aplicación del método, la generalidad de quienes reconocen la pertinencia de éste para los asuntos de que se trata, concuerdan asimismo acerca del grado de verdad que quepa reconocerle a esos resultados. Tal acuerdo, y que él sea comprobable a través de un lenguaje riguroso: eso, justamente, es la inter-subjetividad de una comunidad científica.

Lo dicho no significa, cabe aclarar, que todo criterio intersubjetivo ha de servir forzosamente para garantizar la verdad de las conclusiones alcanzadas o controladas por intermedio de él, ni tampoco que sea imposible alcanzar eventualmente verdades por vías que no son las de tipo científico. Empero, si por esas otras vías se llegara, acaso, a detectar ciertas verdades, la objetividad de éstas sería dudosa: como las opiniones están siempre divididas respecto a la legitimidad de tales «verdades» (por ejemplo, religiones, astrología, etc.), no es posible creer en ellas 
sino en virtud de posiciones bastante subjetivas y tal vez arbitrarias. La intersubjetividad no proporciona, por cierto, garantías absolutas para aquellas afirmaciones que la tienen como respaldo. No obstante, ella es el único medio de que disponemos para juzgar en forma menos arbitraria. ${ }^{7 a}$ De ahí que los conocimientos intersubjetivos se tengan por objetivamente verdaderos; aunque esto es siempre en forma provisoria, o sea, mientras no se pongan sobre el tapete unas razones nuevas -razones mejores, pero cuya justificación pueda, a su vez, ser intersubjetivamente probada- para rectificar algo que hasta entonces - jen adelante ya no!- era intersubjetivo. ${ }^{8}$ (Me refiero, más que nada, al tipo de intersubjetividad que es especialmente elaborada y rigurosa, la científica en sentido estricto: infra, VII y VIII.)

\section{INTERSUBJETIVIDAD}

b) Razonamiento y racionalidad, probabilidad (plausibilidad)

Dijimos que el método es un proceso esencialmente racional. ¿Qué significa esto? Por lo general, los autores subrayan que el pensamiento racional es una cosa distinta que los pensamientos

${ }^{7 a}$ «El motivo por el que el racionalismo valora sólo este tipo de conocimiento (el intersubjetivamente comunicable y controlable) es social (...) [L]a postura del racionalista es una reacción social sensata, es un acto de autodefensa de la sociedad contra los peligros de ser dominada por fuerzas incontrolables, entre las que se encontraría desde el santo que proclama una revelación hasta el loco que afirma los productos de su mente enferma, con el riesgo que supondría el poder de un individuo fraudulento que quisiera ganar seguidores para sus puntos de vista con el fin de llevar a cabo sus propósitos egoístas e indignos. Es mejor confiar en un seguro aunque modesto alimento de la razón, que, por temor a perder la 'verdad', dejarse alimentar con todo tipo de alimento incontrolable que, frecuentemente, resulta ser más ponzoñoso que saludable y benéfico» (Ajdukiewicz, ot). cit., págs. 59 у 62 ).

${ }^{8}$ Que esas nuevas razones sean en verdad «mejores», en el sentido de que constituyan realmente una mayor aproximación a la verdad -tesis del llamado racionalismo crítico, Popper, Albert, etc.-, es cosa discutible, sin embargo, desde unos puntos de vista como los sostenidos por Kuhn, Feyerabend, etc.: cfr. la discusión que contiene el volumen editado por Lakatos y Musgrave. De todos modos, la forma en que racionalidad y método se definen en el presente trabajo, nada prejuzga acerca de dicha cuestión. [A la idea de «verdad» me refiero con más extensión en un Excurso que incluí en el apartado VI de «Lo racional y lo razonable» (cit. supra, en la nota inicial: $x$ ). Para un tratamiento breve pero muy informativo sobre «El problema de la verdad», cfr. el capítulo que lleva ese nombre en el librito de Ajdukiewicz (op. cit.): Primera Parte, cap. II.] 
determinados simplemente por la vida emocional o por la costumbre. Sin embargo, en cuanto se trata de señalar en forma más específica qué es racional, las opiniones divergen.

Entre los múltiples sentidos que registra la palabra «racionalidad» (o «racional»: lo que es conforme a la «razón»), ${ }^{9}$ nos quedaremos, por su pertinencia para nuestro tema, con la acepción según la cual consiste en fundar las conclusiones sobre unos razonamientos cuya legitimidad es intersubjetivamente controlable. Por «razonamiento» entendemos, con Blanché (pág. 12), «un discurso tal que, estando puestas ciertas proposiciones y por el solo hecho de estarlo, otra proposición resulta de ellas, sea necesariamente, sea en forma más o menos probable». Se trata de un modo discursivo, es decir, la "expresión y desarrollo del pensamiento por una serie de palabras o de proposiciones que se encadenan» (Lalande, vocablo Discours); es, a diferencia de la intuición pura y simple, una manera mediata de llegar a la conclusión. ${ }^{10}$

El razonamiento consiste, pues, en un encadenamiento de proposiciones. Esa cadena reposa sobre intuiciones intelectuales que se refieren a relaciones de principio a consecuencia: hay algo que se sigue, que resulta, que se desprende, se infiere de otra cosa. Estas intuiciones, que permiten aprehender un vínculo entre la primera «cosa» (principio) y la segunda «cosa» (consecuencia), constituyen lo que Peirce llamó relación ilativa: cfr. Blanché, pág. 24 y sigs. El razonamiento puede consistir en un encadenamiento más o menos extenso y complejo de tales relaciones. Aquello que aparece como conclusión de una (primera) relación principio-consecuencia, a su vez puede servir como premisa a partir de la cual se desprende una nueva conclusión (segunda

${ }^{9}$ Las posibles definiciones de qué es «racionalidad» son, por supuesto, muchas y de lo más variadas, cfr. Haba, Rationalité. Por ejemplo, Priester (Rationalität und funktionale Analyse, págs. 61 y sigs.) ofrece una lista de 17 definiciones, las cuales se limita a recoger sólo entre las de la racionalidad llamada específicamente «formal» (sobre ésta, cfr. infra, el Excurso que contiene el apartado VI). Vid. también el artículo de Anacker. La ambigüedad de dicho término ya había sido advertida, desde luego, por Jhering, cfr. supra, en el acápite, e infra, nota 37. Particularmente sobre lo que es «racionalidad» en el derecho, cfr. los distintos enfoques que al respecto traen los trabajos reunidos en Archives de Philosophie du Droit, t. 23. [Vid. además infra, nota 17, sobre el término «razón».]

${ }^{10}$ «Se dice que una operación de pensamiento es discursiva cuando alcanza el fin al que ella tiende por una serie de operaciones parciales intermediarias» (Lalande, voz Discurs $\sim$ ). Según Blanché, «el razonamiento no aparece sino donde interviene una mediación» (pág. 14). 
relación principio-consecuencia), y así sucesivamente. Quiere decir que el razonamiento va de una premisa inicial (que corresponde a la primera relación principio-consecuencia) hasta una conclusión final (que corresponde a la última relación principio-consecuencia), pasando por una serie más o menos prolongada de escalones intermediarios (relaciones sucesivas de principio a consecuencia). Mas corresponde señalar (Blanché, págs 12 y sigs.) que como conclusión, en esa cadena, puede figurar ya sea el principio o la consecuencia de una de dichas relaciones, según que el razonamiento vaya orientado en un sentido o en otro, es decir, del principio a la consecuencia o a la inversa. A partir de un resultado ya conocido (consecuencias), puedo encontrar sus bases racionales (principios); o bien, inversamente, de unos principios extraigo cuáles son sus consecuencias. Por ejemplo, del articulado de unas leyes puedo remontarme a los principios generales de la institución jurídica respectiva, o bien, inversamente, de unos principios generales de derecho se pueden extraer consecuencias particulares; en el primer caso, la conclusión de ese razonamiento es un principio, mientras que en el segundo, la conclusión son unas consecuencias de ese principio. Ya sea que vaya dirigido en un sentido o en otro, lo peculiar de todo razonamiento es que en él la conclusión (sea un principio o una consecuencia) se infiere de las premisas (sean principios o consecuencias). En síntesis, puede decirse que: «Razonar es, pues, efectuar una inferencia o combinar inferencias.» (Blanché, pág. 15.)

Empero, hay razonamientos y razonamientos... Cualquier razonamiento constituye simplemente un medio. Es un camino intelectual orientado hacia una finalidad de conocimiento; inclusive lo es allí donde se trata de la determinación, por ese medio, de decisiones adecuadas con vistas a actuar: razonamiento práctico. La orientación de la cadena ilativa hacia el fin encarado, sirve para distinguir, según el grado en que ella sea apta para alcanzar verdaderamente ese fin, si dicho razonamiento es más o menos «bueno». Cada vez que decimos: puesto que..., entonces..., estamos ante un razonamiento, ${ }^{11}$ sea cual fuere su contenido. Claro que no todo razonamiento es correcto o la adecuación de un razonamiento se mide en función de la finalidad hacia la cual se le entiende dirigido, es decir, según que él logre o no alcanzar el conocimiento así buscado.

${ }^{11}$ Enlaces como: «en consecuencia», «por tanto», «de ahí que», «porque», «pues», «puesto que», «por ende», «por consiguiente», «dado que», «se sigue que», etc.; todas estas fórmulas son típicas para expresar razonamientos, ellas ponen de relieve el carácter de mediación que los caracteriza. 
El razonamiento presenta, pues, tres caracteres fundamentales: a) es un procedimiento de tipo discursivo, b) que descansa sobre unas relaciones ilativas, c) y se trata de un medio intelectual dirigido a una finalidad de conocimiento. Quiere decir que:

llamamos razonamiento a una cadena ilativa que, orientada hacia un fin de conocimiento, sea teorético o práctico, conduce desde unas premisas (principios o consecuencias) hacia una conclusión final (principio o consecuencia); esa cadena puede ser más o menos prolongada, y cada uno de sus eslabones puede tener una composición más o menos compleja.

Quedó agregado, al final de esta definición, que los eslabones de que se compone un razonamiento pueden ser, cada uno de ellos, más o menos complejos. En efecto, cada eslabón puede presentarse fundado, a su vez, sobre una cadena ilativa propia; y la cadena puede tener más de una premisa inicial, su punto de partida puede consistir en un conjunto de proposiciones; también el resultado final puede ser un conjunto de dos o más conclusiones. Por ejemplo, piénsese en un razonamiento tan complejo como el que representa, unitariamente, todo el cuerpo de una sentencia judicial. Pero esto no implica la necesidad de corregir el esquema propuesto, pues cada uno de esos conjuntos que configura un eslabón puede ser encarado formalmente como una unidad, o sea, como si se tratara de una premisa o de una conclusión, aunque esté compuesto en forma más o menos compleja. En rigor, un razonamiento (global) se halla a menudo integrado por varios sub-razonamientos (razonamientos subordinados), todos orientados hacia el fin de conocimiento principal, en función del cual ellos quedan ahí entrelazados. Sea que la cadena de un razonamiento esté más o esté menos complejamente integrada, ella presenta siempre los caracteres esenciales subrayados en la definición de razonamiento aquí ofrecida. ${ }^{12}$

Señalé qué caracteres formales definen lo que es un razonamiento. Ahora bien, no todo razonamiento es forzosamente racional. No basta con que un acto intelectual presente los tres

${ }^{12}$ Así, por ejemplo, incluso un esquema de argumentación como el que presenta Gottlieb (pág. 170), inspirado en el de Toulmin (pág. 104), puede caber en el marco de dicha definición. Y hasta se podría tomar como ejemplo de un razonamiento complejo los desarrollos del presente artículo, pues tratan de explicar y justificar la definición -ésta sería la conclusión- de método que se presenta al final (infra, X in fine). 
caracteres indicados para que, desde ya, haya ahí lo que hemos llamado «racionalidad» (cfr. al principio de este apartado). Al caracterizarla, subrayé que es intersubjetiva. Mas hay razonamientos que son poco intersubjetivos, por lo cual resulta que el carácter de racional no corresponde más que a un tipo de razonamientos: es el buen razonamiento intersubjetivo. (Recordemos que la «bondad» de un razonamiento es su aptitud para alcanzar un fin determinado.) Ello nos conduce a la siguiente definición:

llamamos racional a un razonamiento cuando él se asienta sobre a) cadenas ilativas intersubjetivamente controlables, b) orientadas hacia un fin de conocimiento compartido -de modo igualmente intersubjetivo- por los encargados de medir esa racionalidad, y en donde c) las conclusiones respectivas alcanzan -por lo menos en cierta medida, pero siempre intersubjetivamente- aquella finalidad. ${ }^{13}$

Más breve: una conclusión es racional cuando está fundada sobre razonamientos cuya legitimidad («bondad») es intersubjetivamente controlable.

La idea de racionalidad que he retenido constituye, ciertamente, un concepto estrecho de ella. Éste es el único apto para la construcción de métodos propiamente dichos. No obstante, hay autores que recurren a nociones más amplias de «racionalidad»; emplean ese término, o la palabra «razonable», para abarcar incluso unas vías de pensamiento distintas de las capaces de caber en el marco de la definición (estricta) aquí ofrecida. Es el caso, en especial, de unas corrientes hermeneutistas y de quienes se inspiran sobre todo en la Tópica y la Retórica aristotélicas: hermenéutica filosófica (Gadamer), nueva retórica (Perelman), tópica (Viehweg), tópica hermenéutica (Müller), metodología hermenéutica (Larenz), dialéctica aristotélica (Villey), controversia (Giuliani), argumentación jurídicamente razonable (Kriele), lógica de lo razonable (Recaséns), lógica de la elección (Gottlieb),

${ }^{13}$ Cuando decimos que las conclusiones racionales alcanzan el fin de conocimiento fijado, no hay que entender que llegarán siempre a ofrecer una respuesta positiva en cuanto a ese conocimiento que se persigue. De lo que se trata, por dicho medio, no es más que de obtener una respuesta adecuada (racionalmente) al problema planteado. Así, también es posible que tal respuesta sea negativa, si ese razonamiento permite comprobar (intersubjetivamente) que una hipótesis, la sometida a examen, no es correcta o que no está aún suficientemente probada. En tal caso, se llega racionalmente a saber que no se sabe. 
etc. Lo común a todas estas orientaciones es que ninguna de ellas señala unos criterios precisos para resolver las diferencias de opinión, es decir, para controlar intersubjetivamente esos razonamientos que ellos califican, así y todo, de «racionales» o «razonables» ${ }^{14}$ (más abajo se vuelve sobre esto, especialmente en el apartado VIII).

Ese concepto estrecho de racionalidad no implica que ésta tenga que ser una de tipo puramente lógico-formal o matemática. La racionalidad científica está lejos de agotarse en la sola esfera del razonamiento «constrictivo»: aquel que es válido -más aún: siempre y necesariamente válido- por sus solos trazos formales, el que corresponde a eso que Granger llama (págs. 57, 119, 123) la «razón constructora de máquinas». Habíamos visto, en cuanto al razonamiento, que éste no comprende sólo las inferencias necesarias, constrictivas, sino también aquellas que no son sino probables. Por eso, Polya llama la atención (cfr. la introducción de su libro) sobre la diferencia entre los razonamientos «demostrativo» y «plausible». También este último tipo aparece por doquier en las ciencias, incluso en matemáticas. ${ }^{15}$ Lo que hace «plausible» a un razonamiento es su buen grado de probabilidad. Y tratándose del pensamiento científico, ese grado es intersubjetivamente controlable: he ahí lo que distingue a la racionalidad propiamente dicha frente al campo de lo «razonable», entendiendo este último término de acuerdo con el sentido que le dan Perelman y otros. Nuestro concepto de racionalidad abarca, pues, tanto los razonamientos demostrativos como los probables, siempre que estos últimos sean intersubjetivos.

${ }^{14}$ Tal es asimismo el caso de los autores que subrayan la existencia de ciertos «cánones»o «elementos» en la interpretación jurídica, más allá de que los denominen o no «racionales», «método», etc.: Savigny, Coing, I.arenz, Fr. Müller, etc. Para una crítica de esta clase de posiciones, cfr. mi comentario a propósito de Betti: «Sur una 'méthodologie' de l'interprétation juridique», en Archives de Philosophie du Droit, t. XVIII (1973), págs. 371-383 (esp. págs. 378 y sigs.). En cierto sentido, esa crítica podría hacerse extensiva incluso a puntos de vista como los de Esser, quien se inspira (en alguna medida) en ideas de Gadamer: cfr. E. P. Haba, «Pré-compréhension et rationalité dans le travail du juge», en Archives de Philosophie du Droit, t. 20 (1975), págs. 385-400 (esp. págs. 396 y sigs.).

${ }^{15}$ Polya ofrece, en su libro, muchos ejemplos de aplicación del razonamiento plausible (inductivo) a los descubrimientos en matemáticas. Incluso muestra unos «patrones de inferencia plausible» (caps. XII y XIII) que muy bien se pueden aplicar asimismo en otros dominios, como el derecho; en cuanto a esto último, cfr. esp. el apartado 13 del cap. XIII (y vid. infra, nota 32). 
El género de probabilidad a que nos referimos aquí, no es la de tipo estadístico, puramente matemática, sino sobre todo la de carácter inductivo. En qué medida esta probabilidad podría ser vertida en fórmulas matemáticas, es un problema para el cual la teoría de la ciencia parece no haber hallado todavía una respuesta satisfactoria. Mas nosotros podemos desentendernos de tal dificultad, ya que en cuanto al tipo de intersubjetividad capaz de permitir el ponerse de acuerdo sobre un asunto de derecho, un grado tan extremo de precisión no suele ser indispensable, ahí basta con alcanzar una intersubjetividad no matemáticamente formulada.

Empero, los términos «probable» $\mathrm{y}$ «plausibilidad» son polisémicos. Podemos distinguir, por ejemplo, una probabilidad I (puramente estadística, matemática) de una probabilidad II (simple generalización, inducción), y una plausibilidad I (credibilidad respecto a hechos) de una plausibilidad II (axiológica, aceptabilidad de valoraciones). La probabilidad II y la plausibilidad I son la misma cosa; y es justamente tomándolos de acuerdo con esta acepción como nosotros utilizamos aquí ambos términos, como sinónimos. Eso no excluye, por supuesto, que tal «probabilidad» o «plausibilidad» pueda estar vinculada, llegado el caso, a probabilidades I o a plausibilidades II. ${ }^{16}$

En conclusión.- La racionalidad (propiamente dicha) no se agota en la lógica formal, el cálculo. Sin embargo, eso no quiere decir que abarque unos razonamientos que no son intersubjetivamente controlables: tópica, dialéctica, argumentación razonable, etc. La racionalidad comprende también conclusiones que sólo son probables, pero esto en la medida en que la plausibilidad de ellas sea susceptible de acreditarse ante un control intersubjetivo.

\section{DELIMITACIONES CONCEPTUALES}

He aquí unas precisiones sobre algunos conceptos básicos que estamos empleando.

${ }^{16}$ Cfr. Bochenski, núm. 21, sobre todo el primer parágrafo de ese apartado: Las dos significaciones de la palabra «probabilidad», en donde se dice:

«La primera clase de probabilidad se llama ordinariamente 'numérica', 'matemática' o 'estadística';la segunda, se llama 'aceptabilidad' o ‘credibilidad' (págs. 229 y sig. [trad.]). Sin embargo, no es seguro que el sentido que arriba se retiene para el término «plausibilidad» coincida exactamente con lo que Bochenski llama «aceptabilidad», aunque tal vezestán emparentados. Cfr. también Ströcker, págs. 31 y sig. 
Racionalidad y razón.- Para la palabra «racional», el Vocabulario Lalande dice: «Lo que pertenece a la razón o es conforme a ella...» Tal definición, aunque responde a usos habituales de dicho término, puede inducir a error. La idea de razón es algo muy confuso, o por lo menos ambiguo. ${ }^{17}$ Ella conduce a diluir las diferencias que existen entre lo racional, lo razonable, el razonamiento y en general cualquier intuición intelectual; estas formas pueden imputarse, todas ellas, a «la razón». La definición de racionalidad aquí propuesta (supra, a la altura de la nota 13), en cambio, es mucho menos genérica. Los sentidos que hemos retenido para esos términos, con la intención de marcar diferencias claras entre ellos al utilizarlos, corresponden a distinciones que importa subrayar, a cosas que no conviene confundir las unas con las otras. Si, por el contrario, lo «racional» se define como aquello que es, simplemente, conforme a la «razón» -vale decir, sin especificar que esta razón debe ser discursiva e intersubjetiva-, entonces resulta que, por ejemplo, podría haber racionalidad incluso allí donde ni siquiera estamos ante un razonamiento (falta la cadena discursiva, no hay mediación).

Racionalidad e intersubjetividad (intersubjetividades cientifica y no científica). -Vimos que la racionalidad implica intersubjetividad. No es verdad, en cambio, la afirmación inversa: que siempre haya racionalidad allí donde encontramos intersubjetividad. Existen también unos conocimientos intersubjetivos directos, inmediatos, esos que responden a una intuición (controlable) que no se siente la necesidad de basarla en ninguna otra cosa, pues aquélla parece ser evidente por sí misma. De tales conocimientos está llena la vida cotidiana: por ejemplo, cuando la gente reconoce, sin más, un color, una persona, una melodía,

${ }^{17}$ Cfr. Granger, Bobbio (La razón...) y Arnaud [respecto a este último, véase el punto 5 del Apéndice, infra.]. Por ejemplo, un autor como Jackson (Rationalité...) distingue los siguientes tipos de «razón» en cuanto al derecho: «La ciencia jurídica tiende a ver esta diversidad en los procesos de razonamiento en términos de fronteras disciplinarias. Una esfera queda delimitada en cuyo interior la disciplina del derecho es susceptible de ser objeto de procesos lógicos (lógica deóntica); la razón práctica se considera como una apertura del derecho a las cuestiones de filosofía moral y política; la razón inconsciente, si se entiende que ella tiene algo que ver, se le deja al antropólogo o al psicólogo» (pág. 2). «[C]uatro tipos distintos de la razón utilizada en el derecho han sido identificadas: la lógica clasificatoria, que gobierna las relaciones en el interior de conjuntos de conceptos o de instituciones jurídicas, hiponimia (hyponomie); la semiótica lógica (o lógica semántica), compatible con el desarrollo del cuadrado lógico; la semiótica discursiva, que incorpora el funcionamiento de reglas convencionales de clausura; y las asociaciones de categorías oposicionales binarias, que contribuyen a nuestros juicios intuitivos» (pág. 16). 
etc. Y también los hay en la actividad científica, aquellos que se desprenden de una observación primaria: los enunciados llamados «protocolarios», o por lo menos algunos de éstos. De ahí que pueda haber intesubjetividad sin que haya razonamiento, y, a fortiori, sin intervención de racionalidad ni método. Lo que diferencia a la intersubjetividad científica de la que no es tal, es que la primera se subordina al control de métodos, y que ella es de tipo sistemático (no se trata, en la ciencia, de unos conocimientos aislados o independientes entre sí), todo lo cual se maneja allí en función de unos marcos teoréticos explícitos y sofisticados (infra). Como dice Moreno (pág. 18): «En oposición al saber vulgar, la Ciencia es saber metódicamente fundado y sistematizado.» Intersubjetividad científica y método son, pues, inseparables. Pues ésta resulta, ella misma, de la aplicación de métodos, o bien consiste en el conocimiento de ciertos datos elementales que son lo suficientemente firmes y delimitados como para que a partir de ellos se pueda construir un saber metódico. En síntesis: la intersubjetividad puede ser científica o no científica, y sólo en el primer caso ella es siempre racional (si se trata de ciencia en sentido estricto). Por tanto, la noción de intersubjetividad está en relación de género a especie con la de racionalidad y la de ciencia.

Racionalidad y método.- Más atrás quedó señalada la diferencia entre razonamiento y racionalidad. También vimos que es su condición de racionales, en el sentido apuntado, lo que permite definir a los métodos propiamente dichos, científicos. Ahora bien, corresponde aclarar que no todo razonamiento racional constituye de por sí, necesariamente, un método (en dicho sentido). El método es siempre racional, pero lo racional no es siempre metódico. Cuando el pensamiento racional corresponde a un método, ese pensamiento se ajusta al marco de un plan intersubjetivo, o sea, queda sujeto a un sistema de reglas que son unívocas y fue preestablecido, un procedimiento estandarizado para alcanzar el fin perseguido. Quiere decir que racionalidad y método se hallan, también ellos, en relación de género a especie.

Método y ciencia.- Definiéndola en la forma más apretada, puede decirse que ciencia es: el saber teorético-sistemático, intersubjetivamente comunicable e intersubjetivamente controlable -un saber que, en la actualidad, suele ser muy complejo y sofisticado-. Según que dicha intersubjetividad sea la fuerte o una más débil, tendremos, respectivamente, ciencias en sentido estricto o en sentido amplio (infra, VIII: cfr. esp. el párrafo que termina en la nota 31 y al final de dicho apartado). La necesidad de método está comprendida en esa definición, pues este saber se 
exige que sea «controlable». Porque si el control ha de ser verdaderamente tal, tanto el de orden simplemente lógico (coherencia de lo teorético) como el de carácter empírico (contrastación por la experiencia, falsabilidad), tendrá que estar a cargo de métodos precisamente. Quiere decir que no hay ciencia sin método (cfr. la cita de Moreno, supra.) Pero ello no significa que ambos sean una y la misma cosa, estas dos palabras no son meros sinónimos. Una ciencia es más que sus métodos, porque: a) De ella forman parte también ciertos elementos teoréticos que son más discutibles, dado que no resultan estrictamente controlables por la aplicación de los métodos aceptados; pero esos elementos guardan, de todos modos, una plausible conexión teorético-sistemática con conocimientos (otros aspectos teoréticos) de esa ciencia que sí son controlables; y además, inclusive aquéllos son intersubjetivamente comunicables. b) Más aún, cabe señalar que en general los saberes de una ciencia no consisten en sus métodos simplemente; no es lo mismo un procedimiento de prueba -el medio («test») para llegar a la verificación o falsación- que lo así probado, aunque desde luego hay estrechas relaciones entre ambos extremos. Por otro lado, si se examina bien nuestra noción de método (supra, II), se apreciará que, definido así, puede haberlo hasta en procedimientos que emplean quienes no son científicos, pues en esa definición (ibid.) no se dice que quien aplica el procedimiento ha de tener asimismo el conocimiento teorético-sistemático respecto a lo que está haciendo. Por ejemplo, se suele aprender el método para manejar un automóvil o para usar una computadora, sin saber científicamente por qué eso funciona así, o puede decirse, inclusive, que una receta de cocina es el «método» para preparar determinado plato, que hace falta «método» para pescar, etc., ya que en todos esos casos hay un plan de conducta y un resultado intersubjetivos. Significa que es posible la aplicación de métodos sin que, en realidad, quien lo hace esté llevando a cabo una verdadera labor científica. Cabe distinguir entre método científico y método vulgar, llegado el caso. Ambos son intersubjetivos, tanto en lo que respecta a los pasos del procedimiento mismo como a la efectividad («bondad») de su resultado; pero el primero, a diferencia del segundo, forma parte de un conocimiento muchísimo más complejo, teorético-sistemático, y es aplicado en calidad de tal (supra). En conclusión: si hablamos de «método» sin hacer esa diferencia, resulta que método y ciencia son, como conceptos, círculos secantes; en cambio, si nos referimos sólo a métodos científicos, advertimos que éstos constituyen, respecto a la ciencia en general, sólo un aspecto -aunque fundamental- de ella, o sea, que 
el método no es más que parte de la ciencia (y esto, tanto, si los dos términos se toman en sentido estrecho como en sentido amplio: infra, VII in fine).

En cuanto a la idea de ciencia que aquí se presupone, cfr. la breve presentación ofrecida por Stegmüller (para no mencionar exámenes más pormenorizados, que el lector hallará por doquier) y el $\S 2$ de Horak; además vid. Atienza (Introducción...), 4.3 (esp. págs. 218-224), que resume otros elementos de la discusión -ideas de Kuhn, Feyerabend y Lakatos-, pero sobre los cuales no hay necesidad de pronunciarse en el marco del presente estudio (supra, nota 8).

Las precisiones efectuadas pueden hacerse gráficas de la manera siguiente:

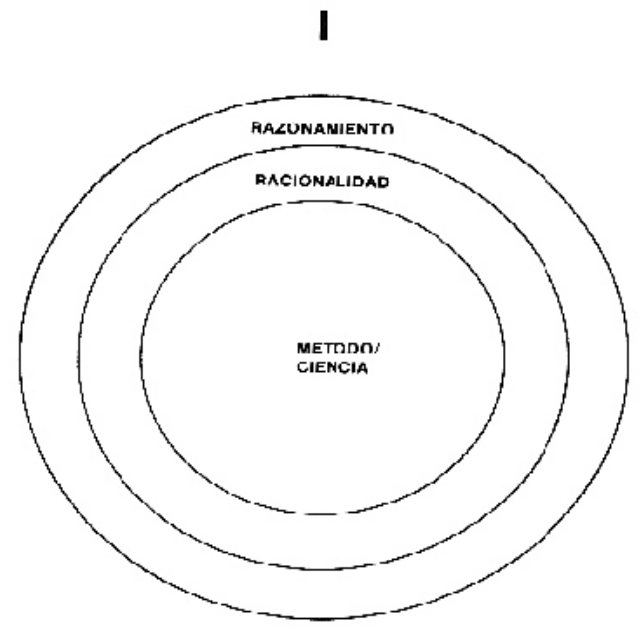




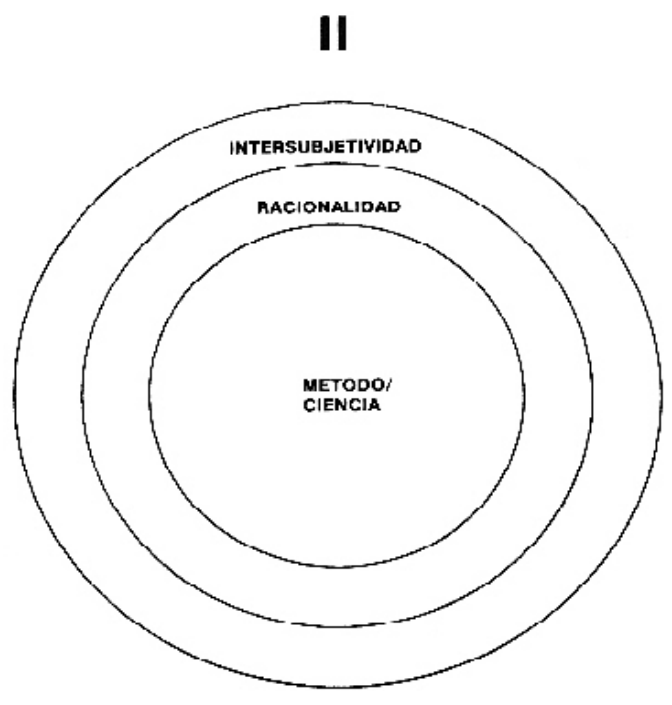

\section{III}

HACUNAMIEN 10 (pensamienio discursivo)

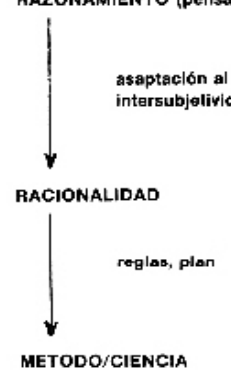




\section{IV}

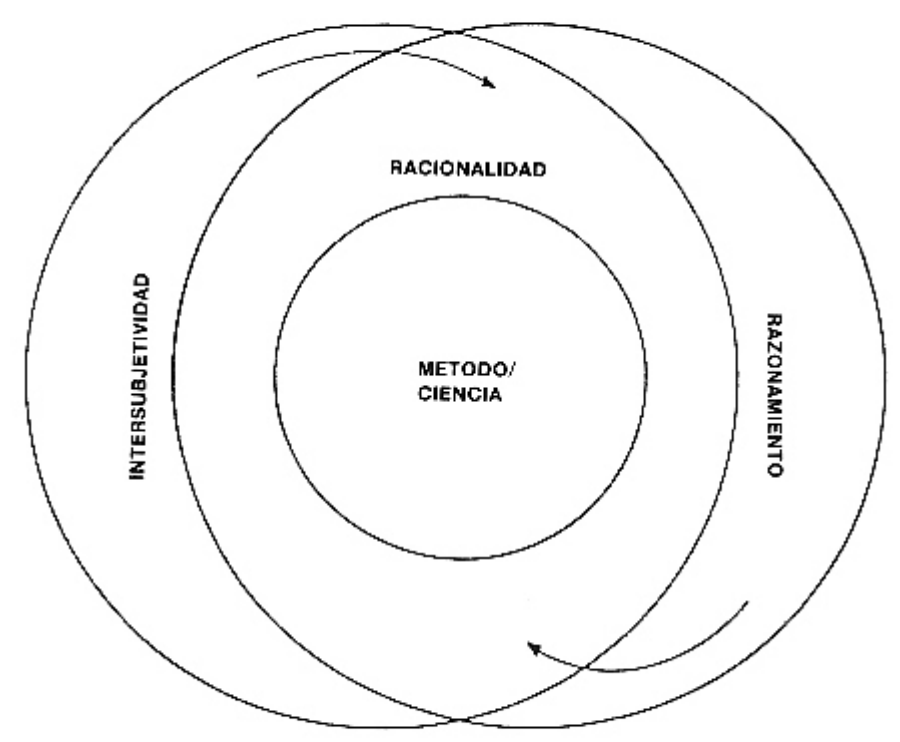

La figura IV representa una combinación de las liguras I y II; el esquema III equivale a la figura IV.

\section{LA CUESTIÓN DEL FUNDAMENTO: TIPOS, OPCIONES}

Cualquier razonamiento, y asimismo, por tanto, el empleo de métodos, tienen unos fundamentos. También este término es ambiguo. En sentido amplio, fundamento es la cadena entera de las relaciones de principio a consecuencia que preceden (desde el punto de vista lógico) a la conclusión final, es decir, todo el discurso que sirve para justificarla, todas las razones en que ésta se «basa»; pero en sentido estricto, el fundamento de un razonamiento no es sino su premisa inicial, no las restantes que se apoyan sobre la (o las) inicial(es) y que junto con ésta lleva(n) a 
la conclusión final. Por otro lado, se dice «fundamento», tanto para referirse al acto intelectual de fundamentar (punto de vista dinámico) como asimismo para señalar las ideas mismas utilizadas con ese fin (punto de vista estático). Nosotros tomamos ese término de acuerdo con su sentido estricto y estático; no obstante, incluso si la palabra se entendiera en sentido amplio y según el punto de vista dinámico, eso no conllevaría diferencias importantes para lo que aquí se quiere explicar.

Este término es polisémico también en otros respectos. ${ }^{18}$ Por ejemplo, se dice «fundamento» para hacer referencia a un principio, o sea, en el sentido de un punto de partida lógico del cual se puede deducir -lógica constrictiva- ciertas consecuencias. $\mathrm{O}$ se le encara como razón de un conocimiento, como aquello que está en condiciones de justificar la verdad de un juicio; y éste aparece, entonces, ya sea como apoyado en la verdad de otro juicio admitida de antemano, ya sea como sostenido por un recurso directo a la evidencia de la situación de hecho afirmada. O puede tratarse de una causa eficiente, la razón de un devenir, aquello que va a producir ciertos acontecimientos (efectos) en la realidad. O bien, en fin, se alude a la razón de ser de una cosa, a su «esencia»-fundamento ontológico-, indagación que se dirige a un sentido de tipo metafísico. Por lo demás, no sólo se discute si tiene fundamento un juicio, sino que también se dice que la legitimidad de conductas ha de estar debidamente fundada; sin embargo, en este último caso no son los actos mismos los que tendrán un fundamento, sino que éste pertenece, en rigor, a la opinión según la cual esos actos están justificados.

Pienso que, por lo que hace al razonamiento de los juristas, basta con atender al papel que allí juegan tres tipos principales de fundamentos:

-enunciados que contienen una afirmación de hechos;

-juicios de valor;

-proposiciones que se toman como axiomas, sea cual fuere su contenido, ${ }^{19}$ para servir como base de deducciones estrictas.

(También puede haber, desde luego, premisas que contengan

${ }^{18}$ Cfr. Lalande (voz Fondement) y sobre todo Röd (passim).

${ }^{19}$ Como contenido referencial de tales proposiciones podría caber incluso un hecho o una valoración, pero entonces tomados (ahí) como axiomas, o sea, no en tanto que afirmación de hechos o de un valor en cuanto tal. 
una combinación entre afirmaciones sobre hechos y valoraciones, incluso como base de la cadena ilativa.)

Por tanto, las relaciones de principio a consecuencia que se entienden dadas en función de tales juicios, presuponen respectivamente tres tipos de fundamentos:

-Según una dirección de sentido fáctico (relación de causa a efecto o de medio a fin, probabilidad): el fundamento es una causa o un fin, lo fundamentado es (respectivamente) un efecto o un medio. ${ }^{20}$

-Según una dirección axiológica (vínculo de valor, fines en cuanto valores, jerarquía valorativa): el fundamento es un valor o la valoración de una cosa, lo fundamentado es el valor de algo que de cierta manera corresponde a aquello otro. ${ }^{21}$

-Según una dirección puramente lógico-formal (deducción estricta, inferencia constrictiva): el fundamento son aquellas premisas de las cuales la conclusión, así fundamentada, se pueda deducir mediante la mera razón formal. ${ }^{22}$

\footnotetext{
${ }^{20}$ Esto es: el fundamento (A) de cierta cosa (B), ahí está dado por algo (A) que en la realidad sirve para ocasionar $(\mathrm{A}=$ causa $)$ aquella cosa $(\mathrm{B})$, o algo que podría ser alcanzado $(\mathrm{A}=$ fin) por medio de ella (B). [Aclaración: aunque a B le llamamos «cosa» y a A lo calificamos simplemente de «algo», eso no quiere decir que A no pueda ser tan «cosa» como B. Esta aclaración vale también para las dos notas que siguen.]
}

${ }^{21}$ Esto es: el fundamento (A) de cierta cosa (B, que es valiosa), ahí está dado por algo (A: un valor propiamente dicho, o lo que se tenga por una encarnación -más o menos adecuada- de ese valor, o en general lo que son valoraciones) tal que aquella cosa (B) pueda considerarse que en cierta manera corresponde a este «algo» (A). [Acotación: en verdad, sería mejor decir siempre valoraciones en vez de «valores», lo cual evita incurrir en un prejuzgamiento (implícito) respecto a la naturaleza ontológica de tales fenómenos de la conciencia; si nos referimos simplemente a «valoraciones», nada decimos, ni a favor ni en contra, sobre si a ellas corresponden o no, como correlato objetivo, unos entes (valores) que realmente tengan existencia propia más allá de la subjetividad de quienes efectúan esas valoraciones -discusión filosófica acerca del carácter subjetivo u objetivo, relativo o absoluto, de los llamados «valores»-.]

${ }^{22}$ Esto es: el fundamento (A) de cierta cosa (B: conclusio), ahí está dado por algo (A: premisas) de donde aquella cosa (B) puede ser deducida por la razón formal; tanto A como B son en sí mismos, aquí, unas formaciones lingüísticas, y pueden referirse ya sea a objetos reales o ideales, o incluso a cosas imaginarias. [Aclaración: también en los casos contemplados en las dos notas anteriores tenemos que vérnoslas con unas «formaciones lingüísticas», precisamente aquellas mediante las cuales se formulan tales razonamientos; pero allí, a diferencia del tipo de razonamientos a que corresponde esta nota, dichas expresiones lingüísticas se refieren necesariamente a unos datos que -según se entiende- 
Es obvio que según cual sea el tipo de fundamento tomado en cuenta, el género de relación ilativa considerado es distinto, la conclusión estará fundamentada (justificada) de otra manera. Empero, cabe reiterarlo, a menudo esos tipos aparecen combinados en un mismo razonamiento. Por ejemplo: partiendo de un juicio de valor, el pensamiento que se dirige a la realización de ese valor querrá ser no-contradictorio (implicación lógica) y deberá tener en cuenta también circunstancias de la realidad (facticidad).

Excurso: racionalidad teleológica (racionalidad «formal»).- Entre los tipos que se acaban de indicar no aparecen mencionados de modo expreso, por su nombre, los fundamentos de carácter teleológico: fines, objetivos, metas. Es porque tales fundamentos caben, según la manera en que sean encarados, ya sea entre los de tipo axiológico o bien entre los que enuncian cuestiones de hecho (unas relaciones de causa a efecto). Cuando de lo que se trata es de saber si algo debe o no ser admitido como finalidad, o como encarnación de un fin, el punto en examen es cual sea el valor (valoración) que corresponde aceptar para ese «algo» (la cosa examinada). Si, en cambio, de antemano se enfoca tal o cual cosa, ya como un fin (sea bueno o malo), y si la pregunta es sólo cuáles son los medios prácticos para realizar dicha finalidad presupuesta, entonces el razonamiento aplicable persigue una dirección que es meramente la de obtener información sobre datos de orden fáctico; no se trata, ahí, más que de conocer las causas eficientes capaces de tener como efecto los fines del caso, con vistas a poner en juego (o a evitar) dichas causas para alcanzar (o evitar) tales objetivos. Quiere decir que, en definitiva, la racionalidad de carácter teleológico puede siempre ser reconducida a fundamentos de tipo axiológico o fáctico. En la terminología de Max Weber, a estos dos tipos corresponden respectivamente la racionalidad material y la racionalidad formal: la primera, racional con arreglo a valores -Wertrationalität-; la segunda, racional con arreglo a fines -Zweckrationalität-. Si se usa tal terminología, la racionalidad llamada «formal» no sería sino una de las especies que caben dentro del concepto general presentado más arriba (ver a la altura de nota 13; y cfr. también la nota 9). Sin embargo, también ese concepto general es, bien mirado, sólo una definición formal de la racionalidad, todo él, ya que no ofrece criterios de contenido: no especifica

están más allá de ellas, de modo que entonces el fundamento y lo fundamentado no son, en sí mismos, aquellas expresiones sino esos datos (extralingüísticos) de que éstas hablan.] 
cuáles son las cadenas ilativas en cuestión, ni cuál es el fin de conocimiento perseguido, ni cuáles son las conclusiones así obtenidas; sólo indica un cierto orden de relaciones entre estos tres aspectos, en un marco global de intersubjetividad. Así, aunque nuestra definición general de «racionalidad» es toda formal, en su interior caben distintas clases de ella, según los respectivos fundamentos. Y una de esas clases es la forma de racionalidad teleológica que se conoce especificamente bajo el nombre de «racionalidad formal», cuando estos dos términos son tomados en su acepción más restringida.

El exigir que se dé un fundamento constituye la esencia misma del pensamiento racional, e inclusive del que simplemente quiere ser razonable. La cuestión del fundamento surge por el hecho de pedir un «por qué» para un juicio. Ese «por qué» puede, como acabamos de ver, ser entendido de distintas maneras, pero la respuestas siempre será, en definitiva, algún otro juicio (fundamento) que se refiera a tal o cual cosa. También es posible no darse por satisfecho con dicha respuesta, o sea, pedir incluso un «por qué» respecto a ese segundo juicio: un fundamento (II) para aquello que en la primera respuesta se propuso como fundamento (I), esto es, preguntar por un fundamento del fundamento. O hasta cabe que alguien requiera un fundamento (III) para el fundamento (II); y así sucesivamente, hasta el infinito. La cadena de los fundamentos -fundamentos de fundamentos- es virtualmente inagotable.

Por tal virtualidad, el punto de partida de todo razonamiento constituye, de hecho, una ruptura en la cadena de los fundamentos posibles. El razonamiento se detiene allí en el fundamento $n$, aceptándolo como suficiente, a pesar de que resulta siempre posible (hipotéticamente) pedir que se proporcione todavía un fundamento $\mathrm{n}+1$ para considerar aceptable $n$. Por otra parte, asimismo es cierto que una conclusión puede ser fundamentada de modos diferentes, mediante distintas cadenas de razonamientos, aun entre las del mismo tipo. Por ejemplo: un hecho puede tener varias causas, de las cuales sólo algunas son conocidas o mencionadas; una conducta puede ser justificada en función de distintos criterios de valor, etc.

Por ende, el hecho de elegir un fundamento determinado, de apoyar una conclusión sobre un razonamiento dado, siempre comporta cierto grado de arbitrariedad: ¿por qué tomar como base el fundamento A en vez del fundamento B? En última instancia, 
esa elección se remite a un consenso. Se piensa que es legítimo -que tiene el carácter de indiscutido e indiscutible- el fundamento elegido, porque se está (o se cree que hay que estar) de acuerdo en cuanto a él. ${ }^{23} \mathrm{Y}$ este acuerdo responde a la finalidad, sea de conocimiento o práctica, perseguida mediante el método correspondiente. Así, por ejemplo, la posibilidad de alcanzar una interpretación metódica de las leyes, suponiendo que tal cosa sea viable, dependerá del hecho de elegir para ella unos fundamentos bastante intersubjetivos. $^{24}$

En conclusión: cualquier método se basa en ciertos fundamentos, y éstos son el resultado de una opción que depende del fin de conocimiento que se persiga mediante la aplicación de dicho método. A menudo esta elección se produce de manera más o menos inconsciente, lo cual sucede sobre todo cuando esos fundamentos se presentan como verdades que parecen obvias, o sea, como unas pre-comprensiones respecto a las cuales no se advierte siquiera que son tales. No obstante, aun entonces estamos en presencia de una opción, aunque sea tácita, ya que siempre sigue siendo posible (hipotéticamente) preferir un fundamento distinto y cambiar de método.

\footnotetext{
${ }^{23}$ No tenemos necesidad de interrogarnos aquí sobre la manera en que dicho consenso consigue establecerse, ni acerca de las condiciones en que pueda ser revisado (cosa que varía de un dominio a otro). Todo ello depende de múltiples circunstancias empíricas: técnico-científicas, psicológicas, sociológicas, etc. (cfr., por ejemplo, los distintos puntos de vista expuestos en Lakatos/-Musgrave). Lo que arriba se subraya, son simplemente algunos rasgos de la estructura de la racionalidad en general, aspectos que pueden ser aplicables también al derecho. En cuanto al carácter siempre provisorio que, para una «racionalidad crítica», tiene cualquier fundamento -y, por ende, también los razonamientos y conclusiones basados en éste-, cfr. los trabajos de Albert.

${ }^{24}$ Ésa es, precisamente, la idea central de la Tesis en que se origina este estudio [cfr. supra, la nota inicial: $\left({ }^{*}\right)$ ]. Y a dicha idea respondía también un trabajo mío anterior, donde presento un cuadro general de figuras tradicionales del pensamiento jurídico, tratando de señalar sus respectivos presupuestos racionales: Esquemas metodológicos en la interpretación del derecho escrito. La versión más detallada de esa idea, como principio heurístico, es mi estudio: «Apuntes sobre el lenguaje jurídico (III): Alternativas para el intérprete», en Revista de Ciencias Jurídicas, núm. 39 (septiembre-diciembre, 1979), págs. 153-258, Universidad de Costa Rica-Facultad de Derecho/Colegio de Abogados, San José.
} 


\section{EL «CÍRCULO» DE LA INTERSUBJETIVIDAD METÓDICA. CONDICIONES ESENCIALES DE LA RACIONALIDAD QUE CARACTERIZA A LOS MÉTODOS PROPIAMENTE DICHOS}

La intersubjetividad puede alcanzar a un sector más o menos amplio de personas, y en cada disciplina no se refiere más que a tales o cuales aspectos de los objetos. Si tenemos en cuenta esas limitaciones, como así también el carácter relativo de todos los fundamentos, es evidente que no existe la racionalidad o el método, sino únicamente unas formas racionales y unos métodos, pues aquellas y estos son tales sólo para un género de casos y para un círculo dado de gentes. Este círculo podría acaso, potencialmente, abarcar a la humanidad entera, pero en la práctica se trata, por lo general, de grupos mucho más restringidos: un pueblo, una colectividad religiosa o política, un sector profesional, los aficionados a cierto deporte o a determinado género artístico, etc. En el caso de las ciencias, se trata siempre de unos métodos-para, racionalidad dentro de un grupo de expertos, o por lo menos de conocedores.

Hay método, pues, allí donde la legitimidad de los pasos que integran ese procedimiento estandarizado se reconoce intersubjetivamente en el círculo que lo emplea, piensen lo que piensen (o aunque no lleguen a pensar nada) al respecto cualesquiera otras personas. Basta con que el razonamiento que sirve para conformar el método pueda ser seguido en forma análoga y disponga de igual fuerza ilativa en el interior de dicho grupo, es decir, para los especialistas de la disciplina en cuestión. ${ }^{25}$ Eso no quita, por supuesto, que una persona pueda pertenecer a más de uno de dichos círculos y que estos puedan ser más amplios o menos amplios. Los círculos se entrecruzan, ya que lo que determina cuál será la extensión de cada uno, quienes forman parte de él,

\footnotetext{
${ }^{25}$ La intersubjetividad de los procedimientos metódicos ha de poder alcanzar en principio a todos los miembros del círculo. Sin embargo, podría entenderse que incluso se tengan allí por válidos, desde el punto de vista metodológico, ciertos resultados que sólo la amplia mayoría del círculo acepte, aunque una minoría de él los cuestione; pero esto, nada más que para algunos casos excepcionales que en el círculo se reconocen como discutibles (o sea, cuando la mayoría misma admite, al respecto, que la opinión discrepante de una minoría no es absurda en relación con el método aceptado por todos). Si no fuera así, si los procedimientos ya no estuvieran en condiciones de producir habitualmente un acuerdo general dentro del círculo, entonces no constituyen un método propiamente dicho; en el mejor de los casos, podrían entonces ser método en sentido amplio, unas vías para lo razonable y no de lo racional (infra, VIII).
} 
no es otra cosa que el poseer los conocimientos de la disciplina respectiva. Conviene aclarar que la expresión «círculo» o «grupo», tomada en tal sentido, no implica la necesidad de que haya alguna organización de tipo institucional (con autoridades, reglamentos, etc.) en que se unan sus miembros, y ni siquiera suele ocurrir que todos ellos se conozcan de alguna manera entre sí, sino que se trata, simplemente, de una vinculación de hecho en el plano intelectual: compartir determinados conocimientos, la posibilidad de que sus miembros se entiendan unos con otros -jintersubjetividad!- en la eventualidad de que lleguen a entablar un diálogo al respecto.

En función de todo lo señalado, resulta que lo racional admite gradaciones. El grado de la racionalidad depende de tres condiciones esenciales:

a) determinación del círculo de personas a las que se considera capacitadas para juzgar sobre la legitimidad de los razonamientos en cuestión, es decir, poder distinguir netamente quiénes son los individuos que deben estar de acuerdo -o cuando menos no estar en desacuerdo- para que ahí haya intersubjetividad, ${ }^{26}$

b) precisión de los aspectos respecto a los cuales ha de producirse ese acuerdo; ${ }^{27}$

c) indicación de un verdadero procedimiento de control, esto es, de los medios intelectuales concretos que hay que aplicar, llegado el caso, para comprobar, de manera unívoca, que allí la intersubjetividad existe efectivamente entre los sujetos que deseen efectuar tal control y que ella se refiere en realidad a los aspectos relevantes.

Para saber en qué medida estas condiciones se cumplen respecto a un procedimiento dado, o sea, cuál es su grado de racionalidad, no es sino la práctica misma de dicho procedimiento la que puede proporcionar la respuesta. Estamos ante un método propiamente dicho, si las tres condiciones resultan estar, de hecho, lo suficientemente precisadas como para que los equívocos

\footnotetext{
${ }^{26}$ El círculo de personas para las que un conocimiento racional es intersubjetivo, en una hipótesis límite podría estar integrado por sólo dos individuos, siempre y cuando éstos coincidan en forma general respecto a la apreciación de los resultados de determinados procedimientos. Mas podemos prescindir de tal hipótesis, ya que las discusiones sobre métodos no se refieren nunca a ejemplos tan extremos. Aquí pensamos sobre todo en «círculos» de tipo profesional, o, en general, los de gentes (muchos) que comparten cierta formación intelectual.
}

${ }^{27}$ Por ejemplo, si el objeto de conocimiento es la conducta humana, ésta puede ser enfocada desde distintos puntos de vista: moral, derecho, resultados meramente útiles, etcétera. 
acerca de la existencia efectiva de intersubjetividad se encuentren descartados en la mayoría de los casos para los cuales ese método debe ofrecer una solución aceptable. He ahí el tipo de racionalidad que caracteriza a los métodos científicos.

Agrego dos precisiones. 1) El no reconocer como «válida», para juzgar acerca de la aplicación de un método, sino la opinión que emana de un círculo de especialistas, no es otra cosa que una comprobación realista sobre cómo funciona el discurso científico: puesto que la aplicación del método exige que se conozcan sus reglas racionales, o por lo menos una parte de ellas, eso queda, en general, sólo en manos de quienes han efectuado estudios de la disciplina respectiva. 2) Al decir que se trata de intersubjetividad metódica -no, pues, de una intersubjetividad cualquiera- ${ }^{28}$ con eso se subraya que es esencial, para que la haya, que en el «círculo» sea posible ponerse de acuerdo precisamente sobre las soluciones concretas obtenidas por la aplicación (en cada caso) de ese método.

\section{LO RACIONAL Y LO RAZONABLE}

\section{a) Cuatro planos del pensamiento}

Cabe distinguir, teniendo en cuenta los desarrollos precedentes, cuatro planos del

I. pensamiento:razonamiento lógico-formal, constrictivo en el más alto grado

II. razonamiento sólo plausible pero intersubjetivamente controlable

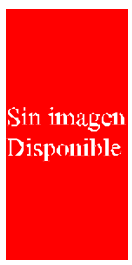

racionalidad, posibilidad de método

${ }^{28}$ Recuérdese lo señalado más atrás, al comienzo del presente apartado: la intersubjetividad puede ser tal en mayor o menor grado, ser científica o no científica, etc. Véase también supra, en el apartado $\mathrm{V}$, el párrafo «Racionalidad e intersubjetividad». 
III. razonamiento sólo razonable, plausible pero no intersubjetivamente controlable

IV. «razonamiento privado», simple «lógica de los sentimientos» o intuición puramente personal

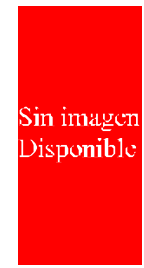

sin posibilidad de método (propiamente dicho)

Para el derecho, en la medida en que pueda ser objeto de discursos verdaderamente metódicos, sobre todo importaría lo que a él se pueda integrar del plano II. Aquí hemos estado usando las palabras «racionalidad» $\mathrm{y}$ «racional» de acuerdo con este último sentido, estricto; quiere decir que, para nosotros, el grado de racionalidad del derecho dependería, justamente, de la medida en que ese tipo de razonamientos se dé en el discurso de sus operadores. Otros, en cambio, opinan que son principalmente unos razonamientos del tipo III los típicos del pensamiento jurídico; y esto, tanto respecto a lo que el derecho ya es (su práctica, tal y como ella se da efectivamente en la realidad, y también su doctrina científica dominante, su dogmática), como asimismo en cuanto a lo que él pueda y deba ser. Este punto de vista, compartido por todos aquellos que pregonan la «tópica», la «dialéctica», la «argumentación», la «hermenéutica», etc., pone todo su énfasis en lo que puede llamarse: el plano de lo razonable.

Los partidarios de estas últimas posiciones subrayan que el razonamiento jurídico, y en general las «ciencias del espíritu», no pertenecen al dominio de los razonamientos que son lógicamente constrictivos, sino al de lo simplemente probable. Es el campo de lo plausible, del más-o-menos, de lo fuerte y lo débil, de una «balanza» de argumentos: cuestión de un «arte», más bien que de métodos... Así, ellos suelen plantear las cosas de manera tal que la problemática parece quedar confinada a la alternativa siguiente: dado que los razonamientos moral, jurídico, etc., no pueden caber en el plano I, no quedaría ninguna otra salida, si no queremos que sean abandonados a lo irracional (plano IV), que reconocerles una clase de racionalidad que les es propia, lo «razonable». Y de ahí que cuando esos autores emplean la palabra «método», lo hacen tomándola de acuerdo con unos sentidos muy amplios. ${ }^{29}$

${ }^{29}$ Las razones que se acaban de recoger son, sobre todo, aquello en que más insiste Perelman (cfr. también infra, el punto 2 del Apéndice). Otros autores 
No voy a discutir que se le puede llamar «racional» hasta a tal tipo de pensamiento, o a cualquier otra cosa, ni examinaré aquí si él difiere verdaderamente, en el fondo, de lo que pueda ofrecer el plano IV, el de la irracionalidad (o, en todo caso, una no-racionalidad; cfr. infra, la nota 36). Basta con subrayar, una vez más, que no es por pertenecer al campo de lo probable que lo razonable se distingue de lo racional, sino por el carácter intersubjetivo de los criterios de probabilidad que se aplican para apreciar la legitimidad de los razonamientos de este último tipo. En el campo de lo probable tiene cabida, además de lo razonable, también la plausibilidad de lo racional. Por tanto, el modo en que los topicistas, hermeneutistas, etc., muestran las cosas plantea una falsa alternativa. Porque entre los planos I y IV no está sólo el plano III, ;sino también el plano II! Y justamente este último es el que podría alcanzar la mayor importancia en el derecho. Los alegatos en favor de lo razonable disimulan la existencia del plano II, pues no discuten sino las posibilidades de los planos restantes, en especial para subrayar que la disyuntiva de lo viable se agotaría en una opción entre el III y el IV.

En el plano II, la plausibilidad (o la falta de plausibilidad) de las conclusiones obtenidas se encuentra unívocamente reconocida por los miembros del «círculo» que examinen el caso de que se trate. En cambio, respecto a lo que es sólo razonable, lo común es que, en el interior mismo de un círculo dado, unos consideren que es A y otros que no-A es lo más plausible. No obstante, podría decirse que lo razonable ofrece, así y todo, cierta intersubjetividad, algún grado de acuerdo, ya que se trata de unas razones que las reconocen como legítimas distintas personas. A los ojos de éstas, que pueden formar parte de un «círculo», tales razones se presentan justamente como «razonables», o

-Gadamer y Habermas, por ejemplo- presentan las cosas de manera, puede decirse, menos «laica», se valen de unos marcos de referencia más bien románticos o utópicos. En cuanto a la idea de «método» en sentido amplio, cfr. la nota 2, supra, y lo que dice Larenz (pág. 507): «El término 'método', tal como es entendido en este libro, quiere decir un procedimiento ordenado de pensamiento, que se lleva a cabo con ciertos pasos, sin que sea preciso ciertamente que entre ellos exista una conexión de derivación lógicamente obligante. Pero, como quiera que en otras ciencias se exige una tal conexión, fácilmente se enlaza a la palabra «método» la idea de que esa conexión se presupone aquí, y esto puede ser una de las razones de que recientemente más de uno prefiera la expresión 'Teoría de la argumentación' al término 'Metodología'. Aquélla suena a incompromiso, especialmente si se enlaza con la palabra clave «Retórica», y afecta sobre todo al procedimiento ante un tribunal.» [Sobre Perelman, cfr. Blanché (cap. XIV) y Villey (Nouvelle...). Además vid. la nota 31, infra.] 
inclusive como «racionales». Pero, a diferencia del razonamiento racional, los argumentos razonables no resultan igualmente plausibles para la generalidad de los que pertenecen al círculo en cuestión. Más: en la mayoría de esos casos, el círculo no está ni siquiera bien delimitado como tal, sus fronteras son muy indeterminadas. Para una racionalidad, en cambio, el círculo respectivo está pre-establecido, se determina en función de criterios de selección bastante claros, sobre todo el de la especialización profesional. No pasa así con el círculo de quienes puedan suscribir los argumentos simplemente razonables. No se llega a fijar quiénes son los miembros de este círculo sino en el momento mismo en que se pueda comprobar cuáles son las Personas que están actualmente de acuerdo con dichos argumentos, lo cual es imposible saber de antemano. Además, aunque se dé por sentado que estos argumentos son para un «auditorio» muchísimo más amplio que el recuento de aquellas personas que de hecho llegan a conocerlos y aceptarlos, lo cierto es que nadie puede saber si tales o cuales individuos estarían en realidad de acuerdo en formar parte de ese auditorio (ampliado); de ahí que, en definitiva, el círculo no estará nunca bien delimitado, y ni siquiera a posteriori. La apreciación sobre el carácter más o menos razonable de una argumentación de ese tipo queda remitida, así, al juicio de no se sabe exactamente quién o quiénes: por ejemplo, al «auditorio universal» de que nos habla Perelman, ${ }^{30}$ o a la situación «ideal» (trascendental, ipero contrafáctica!) de comunicación que nos pintan Apel y Habermas.

Con lo dicho, no pretendo negar que hay diferencia entre lo razonable y lo irracional (infra, nota 36). Pues lo razonable tiene, a pesar de todo, cierta intersubjetividad, como ya señalé. En efecto, lo que sea razonable es algo que, para ser tal, debe no carecer por completo de intersubjetividad, si tomamos este término en sentido amplio (supra, nota 28). Empero, a diferencia de lo racional, ésa es una intersubjetividad débil, la de un círculo con fronteras muy indefinidas. Esta intersubjetividad sirve, de todos modos, para marcar una diferencia importante entre lo razonable y los razonamientos puramente subjetivos, así como frente a lo irracional en general. Los desacuerdos sobre qué sea, en su caso, más razonable o menos razonable, no impiden que

${ }^{30}$ En otros sitios he presentado observaciones críticas más detalladas acerca de ese tipo de posiciones: cfr. los estudios mencionados en las notas 7 y 14, supra, y sobre todo (en cuanto al punto específico que se discute arriba: círculos, auditorios) mi artículo Rationalität der Autoritäten... Vid. también la nota siguiente. 
quienes opinan al respecto puedan tal vez estar de acuerdo por lo menos, todos o casi todos ellos, en reconocer que las soluciones en torno a las cuales se discute son relativamente aceptables, unas y otras: que ellas no son puramente absurdas, irracionales. Las discrepancias allí no se referirían, pues, al carácter genéricamente razonable de las razones discutidas, sino sólo al grado, a la medida en que éstas son (más o menos) aceptables, ellas tendrían todas, para todos los que forman parte del círculo, un mínimo de credibilidad. En tales condiciones, y si el círculo queda fijado de manera bastante neta, por ejemplo, si se trata sólo de juristas profesionales, sus desacuerdos no excluyen cierta intersubjetividad -lo razonable- de aquello que todos los del círculo puedan reconocer como más o menos plausible. Una intersubjetividad de este tipo (débil) es la que por lo habitual caracteriza los argumentos que se utilizan en las discusiones jurídicas, razón por la cual es justo afirmar que, en efecto, no son propiamente irracionales. Más bien se podría pensar que no hay por qué darse por satisfecho con un grado tan bajo de intersubjetividad, sino tratar de someter el razonamiento jurídico, en la mayor medida posible, al uso de argumentos estrictamente racionales, metódicos (en sentido propio). ${ }^{31}$

Ahora bien, la controversia judicial está sometida a reglas de procedimiento, establecidas en los códigos respectivos, de las cuales no puede negarse que son netamente intersubjetivas, las respetan el juez y las partes. Teniendo en cuenta este hecho, ¿podría decirse que, en realidad, el derecho no presenta un grado «débil» de intersubjetividad? Hay que distinguir dos aspectos: a) las reglas procedimentales del juicio, b) las justificaciones allí invocadas para la solución de fondo. El primero de estos aspectos no regula otra cosa que la conducción formal del proceso: quiénes pueden ser protagonistas del juicio, el orden de sus etapas, qué tipos de medios de prueba son admisibles y en qué momento serán presentadas, etc. El segundo aspecto, en cambio, consiste en saber si una conclusión de derecho sustantivo -por ejemplo, la sentencia- es verdadera, o justa. Es cierto que para

${ }^{31}$ En su célebre estudio (1953), como consecuencia del cual se produjeron las apologías contemporáneas de un pensamiento tópico para el derecho, el propio Viehweg subrayó que la jurisprudencia, justamente en razón de ese carácter de «tópica» que es propio de ella, no puede constituir un verdadero método, sino nada más que un «estilo» (cfr., en el libro de dicho autor, el núm. 6/1 in limine). Sobre la «tópica», vid.: Kriele (cap. 5), García, Otte, Struck (Topische...) Y para la crítica de tales procedimientos en general, cfr. por todos el \# 4 de Horak. 
lo primero suele caber un buen control intersubjetivo, cuando menos entre juristas; esto es, intersubjetividad para apreciar la legitimidad de la sentencia en lo que respecta al cumplimiento, para dictarla, de las normas procesales aplicables en ese juicio. Pero esta legitimidad, aunque ambas partes no la cuestionen, no excluye que en el mismo juicio haya, por el contrario, discrepancias sustanciales -falta de intersubjetividad- por lo que hace al otro aspecto, el de aceptar (o no) como correcto el contenido mismo de dicha sentencia. Aunque las partes reconozcan que ésta ha sido regularmente dictada, y también en consecuencia, que es válida como producto judicial y que su resultado es obligatorio para ambas partes, eso no obsta a que, probablemente, la parte perdidosa esté convencida de que la solución dada por el juez no es la más «razonable». En síntesis: intersubjetividad respecto al procedimiento, pero no-intersubjetividad, o intersubjetividad muy «débil», respecto al fondo. Cuando digo que el discurso jurídico no es intersubjetivo, o que sólo lo es «débilmente», me refiero en lo fundamental a normas del derecho sustantivo, material, las que reglamentan asuntos de fondo de la convivencia social; y ni siquiera a todas ellas en la misma medida, ni para todos los casos, sino sólo a aquellas (pero son muchas) que se prestan a más de una interpretación por parte de los propios juristas, en tales o cuales respectos. Por esa falta de univocidad es que, puede decirse, los sistemas de derecho positivo no conforman, cada uno de ellos, un orden racional para el ordenamiento de la vida en sociedad, sino que simplemente ponen unas soluciones razonables -controvertibles y controvertidas- en manos de sus operadores.

Sin embargo, hay que tener presente que unos grados caben hasta para (dentro de) lo racional. Por ejemplo, la probabilidad de las leyes conocidas por las ciencias naturales es, desde luego, más firme que la de ciertos «patrones» racionales que Polya señala como aplicables incluso para la prueba judicial. ${ }^{32}$ Lo que importa, en cada caso, es saber hasta qué punto un razonamiento dado tiene plausibilidad, y es para eso que el método proporciona, mediante sus reglas de aplicación, un medio racional de control. Quiere decir que una conclusión puede presentarse, por la aplicación de tales métodos, ya sea como más o como menos

${ }^{32}$ Polya ofrece numerosos ejemplos del razonamiento plausible en matemáticas y hasta presenta unos «patrones de inferencia plausible» (caps. XII y XIII) que son de aplicación en campos como el del derecho; la parte en que Polya se refiere más específicamente a éste es en la sección 13 (titulada: Sobre la prueba judicial) del cap. XIII, págs. 316 y sigs. 
justificada racionalmente. Pero, repitámoslo, el grado -sea mayor o menor- de la plausibilidad de dicha conclusión es, en función del método (propiamente dicho) que sirve para controlarla, unívocamente comparable dentro del círculo. En cambio, la posibilidad de ese tipo de control falta respecto a todo aquello que no sea más que «razonable», como salta a la vista, por ejemplo, en las discusiones jurídicas.

Lo razonable aspira a la intersubjetividad propiamente dicha, pero no alcanza sino una intersubjetividad débil. Lo racional se esfuerza en alcanzar una intersubjetividad propiamente dicha (fuerte), iy la logra!

En resumen:

-distinguimos entre intersubjetividad propiamente dicha, fuerte, e intersubjetividad débil;

-a esas dos clases de intersubjetividad corresponden, respectivamente, lo racional y lo razonable;

-lo racional permite la elaboración de métodos propiamente dichos, que lo son en sentido estricto, mientras que lo razonable sólo puede dar lugar, en todo caso, a unos métodos en sentido amplio;

-a su vez, estas dos formas de métodos caracterizan, respectivamente, a dos tipos de ciencias, esto es, las que son tales en sentido estricto y las que no lo son sino en sentido amplio (o amplísimo).

\section{Excurso: las ciencias del derecho}

Del último punto en especial, la cuestión del tipo de ciencia que es (o pueda llegar a ser) el discurso del derecho, me ocupo en el sitio indicado en la nota 41, infra. Ahí llego a la conclusión de que, si el discurso jurídico corriente es «ciencia», no lo es sino en sentido amplio, o amplísimo. [Véase también supra, en el apartado V, el párrafo «Método y ciencia». Y cfr. infra, el Anexo final.] Esa idea central, que el pensamiento de los juristas no constituye una ciencia en sentido propio, ha sido subrayada más de una vez desde mucho tiempo atrás, por distintos autores (Kirchmann, etc.) y desde variados puntos de vista.

Por ejemplo, un autor como Cowan considera que: «La situación de la actual ciencia del derecho es comparable a la de la medicina de hace cien años, vale decir, que es una mezcolanza de ciencia, filosofía y técnica. (...) En opinión del autor, la «ciencia jurídica» debería llegar a ser parte de una ampliada ciencia social, dado que ésta se asienta más firmemente en una base experimental. (...) En cierto sentido, el derecho se relaciona con las ciencias sociales como la medicina con la ciencia 
biológica. De acuerdo con esta concepción, ni el derecho ni la medicina son ciencias en sentido propio. Más bien encarnan, ambos, conocimiento científico aplicado; son centros... [aquí siguen las palabras de este autor transcritas supra, a la altura de la nota 3]. (... ) En la última centuria, sin embargo, la medicina ha roto completamente con esta tradición y en forma creciente recogió resultados de las ciencias experimentales. La expresión 'medicina científica' ha llegado a ser un contrasentido lingüístico, pues hoy 'medicina no científica' significa magia o superstición. En cambio, ¿qué pasa con el derecho? ¿Por qué unos conceptos como 'ciencia del derecho' o 'derecho científico' no se contemplan como contradictorios en sí mismos?» (págs. 161-162 -loc. cit. supra, nota 3-). Y dice Aurel David: «El jurista cumple, pues, igual tarea que el técnico (médico, arquitecto), pero lo hace de otra manera. La diferencia no proviene de la cosa, sino del método: el derecho obtiene sus reglas de conducta mediante un procedimiento que he propuesto llamar 'oscuro', en tanto que las conclusiones de las ciencias naturales son lógicas y 'claras'» (en Studien und Materialien zur Rechtssoziologie, pág. 154 -loc. cit. supra, nota 3-). Cfr. también supra, a la altura de la nota 3, las palabras de Radbruch.

Mas tampoco faltan quienes, por el contrario, entienden que el discurso de los juristas no tiene por qué inspirarse en el modelo de ciencias más exactas (Perelman). Y hasta se puede argumentar que también la teoría de éstas contiene, en realidad, indeterminaciones análogas a las del pensamiento jurídico (Poirier).

Por otro lado, habría que tener asimismo en cuenta que no estamos ante una (sola) ciencia del derecho, sino que de éste «se ocupan hoy una serie de ciencias diferentes: la Filosofía del Derecho, la Teoría del Derecho, la Sociología del Derecho, la Historia del Derecho y la Jurisprudencia ('Dogmática jurídica'), por citar sólo las más importantes. Todas ellas contemplan a su vez el derecho bajo un aspecto diferente; por tanto, de modo diferente. Esto no sería posible si el derecho no fuera realmente un fenómeno complejo, que se manifiesta en distintos planos del ser, en conexiones concretas distintas cada vez» (Larenz, pág. 177 -vid. todo el apartado que comienza en esa página-). Cabe distinguir, por ejemplo, entre los siguientes «saberes jurídicos», en función de sus respectivos, diferenciales, ángulos y formas de su aproximación científica (Atienza, Introducción..., cap. 5): Historia del Derecho, Derecho comparado, Teoría general del Derecho, Antropología jurídica, Psicología jurídica, Análisis económico del Derecho, Sociología del Derecho, Lógica jurídica, Informática jurídica, Filosofía del Derecho. Cfr. también Dieter Grimm(comp.), Rechtswissenschaft und Nachbarwissenschaften (Ciencia del derecho y ciencias vecinas), C.-H. Beck (Schwarze Reihe, núms. 142 y 143 -2 vols.-), Munich, 1976, donde se estudian las relaciones del derecho con las siguientes disciplinas: sociología, administración, economía, psicología, criminología, política, historia, lógica, lingüística, informática, irenología, finanzas, didáctica. Esa circunstancia, que hay diferentes ciencias del derecho, debiera ser tomada en consideración, tanto si se piensa que todas ellas 
se refieren al fin de cuentas a un solo y mismo (aunque complejo) objeto-«derecho» como también si, en cambio, no hubiere tal objeto unitario, sino que cosas bastante heterogéneas son indistintamente subsumidas -y en común ontologizadas- bajo dicho nombre propio (la versión teorética más popular de esta ontologización es la llamada teoría «tridimensional» del derecho, de Miguel Reale).

\section{LO RACIONAL Y LO RAZONABLE}

\section{b) El papel del «buen sentido»}

Los partidarios de lo razonable tienen razón, sin embargo, en un punto. No sólo es cierto que el pensamiento jurídico es distinto, básicamente, de los razonamientos lógico-constrictivos, sino también que la racionalidad científica no está, a decir verdad, en condiciones de dar cuenta por entero del contenido de una decisión destinada a resolver cuestiones de derecho (supra, I in limine).

En efecto, la solución jurídica puede ser también resultado de unos factores que no pertenecen al plano propiamente de la razón. E incluso si hacemos abstracción de esos factores, es decir, si suponemos que un jurista sea capaz realmente de permitir que a su pensamiento jurídico lo guíen nada más que consideraciones de orden racional, aun así resulta que en numerosos casos se encontraría ante alternativas que él no puede resolver con sólo recurrir a la racionalidad. Es posible que también ésta deje sin cerrar del todo un espacio que quedará librado a precisiones complementarias u opciones, que no se pueden decidir y fundamentar por medio de métodos. Se plantea el problema, pues, de ver cómo es posible justificar las soluciones a que se llegue respecto a esos puntos, cuestión que se presenta tanto en el derecho como fuera de él.

Cabe señalar, ante todo, que tales aspectos tienen su sitio, si nos atenemos a un pensamiento metódico, dentro del marco que les fije el discurso racional mismo. Para dicho tipo de pensamiento, esos aspectos no pueden ser sino complementarios en relación con (y subordinados a) aquello que sí pueda ser determinado racionalmente. Ellos se limitarán entonces a llenar unas «lagunas» en el interior del marco trazado por el método, pero no deberían jamás desbordar los límites de este marco, atentar contra lo que haya podido determinarse (legítimamente) por vías racionales.

Conviene tener presente aquí la distinción y las relaciones que Vaz Ferreira (págs. 201 y sigs.) señalara entre razonamiento 
y lo que él denomina «instinto empírico» o «buen sentido hiperlógico». ${ }^{33}$ Tal «instinto» viene simplemente en ayuda del razonamiento; no se sustituye a él, sino que está destinado a completarlo, en aquellos casos donde el razonamiento es impotente para llegar por sí solo a las soluciones finales. Esto se aplica a «cuestiones de grado». Ese «buen sentido» se desprende de la experiencia; es algo así como una síntesis, una concentración de experiencias, que sirve para señalarnos en forma aproximada, hacernos «sentir» más o menos, cuál es el grado más adecuado como solución. ${ }^{34}$

\section{Límites del razonamiento: las cuestiones de grados}

Dice Vaz Ferreira: «... la cuestión de grados no se puede resolver de un modo geométrico. Lo único formulable es esto: 'En pro, hay tales razones; en contra, tales otras; hay que tenerlas en cuenta, a unas y a otras; pensar y proceder sensatamente según los casos'» (pág. 175). «Ahora bien: sería malo no razonar (o razonar parcialmente; esto es, ver sólo uno de los dos razonamientos; ya hemos enseñado la conveniencia que hay en hacer los dos). El razonamiento es bueno. Pero por sí solo no basta, en esta cuestión de casos y de grados. (... ) Se ve claramente la cuestión de grado: «hasta cierto punto», «no demasiado»; pero ¿dónde está ese cierto punto?; ¿cuánto es ése demasiado? ¿Cuáles son los límites precisos? Aquí, ya el razonamiento es impotente; lo que nos da la solución, sea en general, sea para cada caso, es la experiencia, cuando es posible; pero, cuando no es posible, es el instinto empírico, el instinto experimental que todos tenemos en mayor o menor grado, al que conviene no despreciar, y que completa el [al] raciocinio» (pág. 249). En tales casos, «lo más que podemos hacer en cuanto a raciocinio, es lo que ya hemos hecho, esto es: hacer los dos raciocinios, limitar el uno por el otro, y llegar a la conclusión de que debe haber algún punto, algún grado que sea el más conveniente o el más adecuado. Pero, ¿cómo puede resolverse cuál es ese grado? Únicamente por la experiencia. (... ) Pero como en la vida práctica la experiencia en muchos casos no es posible, o no está a nuestro alcance, o no es cómodo realizarla, o no se ha realizado, sencillamente -faltando la experiencia, nos encontraríamos completamente desarmados en estos casos

\footnotetext{
${ }^{33}$ Mas el propio Vaz Ferreira señaló que estas denominaciones no le parecen muy felices, que las usa porque no ha podido encontrar otras que sean mejores, «Siento que no es bueno este término: el que habría deseado encontrar querría decir el buen sentido en cuanto no es contrario al raciocinio o a la buena lógica...» (pág. 248, nota 1).

${ }^{34}$ Cfr. esp., en el libro de Vaz Ferreira, los caps. titulados «Pensar por sistemas, y pensar por ideas para tener en cuenta» (págs. 154 y sigs.) y «Valor y uso del razonamiento» (págs. 243 y sigs.); de allí fueron tomados los pasajes que se transcriben a continuación.
} 
grados, si no tuviéramos lo que se puede llamar el instinto empírico, esto es, una especie de instinto que sale de la experiencia general, que es como un resumen y concentración de la experiencia, y que nos indica más o menos, que nos hace sentir aproximadamente cuál debe ser aquel grado más justo» (pág. 247).

Estamos, en tales casos, ante lo que Vaz Ferreira llama «el 'buen sentido hiperlógico', esto es, esa especie de instinto lógico que, en las cuestiones de grados sobre todo (y muchísimas son cuestiones de grados, en la práctica), venía a intervenir después del raciocinio, o simultáneamente con él, para equilibrar los razonamientos opuestos, para mantener constantemente el juego de las múltiples ideas e impedir que una de ellas predominara indebidamente sobre las demás y nos llevara a la falsa sistematización» (pág. 171). Pero no se trata, ahí, «del buen sentido vulgar, o, mejor dicho, del buen sentido entendido vulgarmente, sino de otro buen sentido más elevado: del que yo llamaría buen sentido, no infralógico, sino hiper-lógico. El sentido común malo, ese que con tanta razón ha sido objeto de estigma de la filosofía y de la ciencia, el que ha negado todas las verdades y todos los descubrimientos y todos los ideales del espíritu humano, es el sentido común inconciliable con la lógica: el que no admite el buen razonamiento. Pero hay otro buen sentido que viene después del razonamiento, o, mejor, junto con él. Cuando hemos visto y pesado por el raciocinio las razones en pro y las razones en contra que hay en casi todos los casos; cuando hemos hecho toda la lógica (la buena lógica) posible, cuando las cuestiones se vuelven de grados, llega un momento en que una especie de instinto -lo que yo llamo el buen sentido hiperlógico- es el que nos resuelve las cuestiones en los casos concretos. Y sería bueno que la lógica no privara a los hombres de esta forma superior de buen sentido» (págs. 178-179). «Nótese bien que este instinto empírico no viene en lugar del razonamiento, sino además del razonamiento. (...) El instinto empírico gana con que el razonamiento le prepare las cuestiones: el razonamiento es completado por el buen sentido hiperlógico, controlador del raciocinio» (págs. 247-248).

«Los partidarios excesivos del razonamiento, los que creen que todo puede y debe formularse por el razonamiento, se equivocan, y se equivocan también, no hay que decirlo, los que pretenden prescindir del razonamiento con el instinto empírico. De esto depende, precisamente, que los espíritus falsos, como se ha observado, sean a menudo terribles razonadores: les falta ese control del sentido común hiperlógico. Muchas veces, son espíritus falsos, no porque razonen, sino porque no hacen más que razonar; no porque tengan una cosa, sino porque les falta otra» (págs. 251-252).

$\mathrm{Y}$ todo esto, que Vaz Ferreira señala respecto al uso del razonamiento en general, es aplicable también, desde luego, al caso (más específico) de la racionalidad. 
Claro que la manera como Vaz Ferreira caracteriza a dicho «instinto» es un tanto vaga. ${ }^{35}$ De ahí que, como él mismo lo subrayó, se trate de un dominio reservado justamente a un pensamiento no racional, a-racional, (no digo: $i$-racional), ${ }^{36}$ extra-racional, no metódico. Sin embargo, también semejante «Instinto», puede a menudo llegar a unos resultados que sean compartidos en general, vale decir, que son más o menos intersubjetivos (aunque no provengan de un razonamiento); en tal caso él es, de todos modos, la forma más consecuente de avanzar en el camino ya "preparado» por el marco racional que así es complementado. $\mathrm{Y}$ para aquellos casos donde, en cambio, el «instinto» de unos no coincidiera con el de otros, caben dos soluciones: o aceptar el veredicto de la mayoría (del círculo de conocedores), o remitirse al «buen sentido» de un órgano al que se reconoce como competente para decidir (por ejemplo, los tribunales de justicia).

Pero, aunque tanto lo razonable como el instinto empírico significan unos medios no racionales, ambos no son la misma cosa. El instinto empírico, en cuanto «instinto», interviene de un modo que es puramente intuitivo, constituye una forma inmediata de conocimiento; mientras que lo razonable, de cualquier manera, se basa en un razonamiento. Cada uno de ellos se puede

${ }^{35}$ No obstante, prefiero acudir a lo que Vaz Ferreira explicaba ya en 1909, pues las observaciones del filósofo uruguayo conservan todavía, a pesar de (e incluso por) la modestia con que están expuestas, toda su validez. Ellas acarrean ciertamente mucha menos confusión que ciertas ideas actuales de los partidarios de la «tópica», la «hermenéutica», la «argumentación», etc.

${ }^{36}$ Pareciera que la palabra «irracional» evoca unos fenómenos de conciencia que no son simplemente distintos del pensamiento racional, sino hasta anti-racionales. Ahora bien, no hay por qué entender que el «buen sentido» o lo razonable impliquen por fuerza tal cosa, lo antirracional; salvo, desde luego, si ellos alcanzaran a contradecir (propiamente) unas comprobaciones racionales, pero no si, como dice Vaz Ferreira (supra, notas 33 y 34), más bien éstas resultan ser complementadas por aquéllos. [Análogamente, respecto al «elemento del deber hacer», tratándose del problema de la fundamentación de las normas jurídicas, Norbert Hoerster («Ética jurídica sin metafísica», trad. de Carlos de Santiago, en: Ernesto Garzón Valdés, Comp., Derecho y Filosofía, Fontamara 50, México, 1988, págs. 111-134) dice que «puede inducir a error en grado sumo el estigmatizar a este elemento... Es tan poco irracional (antirracional) como, por ejemplo, el sentimiento de amor por una persona es, en tanto tal, irracional. Más correcto sería designarlo como arracional, es decir, no racional, extra racional» (págs. 119-120).] Por eso he preferido identificar esas otras formas, arriba, simplemente como «no racionales». Quiere decir que sólo quedan caracterizadas, ahí, por el rasgo negativo de no corresponder al plano II -sin ser tampoco del I ni del IV- y que no tienen por qué contradecir los resultados obtenidos en aquél. [Cfr. también Atienza (Para una razonable...), pág. 193 in limine.] 
utilizar con independencia del otro, y con o sin referencia a lo racional, mas también pueden complementarse entre sí.

\section{CONCLUSIÓN}

He tratado de precisar, a lo largo de este estudio, una alternativa que objetivamente se le presenta al jurista: la opción entre lo razonable y lo racional. Deseo subrayar ahora mi propia opción, que sólo insinué en los desarrollos presentados. Pienso que deberíamos esforzarnos por incrementar en la mayor medida posible el control metódico de los conocimientos también en las «ciencias del espíritu». Y para los tipos de casos en donde no sea posible alcanzar una intersubjetividad racional de su tratamiento, pero nada más que en la medida en que esto resulte verdaderamente imposible, allí el método debería ser completado mediante lo razonable o por vías hiperlógicas -ya que entonces no queda otra solución disponible, salvo el entregarse a la irracionalidad pura y simple.

Para que se llegue a proceder así, fundamental es, sobre todo, que el jurista quiera realmente efectuar ese esfuerzo de restringir al máximo la necesidad de recurrir a lo que es sólo razonable. Entonces la invocación de lo razonable no podría continuar siendo proclamada como ideal del pensamiento jurídico, al tenor de escritos como los de Viehweg, Perelman, Gadamer, Kriele, etc. Tal medio, por el contrario, ya no sería aceptable más que como último recurso, mal menor, solución de emergencia, sólo aplicable a una minoría de casos. Si la teoría jurídica llegara a aceptar que ha de orientarse hacia la elaboración o adaptación de métodos propiamente dichos, el derecho estaría en condiciones de alcanzar, también él, un grado mucho más alto de intersubjetividad.

Ahora bien, ¿por qué los juristas no consiguen ponerse de acuerdo sobre qué sea lo «racional», o lo «razonable»? Si examinamos tales discusiones fríamente, sin prejuicios, podemos darnos cuenta de que, al fin y al cabo, es el aspecto emocional de esos términos lo que preside su uso, como lo advertimos desde el principio (supra, I, in limine): aquellas son palabras de sabor esencialmente «persuasivo». ${ }^{37}$ De ahí que unos, partidarios de los

${ }^{37}$ Sobre el amplísimo papel que la «persuasividad» desempeña en el razonamiento práctico, cfr. el clásico libro de Stevenson, passim. Por lo que en particular se refiere a nuestro tema, qué es racionalidad, el carácter persuasivo que tienen todas las definiciones de este término -vale decir, también la nuestra- 
procedimientos tradicionales en el derecho, que otorgan (;de hecho!) un alto grado de libertad al juez, prefieren darle un sentido muy amplio a la idea de racionalidad, o cuando menos vincular esos procedimientos a otro término prestigioso: lo razonable. Mientras que otros, como el autor de este artículo, sin tanta confianza en la «sabiduría» de los jueces, se sienten inclinados más bien a poner el acento en la diferencia entre lo racional y lo razonable, vale decir, a llamar la atención sobre el importante coeficiente de arbitrariedad, o por lo menos de incertidumbre, que caracteriza a esta última clase de razonamientos. Los alegatos en favor de uno $\mathrm{u}$ otro de dichos conceptos, o de una $\mathrm{u}$ otra definición para cualquiera de esos términos, al fin de cuentas no son otra cosa que el reflejo de tales o cuales preferencias en materia de política jurídica, ${ }^{38}$ una façon de parler acerca de ésta. Pedir que el derecho sea racional, en el sentido apuntado, es

e subraya especialmente en mi comentario sobre la voz Rationalité (pág. 340, sec. III); pero también aquí mismo (supra, I in limine) hice la advertencia desde el comienzo. Vid. además la nota siguiente. [Ya Jhering había advertido el uso persuasivo -aunque él no le llamara así que se hace de las etiquetas «razón» y «racional». Cfr. las palabras de dicho autor que encabezan el presente trabajo, las cuales pertenecen a un pasaje que continúa así: «... ¿cómo podríamos llegar a un acuerdo sobre lo que es racional, dadas las profundas diferencias de opiniones que separan a los pueblos y a las épocas? (Y también, agregamos nosotros -E. P. H.-, las que separan a distintos sectores de un mismo pueblo y en la misma época.) Lo nuestro es racional; lo de ellos, si contradice lo nuestro, no lo es. También ellos invocan la razón en apoyo de sus instituciones y opiniones, y cuando las nuestras están en contradicción con las suyas, les parecen tan irracionales como las de ellos a nosotros. Pero lo que ellos llaman razón, no es la razón verdadera. Como yo me siento seguro de tener la verdadera, no me costará mucho trabajo deducir de la razón todo el derecho, que, por supuesto, sólo puede ser el de nuestra época (o el que esté de acuerdo con nuestra ideología -E. P. H-). Cuando se me presenten instituciones o reglas con las cuales no puedo declararme conforme, invocaré sencillamente mi propio raciocinio. Y si mis oponentes llegaran a invocar un 'ser' que no es el nuestro, los rebatiré diciendo que ése no es el verdadero 'ser'. El verdadero «ser» es solamente aquello que concuerda con la razón» (loc. cit. supra, nota 1 in limine).]

${ }^{38} \mathrm{O}$ sea, que inclinarse por una u otra definición de «racionalidad» es, en definitiva, una opción valorativo-heurística, con vistas a propugnar, en el campo de la razón práctica, aquello que se incluye (ipersuasivamente!) en la definición; y también, por contrapartida, es una manera de criticar y desechar lo que se ponga el acento en excluir de dicha definición. [Ese carácter valorativo-heurístico de la definición que se escoja -por ejemplo, la que se propone en el presente estudio- lo expliqué con más amplitud en el apartado final, «IX. Conclusión: la valoración disimulada y una cuestión de decisiones», de Lo racional y lo razonable: loc. cit. supra, nota inicial (*)]. 
pronunciarse en favor de la mayor previsibilidad (seguridad) posible de las decisiones judiciales. ${ }^{39}$

Los partidarios de lo razonable como pauta superior del discurso jurídico, pretenden presentar tal camino como si él resultara simplemente de la naturaleza misma de las cuestiones de que se ocupa el derecho, y no como lo que esa pauta es: una opción política. Tal presentación disimula el verdadero carácter de las soluciones que ellos defienden. Bien mirado, los escritos de esos autores vienen a ser una «ideología» del status quo del pensamiento jurídico corriente, Por lo menos de su metodología. ${ }^{40}$ (Sin perjuicio de que, además, es probable que también se trate de una «ideología» de la función social, conservadora, que predomina en la aplicación del derecho: cfr. los testimonios que al respecto aportan Sbriccoli y Rüthers, por ejemplo.) Mas no tengo inconveniente en reconocer que asimismo la posición que se sostiene en el presente artículo, a favor de la racionalidad -mejor dicho, de una determinada concepción al respecto-, es el resultado de una opción, ni pretendo haber demostrado que sea la «mejor» opción y que no existan otras posibles. El punto de vista que aquí se defiende no oculta su propio carácter de decisión valorativo-opcional, de política jurídica, o sea, de basarse en algo que es contingente. De ahí que, como él nada disimula (ni siquiera sobre sus propios motivos: encarar la crítica, ¡no la legitimación!, del discurso jurídico habitual), eso tenga por fuerza que chocar con la manera en que muestran las cosas

39 «Sobre la base de la exigencia de predecibilidad se elaboran modelos acerca de cómo deben ser las decisiones de este tipo (racionalidad), modelos según los cuales una decisión impredecible es básicamente una decisión arbitraria, es decir, irracional. En este sentido, la propiedad 'predecible' es presentada como una condición necesaria de la propiedad 'racional'. (...) Parece claro que esta exigencia depende de otra, cual es la de que tales decisiones tienen que tener su fundamento en el derecho «vigente»en tanto éste constituye un sistema de normas generales. Ello porque el conocimiento de las normas aplicables vendría a habilitar un pronóstico sobre los actos de aplicación. De aquí la conocida tesis de Max Weber que asocia la racionalidad del derecho moderno con su carácter sistemático. (... ) [Sin embargo], la 'predecibilidad' es presentada como una condición necesaria pero no suficiente, esto es, pueden existir decisiones irracionales predecibles» (Ricardo Alberto Caracciolo, «Racionalidad objetiva y racionalidad subjetiva», en DOXA 4 (1987) -Cuadernos de Filosofía del Derecho, págs. 145-151, Universidad de Alicante, 1987; la cita es de pág. 145). Todo lo cual no quita que: «Se pueden formular varias objeciones serias a la idea de que semejante conocimiento (el racional, sistemático) permite formular predicciones» (ibíd.), y en todo caso para el derecho (cfr. Frank).

${ }^{40}$ Cfr. el artículo indicado al final de la nota 30, supra, esp. sus apartados I y VI. 
los apologetas de la esencia razonable del pensamiento tradicional en el derecho. Las delimitaciones conceptuales efectuadas, buscan simplemente subrayar algunas de las decisiones previas que son necesarias para alcanzar un grado MAYOR de racionalidad en el pensamiento jurídico... jsi se quisiera alcanzarlo! He ahí el sentido de nuestra disputa de palabras en torno a lo que es «racionalidad» y «método»: hacer ver que la actual racionalidad y el actual método del discurso jurídico podrían y deberían ser sustituidos por OTRA racionalidad, otros métodos, supuesto que hubiera la VOLUNTAD política -también por parte de los juristas- de hacerlo así.

Resumo mis conclusiones en cuatro puntos:

-De la circunstancia de que el pensamiento lógico-formal revista sólo importancia secundaria para decidir respecto a la generalidad de las cuestiones jurídicas, de eso no se sigue que la única alternativa verdadera, en este campo, esté confinada a una opción entre lo irracional y lo razonable; no es así, porque además se halla abierta la posibilidad de acudir a lo racional.

-Si no se está de acuerdo con que el derecho dependa tan a menudo del sentimiento del «buen juez», o simplemente de la costumbre o de presiones sociales ejercidas sobre la persona de ese juez, no hay otra salida que la de esforzarse por incrementar lo más que se pueda, también en el discurso jurídico, el papel de lo racional en sustitución de lo razonable -reducir esto último al mínimo, promocionar aquello al máximo-. Es ése el único camino, el de lo racional, el del método, para llegar a tener una ciencia (en sentido propio) del derecho.

-La alternativa entre lo racional y lo razonable corresponde, al fin de cuentas, a la que existe entre someter el pensamiento jurídico a unas reglas generales (ipero unívocas!) preestablecidas y un derecho mucho más elástico. En este último caso, que es la vía tradicional, las cuestiones metodológicas son, en realidad, de importancia secundaria o hasta ficticias; más decisiva resulta entonces la «equidad» del juez, quien así disfruta de un buen grado de libertad de interpretación, sobre todo por la cantidad de 
conceptos indeterminados que integran el discurso jurídico (tanto en los propios textos positivos como en la doctrina y la jurisprudencia).

-Y dicha alternativa no es, en el fondo, otra cosa que una cuestión de política jurídica, o sea, de preferencias ideológicas respecto al papel que en una sociedad están llamados a desempeñar los preceptos del derecho y sus operadores.

Los juristas realizan opciones, pues, en cuanto a las vías intelectuales que adoptan para desarrollar su discurso. Si desearan poner en práctica un tipo de pensamiento que sea propiamente racional, sería necesario sobre todo que estén dispuestos a someter sus razonamientos a unos verdaderos métodos (en sentido estricto). Para quienes QUIERAN abordar tal camino, he aquí lo que, en consecuencia, deberían hallar y aplicar:

un conjunto de procedimientos intelectuales, y eventualmente materiales, ordenados de acuerdo con un plan racional -sistema de reglas- preestablecido, que en un campo de conocimientos dado se aplican como medio para alcanzar cierto fin, de conocimiento puro o de realizaciones prácticas; procedimientos que en su ejercicio y resultados (praxis) logran acreditar intersubjetivamente su efectividad en relación con dicho fin, para los ojos -lógica constrictiva o plausibilidad- de un determinado círculo de conocedores (en nuestro caso, el círculo de los profesionales del derecho) que se guían por el saber teorético-sistemático disponible [«ciencia normal»: Kuhn] en ese campo (saber del cual tales procedimientos pueden servir, a su vez, como «test» para someterlo a contrastación: falsabilidad).

A la luz de esta idea general de lo que es MÉTODO CIENTÍFICO, habría que determinar los modelos particulares aptos para las funciones del derecho: los tipos, especies, de métodos adecuados al trabajo del jurista, a sus funciones como tal. La idea general, que es el asunto del presente estudio, no puede tener más que un valor HEURÍSTICO con vistas a delinear esas especies, que son las que cabría aplicar en concreto. Es mediante la realización de unos esfuerzos intelectuales que vayan precisamente en aquella dirección general, o sea, si se adopta como pauta programática dicha idea básica (¡no otra!) como podríamos 
llegar a saber si racionalidad y método científicos son o no son posibles para el derecho. ${ }^{41}$ Con otras palabras: averiguar, puesto que el discurso del derecho pretende tener un carácter «científico», qué tipo de ciencia él es o pueda llegar a ser. ${ }^{42}$

${ }^{41}$ Pero ya en mi Tesis de París (cfr. sus tres últimas líneas, pág. 425 [pág. 140 en la trad. cit. supra: nota inicial $(*)$ ] subrayé, como en el presente estudio, que la posibilidad de sujetarse a procedimientos firmemente racionales es algo que está subordinado a una elección, opción, de quienes operan el discurso jurídico, sobre todo sus locutores profesionales. Depende, pues, del hecho de que los juristas QUIERAN, en realidad, someterse intelectualmente a una verdadera (en el sentido definido arriba) racionalidad: a las EXIGENCIAS científicas que constituye el resolver las cuestiones mediante tal tipo de discurso, no lo simplemente razonable. Claro que si se tiene en cuenta lo que el derecho ha sido siempre (cfr., por ejemplo, Horak, Sbriccoli y Rüthers), no hay lugar para ser optimista acerca de esa posibilidad. No obstante, el destacar la dirección en la que habría que marchar para acceder a un pensamiento propiamente metódico en el derecho puede contribuir, en todo caso, a tener un conocimiento mejor, esto es, menos ingenuo, más CRÍTICO, respecto al razonamiento habitual de los juristas. Y he ahí, tal vez, lo más interesante que pueda ofrecernos la filosofía, y también la ciencia social: permitirnos tomar conciencia de qué es lo que podría y debería ser distinto, aun allí donde otros seguirán logrando que eso no cambie.

${ }^{42}$ De tal cuestión específicamente, cuál es ese «tipo», me ocupo en otro sitio: Ciencia jurídica: ¿QUÉ «ciencia»? Lo que se explica en dicho estudio, puede considerarse como una continuación y complemento de lo expuesto aquí. Cfr. también supra, VIII in fine (Excurso). 


\section{POSTSCRIPTUM (1989)}

Hasta la ciencia es, para muchos, una nueva fuente de ilusión, una nueva huida del cambio y del azar, un nuevo camino hacia lo absoluto. Pues, desafortunadamente, para muchas personas la ciencia es una carta de certeza... Sea lo que fuere aquello que se pueda desear que el mundo del derecho sea, éste es y casi con seguridad será [siempre] incierto.

J. Frank

Precisamente porque el elemento personal no puede ser enteramente excluido, mientras que, a la vez, la decisión tiene que asumir lo más cercanamente posible una forma impersonal, objetiva, racional, está la tentación de dejar de lado la lógica vívida que realmente condujo a la conclusión, y sustituirla por formas de hablar que son rigurosas en apariencia y brindan una ilusión de certeza.

Dewey

Es preciso haber perdido toda fe en la teoría, para poder servirse de ella sin peligros.

Jhering

La historia de la ciencia constituye, toda ella, una sola y grande confirmación del hecho de que en todas partes nos resulta difícil adoptar, por ejemplo, una aproximación científica nueva. El pensamiento nos encarrila siempre de nuevo por el derrotero acostumbrado, incluso si éste se volvió inadecuado y aunque lo nuevo, más adecuado, de por sí no ofrezca ninguna dificultad especial.

Schumpeter $^{\mathrm{a}}$

Podría decirse que el estudio presentado, en vez de examinar principalmente lo que el derecho es, más bien se refiere a una cosa que éste no es. Sin embargo, eso -racionalidad, método, ciencia- que él NO es, o que sólo en débil medida es, no significa una ajenidad cualquiera, algo cuya falta tenga poca relación con el papel que el discurso jurídico pretende cumplir. Si, como

${ }^{a}$ Frank (Law...), págs. 307 y 308. Dewey, pág. 24. Jhering, pág. 67-68 (la misma idea se retorna también en las págs. 71-72 y 115). Josef Schumpeter, cit. en Albert, Tratat über rationale Praxis, pág. 59. 
reza la célebre sentencia de Spinoza, Omnis determinatio est negatio (toda determinación es una negación), también lo recíproco es cierto: al negar algo respecto al objeto (o tipo de objetos) A, eso implica predicar una determinación acerca de ese mismo objeto. Diciendo que A no es B, de alguna manera delimitamos lo que A sí es o pueda ser, estamos afirmando algo del propio $\mathrm{A}$. Cuando aprendemos que $\mathrm{A}$ es otra cosa que $\mathrm{B}$, conocemos mejor a $\mathrm{A}$; entonces sabemos más de A que si esa diferencia no la tenemos clara. (Formulado en términos más ampulosos: el propio «ser»-determinatio, positividad, afirmación- de A consiste, entre otras cosas, en ese su «no-ser»-negatio- B). ${ }^{\mathrm{b}}$ Claro que las negaciones pueden ser tan triviales que, en la práctica, no valga la pena detenerse a formularlas de modo explícito. Pero en muchos casos no es así. No siempre se distingue a primera vista, y a menudo ni siquiera lo advierten exámenes en profundidad, cosas (importantes) que A no es.

En cuanto al derecho, no está nada claro, si nos atenemos a la conciencia común de sus operadores y a la doctrina jurídica de mayor recibo, cuál es $s u$ «racionalidad», $s u$ «método», su verdadero estatus de «ciencia». Y eso podemos plantearlo también así: preguntar en qué cosa no consiste su tipo de razonamiento, qué cosa no son su método y su ciencia, por contraste con lo que caracteriza a otras disciplinas científicas. Como estos tres términos -racionalidad, método, ciencia- son ambiguos, y también vagos, para contestar a dicha interrogación hay que comenzar por precisar lo que significa cada uno de ellos (de eso se ha ocupado el presente trabajo); luego podremos averiguar si, de acuerdo con ese o esos significados, corresponden $o$ no a la práctica del derecho. Tal pregunta tiene su importancia -ya que la respuesta no es obvia- para aquilatar lo que el discurso jurídico es en verdad. Si queremos alcanzar una conciencia realista sobre el derecho, vale decir, llegar a ver más allá de lo que nos dicen sus textos oficiales y su dogmática, importa advertir cuánto no es ni racional ni metódico en el orden de pensamientos que cultivan sus operadores, y sobre todo relacionándolo con el funcionamiento

${ }^{\mathrm{b}}$ «... sólo comprendemos por vía de contraste, a saber, cuando entendemos qué es la ausencia de lo comprendido porque el objeto aparece en el trasfondo del mundo que él mismo no es. El acto de reconocer o de identificar la cosa es simultáneo con el movimiento conceptual que alcanza lo que la cosa identificada no es: Omnis determinatio est negatio. Si decimos que algo es de cierta manera, sólo lo sabemos cuando sabemos de qué manera es otra cosa que no es precisamente de esa manera» (Leszek Kolakowski, La presencia del mito, trad. de Cristóbal Piechocki, Amorrortu, Buenos Aires, 1975, pág. 66). 
de ese discurso en el plano de su aplicación (o faltas de aplicación) práctica. Sin empezar por saber qué es racionalidad y método científicos, o sea, lo que el derecho NO es, difícilmente se logre percibir lo que él sí es.

La discusión, siempre renovada, acerca de lo que quieren decir unas palabras como «racionalidad», «razonable», «método» y «ciencia»-u otras: «razón», «verdad», «justicia», «libertad», «democracia», y hasta el propio término «derecho», etc.-, se justifica porque, lo queramos o no, ellas constituyen la llave lingüística por medio de la que nuestra atención es dirigida hacia ciertos círculos de cuestiones cuya solución tiene influencias decisivas sobre la vida cotidiana. Sólo que, para no engañarse en tales discusiones, habría que tener claro, y los que protagonizan esas discusiones no suelen tenerlo, que somos nosotros mismos quienes como locutores, al emplear dichos vocablos de acuerdo con unos u otros sentidos, decidimos utilizarlos así. Esta decisión, la de optar por tal o cual significado al usar la palabra discutida, es tributaria de los intereses de conocimiento y de acción del grupo de locutores que prefiere dicho sentido (y que deja de lado otros). Para la misma palabra, unos grupos eligen el sentido $\mathrm{X}$ y otros adoptan el sentido $\mathrm{Y}$, porque difieren los propósitos de aquéllos y éstos al emplearla. La raíz de sus discrepancias reside verdaderamente en eso, en el sentido práctico distinto que le dan al usarla, y no en el conocimiento o desconocimiento de un imaginario cielo de inconmovibles significados que serían inmanentes a cada término (cfr. Jhering, parte III: «En el cielo de los conceptos jurídicos»). De ahí que, no obstante este carácter opcional, y «persuasivo», que siempre tiene cualquier definición que se proporcione de dichos términos, la verdad es que tales discusiones, aunque analizadas desde el punto de vista lógico no sean mas que unas «cuestiones de palabras», resultan no ser inofensivas desde el punto de vista práctico. Pues lo que a través de ellas se debate, en el fondo, es qué debamos pensar -iy hacer!- respecto a cosas que nos afectan de modo fundamental. Al aceptar que la palabra en cuestión comprende algunas de esas «cosas», pero no otras, con ello testimoniamos que las primeras gozan de nuestra bendición, y más bien se la negamos a las segundas. ${ }^{\mathrm{c}}$ Tal opción contribuye a predisponernos, por lo menos en principio, a actuar en favor de aquéllas, y no (o mucho menos) en favor de éstas. Con terminología

${ }^{\mathrm{c}}$ Las palabras son galardones que cada persona trata de conferir a las cualidades de su predilección» (Stevenson, pág. 199). Cfr. supra, nota 9. 
de la semiótica: si bien cualquier significado de una palabra es tan convencional y arbitrario como cualquier otro, en el plano de la semántica; eso no quita que ellos tengan, al ser usados, distintos efectos reales, en el plano de la pragmática lingüística. Hay «cuestiones de palabras» que, aunque estériles desde el punto de vista lógico-semántico, están cargadas de consecuencias en cuanto al uso pragmático-social de ese discurso.

En una discusión como, por ejemplo, la presentada en mi estudio, el hacer ver que la palabra «método» tiene distintos sentidos permite tematizar que los métodos (sentido amplio) corrientes del derecho podrían ser reemplazados por otros métodos (sentido estricto), vale decir, que también una mejor «ciencia» del derecho es concebible. Al traer a colación, tomando como modelo lo que es propio de otras ciencias, la idea de una «racionalidad» en sentido estricto, ello sirve como elemento de comparación frente al pensamiento jurídico habitual, pone de relieve que habría la posibilidad de transformarlo en un discurso menos manipulable. Estas cuestiones de palabras -precisar a qué «racionalidad», qué «método», qué «ciencia» nos referimos- implican sentar unos criterios en función de los cuales se pasa a juzgar las materias a que dichas definiciones se aplicarán. Según cuál sea la definición elegida, será el juicio de apreciación, basado en ella, sobre los asuntos en examen: por ejemplo, acerca del derecho. Las definiciones que se acepten, funcionan como pautas heurístico-críticas para evaluar, transformar o elaborar las realidades que se miran a la luz de aquéllas. Tales cuestiones de palabras, lejos de agotar su influencia en el nivel semántico únicamente, son ni más ni menos que indicaciones para la praxis. (Indicaciones que, como cualesquiera otras, serán seguidas o no, según el conocimiento, la voluntad, los intereses y las limitaciones reales de sus destinatarios.) Porque la definición que se elija es una guía, y suele implicar una justificación, para tal o cual género específico de prácticas, por eso distintos grupos de opinión -diferencias ideológicas, de intereses, etc.- discuten con tanta pasión sobre cuál es la definición «verdadera» del término de que se trata. Así, mientras que las definiciones propuestas en el presente estudio constituyen unos instrumentos para la crítica del discurso jurídico común, otras definiciones (menos estrictas) de esos mismos vocablos obran, por el contrario, como escudos intelectuales que legitiman ideológicamente el status quo de dicho discurso y la formación tradicional de los juristas (cfr. supra a la altura de las notas 29 y 37-38, y aquí mismo, infra, lo relativo al «Tipo I»). 
Desde luego, tanto «racional» como «razonable» se pueden definir también de cualquier otra manera (supra, nota 9). Por ejemplo, Atienza distingue entre «'racional' (a secas)» y «estrictamente racional», haciendo que lo primero comprenda también lo «razonable»; y señala que esto último, a su vez, puede entenderse en sentido amplio o en sentido estricto (Para una razonable..., págs. 192 y sigs.). En fin, lo cierto es que la línea divisoria entre lo racional y lo razonable puede trazarse en unos u otros puntos, según lo que se quiera destacar, o disimular, y lo que se desee proponer.

Por mi parte, he querido poner principal énfasis en la cuestión de la INTERSUBJETIVIDAD (fuerte) que caracteriza al discurso de la ciencia normal en todas las disciplinas más avanzadas y metodológicamente exigentes. De ahí que haya propuesto una definición «estrecha» para el término racionalidad (cfr. supra, entre las notas 13 y 14), aunque en modo alguno se me oculta que ella no es ni más ni menos estipulativa que cualquier otra definición de dicho término. Toda definición de unos términos teoréticos se elige por determinado interés de conocimiento. En mi caso, juzgué importante comparar el pensamiento jurídico habitual con el de ciencias más exigentes; mi definición es heurística, para ese fin.

Desde tal punto de vista, no me parece bastante «estricta», en cambio, una definición como, por ejemplo, ésta: «Una decisión jurídica es estrictamente racional sí y sólo sí: 1) Respeta las reglas de la lógica deductiva... Por 'lógica deductiva' hay que entender aquí la lógica clásica de predicados de primer orden. (... ) 2) Respeta los principios de la racionalidad práctica... a saber, los principios de: consistencia, eficiencia, coherencia, generalización y sinceridad. 3) Se adopta sin eludir la utilización de alguna fuente del derecho de carácter vinculante. 4) No se adopta sobre la base de criterios éticos, políticos, etc., no previstos específicamente (aunque pudieran estarlo genéricamente) por el ordenamiento jurídico» (Atienza, loc. cit., págs. 193-194 -la cursiva es mía-). Pienso que esta noción de racionalidad, y otras análogas, justamente no debiera calificarse de «estricta», porque ella, a diferencia de la nuestra, NO permite trazar una verdadera línea divisoria entre el razonamiento científico normal (intersubjetividad fuerte) y todo aquello que es sólo razonable (intersubjetividad débil). La definición transcrita, si es aceptada, hace que lo racional resulte no menos azaroso que lo razonable, ya que las faltas de intersubjetividad se cuelan sin dificultad por esos ítemes. Por ejemplo: 3) con frecuencia es discutible, precisamente, qué fuente de derecho sea la «vinculante» para un caso dado, pues esto depende nada menos que de la variada interpretación de los textos del derecho (y también de la de unos hechos); 4) del mismo modo, qué criterios estén previstos «específicamente» por el ordenamiento jurídico, sobre todo si se trata de vincularlos a decisiones concretas, es cosa no menos discutible y discutida que lo anterior, cada parte entenderá que es «específico» el criterio que ella invoca y no aplicable el aducido por la contraparte. Aunque Atienza ofrece una definición distinta para lo que él llama «razonable en sentido estricto» (pág. 
193), la multiplicidad de interpretaciones que tolera también aquello otro que él denomina «estrictamente racional» hace que, en la práctica, así cualquiera de las dos calificaciones resulta igualmente aplicable -desde el punto de vista semántico, o sea, sin violar dichas definiciones- a la mayoría de las decisiones jurídicas habituales.

O bien, por ejemplo, que la «tópica» sea considerada como algo que es racional, razonable o ninguna de las dos cosas, también eso depende del valor que se le quiera reconocer a la intersubjetividad (fuerte) como modelo para el pensamiento jurídico. Acerca de esto, Viehweg fue más franco, y también mucho menos pedante, que otros teóricos de lo razonable (supra, nota 31). Es acertada una observación de Kriele al respecto (él la hace con referencia a la tópica, pero es válida para lo razonable en general, o sea, también para la posición que sostiene el propio Kriele en materia de metodología jurídica): «Por regla general, claro que allí estará ausente el consenso, pues un problema constitucional yun proceso constitucional [y también las cuestiones discutidas en otras ramas del derecho] surgen precisamente de la falta de consenso (de 'diferencias de opinión o dudas' sobre la interpretación de la Constitución -art. 93 GG-); y la falta de homogeneidad en el gremio de los juristas y en la sociedad en general, hace que la escala de las posibles diferencias de opinión se nos aparezca como casi infinitamente ancha. Esta vaguedad e inseguridad ha provocado dudas respecto a la tesis de la tópica...» (págs. 151-152). Dudas en cuanto a las que, de todos modos, importa considerar una precisión: «Si alguien invoca aquí el carácter lesivo de esta construcción para el principio de legalidad o la seguridad jurídica, la réplica podrá ser distinta según que la tópica [e igualmente la argumentación, la hermenéutica, etc.] se entienda como descripción o como propuesta normativa» (García, pág. 175). ¡Sólo que, casi siempre, los apologetas de lo razonable no hacen ver tal diferencia!

La definición que en la Teoría del Derecho se escoja respecto a los términos discutidos es, por tanto, algo así como la síntesis y el punto de partida para programas de política jurídica. Es cierto que aceptar una definición de racionalidad y de método como la retenida por nosotros, significa postular una política, en materia de métodos para el derecho, que bien se puede calificar de utópica. Lo es, en efecto, pues contraría los hábitos intelectuales más arraigados en el gremio de los juristas y, por añadidura, también va a contrapelo de las funciones retórico-ideológicas que está llamada a desempeñar buena parte del discurso jurídico. Pero este carácter de «utopía» que tiene el pretender que el derecho llegue a incorporar niveles de racionalidad como los alcanzados en otras ciencias, no es otra cosa, precisamente, que un rasgo característico de los programas políticos, y tanto más cuanto menos éstos se priven de sacar a la luz aspectos de 
los cuales los partidarios del status quo prefieren no hablar. La utopía es, desde Platón, una manera de presentar las cosas en donde, sobre todo, es cuestión de hacer más patentes los fallos del modelo real, por contraponerle ese modelo ideal. La utopía -negación- permite conocer mejor lo que es -determinación- la no-utopía, el status quo, y sea o no que éste pueda en la práctica ser finalmente cambiado en una dirección que deje a la realidad menos lejos de lo que por ahora resulta utópico. No otro es el sentido de la orientación «utópica» que respecto al derecho pueda tener el saber lo que son racionalidad y método científicos, cosas que el derecho no es, si estos términos se entienden según fueron definidos aquí (cfr. supra, nota 40 in fine).

Hemos hablado de ciencia en sentido estricto; y la distinguimos del tipo de «ciencia» que domina en el pensamiento jurídico, el cual en todo caso no es más que una ciencia en sentido amplio (o amplísimo). La ciencia en sentido estricto, según fue definida aquí (supra, VIII in fine), corresponde a lo que Kuhn llama «ciencia normal»: la conformada por los conocimientos y la práctica intersubjetivamente reconocidos como legítimos por la generalidad de los profesionales de una disciplina científica dada, en determinada etapa del desarrollo histórico de ésta. Desde luego, tales conocimientos y prácticas pueden llegar a cambiar; pero también suele suceder que, además del acervo de conocimientos que allí son los «normales» en un período, aun entonces haya ciertos puntos y teorías más discutibles dentro de esa rama, o sea, unos aspectos para los que falta o es menos fuerte la intersubjetividad que reina en el resto («normal») de dicha ciencia. Todo eso puede dar lugar, aunque no necesariamente, a lo que Kuhn denomina «ciencia extraordinaria»: cuando algunos científicos, para resolver ciertas cuestiones fundamentales a las que no está en condiciones de contestar satisfactoriamente la ciencia normal, llegan a subvertir criterios básicos de ésta, con el fin de solucionar esos problemas (puzzles). A diferencia de la ciencia normal, la extraordinaria no presenta -por lo menos mientras ésta no consiga (con el tiempo, acaso) imponerse a su vez como ciencia normal- una «racionalidad» en el sentido apuntado aquí (supra, a la altura de la nota 13), ya que la ciencia extraordinaria carece, por definición, de la intersubjetividad que caracteriza a la ciencia normal. [Sobre todo esto, cfr. Lakatos/ Musgrave.] 
Si para el derecho hubiera una ciencia en sentido estricto y que allí fuese la normal, eso no quitaría, por supuesto, que en algún momento pudiera ser subvertida por nuevos paradigmas de razonamiento jurídico, los cuales entonces significarían, respecto a aquélla, una ciencia extraordinaria. Mas no es ése el tema del estudio precedente, pues en él no se examina una ciencia jurídica en sentido estricto que funcione como ciencia normal. Si puede decirse que hay una ciencia jurídica normal, la tradicional, ésta se caracteriza precisamente por no ser ciencia en sentido propio (supra, VIII in fine), a diferencia de lo que son las ciencias normales en otras disciplinas. La cuestión que se discute en ese estudio es, pues, otra: suponiendo que el derecho tenga o pueda llegar a tener una ciencia «normal», ¿qué hace falta para que, además, ésta consiga ser racional y metódica, en sentido estricto?

Cuando tal pregunta es abordada, directa o indirectamente, en estudios que están al día con enfoques avanzados de la actual Teoría General del Derecho, o aquello con que en alemán se llama Investigación de Bases del pensamiento jurídico (Rechtsgurnlagen-forschung), el examen sobre la racionalidad del discurso de los juristas se lleva a cabo de acuerdo con tres grandes tipos principales de orientaciones teoréticas. Dos de ellos (Tipos I y II) son, en el fondo, optimistas en cuanto a la presencia de tal racionalidad o la posibilidad de llegar a alcanzarla; el otro (Tipo III) lo es mucho menos, o no lo es en absoluto.

Tipo I.- Éste constituye una tendencia netamente conservadora. La forman aquellos autores para quienes el pensamiento jurídico profesional está bien como está, consideran que él ya es lo bastante racional o razonable. Entienden que, en lo sustancial, nada hay que criticar ni que corregir en ese discurso, detalles aparte, por lo menos para el que se hace presente en las democracias capitalistas de Europa occidental. Por eso piensan que alcanza, para obtener la teoría científica acerca de él, con sacar a la luz y destacar los modelos de razonamiento que los juristas manejan de por sí en forma habitual, o sea, revelar su propia racionalidad o razonabilidad. Tal es, en general, la posición de los topicistas, los hermeneutistas, los apologetas de la argumentación jurídica razonable, etc.; cfr., por todos, los trabajos de Perelman. ${ }^{\mathrm{d}}$

\footnotetext{
${ }^{\mathrm{d}}$ Cfr. también supra, a la altura de las notas 29 y 30, e infra, el punto 2 del Apéndice. Y Perelman no oculta, por cierto, dicho carácter apologético, cfr., por ejemplo, el artículo donde subraya «Lo que el filósofo [y no sólo este] puede aprender por el estudio del derecho» (Ce que le philosophe...). Otro ejemplo: asimismo Gadamer consagra un apartado de su influyente obra a destacar «El carácter paradigmático [ejemplar] de la hermenéutica jurídica» (cap. 10.3). Por otro lado, estudios como el de
} 
Tipo II.- Estos otros estudios, en cambio, se orientan a lograr una mejora del discurso jurídico, o a lo menos en las vías para analizarlo. Proponen el empleo de técnicas del pensamiento que, según opinan esos autores, son más racionales que las que en la actualidad suelen emplear los juristas. Las direcciones que se señalan para hacer tal cosa son muy variadas, prácticamente tantas como las escuelas sobre formas del discurso científico en general. Muchos de dichos estudios, acaso los más «técnicos», ofrecen poco o ningún interés desde un punto de vista como el del propósito central que persigue nuestro estudio: señalar pistas para hallar criterios capaces de hacer verdaderamente metódico el discurso profesional del derecho, o sea, someterlo a unas pautas que en la mayor medida posible permitan que también en él lo razonable esté encauzado, limitado, mediante lo científico-racional. Nuestra respuesta fue que, si tal posibilidad existe, hay que buscarla por vías de la adaptación o la construcción -a diferencia de lo que en la actualidad domina en el pensamiento jurídico- de unos métodos en sentido estricto que sirvan para resolver cuestiones de derecho. No es hacia ahí, sin embargo, que conducen los caminos constituidos por las innovaciones teoréticas que manejan ciertas corrientes actuales, de quienes la navaja de Ocam se apiade, donde por «ciencia» pareciera entenderse más o menos lo mismo que desaforada inflación de tecnicismos o esquematomanía: lógica deóntica, semántica estructural, etcétera. ${ }^{\mathrm{e}}$ Pero también hay, es cierto, modernas tendencias de investigación

Toulmin o el de Poirier, aunque no sería justo calificarlos de propiamente apologéticos respecto del pensamiento jurídico, pueden ser usados en apoyo de las posiciones del Tipo I.

${ }^{\mathrm{e}}$ Estas aproximaciones se inscriben dentro de una gran corriente, que sobre todo ha cobrado mucho impulso en los últimos años, cuyos autores suelen entender que sus estudios responden a un campo específico de investigaciones denominado semiótica jurídica. Pero, en realidad, bajo tal rúbrica entran orientaciones metodológicas distintas y muy variados énfasis temáticos (al respecto se puede cfr. Jackson y también: Colloque International de Sémiotique Juridique, Roque Carrión-Wam ed., Revue de Recherche Juridique. Droit Prospectif, 1986-2, Presses Universitaries d'Aix-Marseille). De ahí que, junto a direcciones como las arriba mencionadas, donde todo el ingenio reside en la inusitada pedantería con que allí se pergeñan toda clase de formalismos, también haya otras que se dedican a abordar cuestiones más sustantivas a partir de unos análisis de lenguaje: los conflictos de interpretaciones en el derecho, funciones sociales del lenguaje jurídico, incidencia de ideologías en el discurso de los juristas, diferencias entre las normas del derecho, etc. (cfr. por ejemplo, la Parte Tres del libro de Jackson sobre Semiotic and Legal Theory y algunos de los estudios (Roberta Kevelson, Peter Goodrich, Domenico Carzo) del mencionado Colloque; vid. además el opúsculo de Bernard S. Jackson, Semiotics and Critical Legal Studies, Working Paper di Sociologia (núm. 4), Universidad degli Studi di Messina, Facoltà di Scienze Politiche, 1986. Téngase en cuenta que: «Hay, 
que no comulgan con esos fuegos fatuos; no se dedican a multiplicar terminologías pedantes para decir trivialidades o para solazarse en distinciones tan minuciosas como estériles, sino que tratan cuestiones de verdadera importancia para la práctica del razonamiento vivo dirigido a resolver problemas sustanciales del derecho. Así, en años recientes se han dado a conocer estudios donde, con base en teorías de la argumentación, ${ }^{\mathrm{f}}$ pero orientándose hacia niveles teoréticos que conducen

por cierto, algunas aproximaciones (approaches) en la semiótica que sostienen que todas las relaciones son de texto, y que el contexto socioeconómico mismo tiene que ser textualizado, analizado semióticamente, y sus relaciones con otros textos ser concebidas en términos de intertextualidad más bien que con referencia a modelos científicos sociales (particularmente los causales) ${ }^{50}$. (50. La escuela de Greimas [semántica estructural] es a menudo vista de esa manera... La cuestión es compleja, e implica el asunto de la referencialidad...) Pero existen también otras aproximaciones en la semiótica, que se ven a sí mismas como estrechamente integradas con la sociología» (Jackson, Semiotics and Critical Legal Studies, pág. 12). En cuanto a este último punto de vista, cfr. esp., entre los materiales del Colloque, la contribución de Carzo (págs. 357-363): «Considérations sur la sémiotique juridique: le point de vue sociologique»; y compárese, por ejemplo, con el aparatoso despliegue de jeringonza en que, para decir trivialidades o inflar unas analogías meramente pedantes, se solaza el autor que allí representa a la semiótica estructural aplicada al derecho (Eric Landowski, «Pour une approche sémiotique et narrative du droit», en ibíd., págs. 39-69).

${ }^{\mathrm{f}}$ «'Argumentar' quiere decir: indicar las razones que permiten que una afirmación aparezca justificada, acertada o, al menos, discutible. Las razones para alcanzar esta meta tienen que ser propuestas de tal modo que convenzan al presunto participante en la discusión, que sean capaces de que supere, por ejemplo, las razones opuestas por él alegadas. Quien esboza una Teoría de la Argumentación piensa sobre todo en la discusión de las cuestiones jurídicas ante el tribunal, en el despacho profesional y en la literatura. Es obvio que el hallazgo del fallo judicial, como también el que una opinión logre imponerse en la literatura, se lleva a cabo normalmente por la vía de un discurso. Esto sugiere, en efecto, exponer las fundamentaciones jurídicas como formas de argumentación y cadenas de argumentación» (Larenz, pág, 507; la cita que trae la nota 29, supra, es continuación de lo transcrito aquí). Todo lo cual está muy relacionado con el asunto de la tópica (supra, nota 31): «Lo que Viehweg anticipa, en la misma época en que lo hacen también otros autores [sobre todo Perelman] con matices diversos, es la perspectiva argumentatvia, la idea de que es en el contexto de cada situación donde se ponen las bases para la decisión correcta, a través del intercambio de razones. Y los propios contornos de la situación se expresan mediante la acción comunicativa entre los sujetos. Se trataría en todo ello de un proceso retórico, marcado por la inexistencia de verdades apodícticas que puedan fundar una solución indiscutible, y abocado, 
mucho más allá del conformismo tipo Perelman (o el de Kriele, etc.), se consigue poner mejor de relieve variadas pautas que subyacen a los discursos jurídicos reales y, además, se llegan a delinear esquemas de lógica material -modelos de razonamiento argumentativoque podrían hacer, debidamente manejados, que esos discursos alcanzasen otra coherencia y llegaran a ser más intersubjetivos. Alexy, por ejemplo, ha indicado criterios para una racionalidad argumentativa «procesal» del discurso práctico, y en particular el del derecho, donde la intersubjetividad sea incrementada, hasta donde resulte prácticamente posible, por medio del procedimiento en cuestión;"g esos procedimientos

por tanto, a la permanente construcción y reconstrucción de soluciones meramente plausible. Y la tópica sería el auxilio principal del que las partes en ese proceso dialógico pueden servirse como fuente de sus argumentos, de esas razones sobre cuya discusión se asentará la decisión» (García, pág. 178). De todos modos, tampoco hay que perder de vista que, en la literatura especializada, el término «argumentación» se emplea de acuerdo con sentidos de lo más variados: cfr. Struck, Zur Theorie... vid. también infra, el punto 2 del Apéndice.

${ }^{\mathrm{g}}$ «De acuerdo con esta teoría (la teoría del discurso racional), un enunciado normativo es correcto o -presuponiendo una teoría liberal de la verdad- verdadero cuando puede ser el resultado de un determinado procedimiento, es decir, el del discurso racional. La relación entre corrección y procedimiento es característica de todas las teorías procesales. Si $a$ es el representante de una teoría procesal que ha de ser construida sobre el procedimiento $P$, a la pregunta acerca de si un enunciado normativo $N$ es correcto responde diciendo:

D: un enunciado normativo $N$ es correcto si, y sólo si puede ser el resultado de un procedimiento $P$.

Dentro del marco de las teorías procesales hay muy diferentes formas de presentación de $P$. Las diferencias pueden clasificarse según que se refieran (i) a los individuos que participan en el procedimiento (ii) a las exigencias que se imponen al procedimiento. De la manera cómo sea estructurado el procedimiento con respecto a los individuos y a las exigencias del mismo depende(iii) la peculiaridad del proceso de decisión» (Alexy, La idea..., págs. 44-45). [Además de Alexy, al parecer -no he podido ver sus escritos- son Aulis Aarnio (Finlandia) y Aleksander Peczenick (Polonia-Suecia) los autores que en la actualidad trabajan con mayor resonancia internacional en esa dirección, sin perjuicio de diferencias en los acentos de sus respectivas investigaciones y bases teoréticas. Para hacerse una idea del presente estado de la discusión teorética en la materia, se puede cfr. el panorama que al respecto ofrece Kravietz, pero sobre todo dos compilaciones (que tampoco he podido consultar): Rechtstheorie, Beiheft I(1979), Berlín; y Werner Krawietz/Robert Alexy(comps.), Metatheorie juristischer Argumentation (Metateoría de la argumentación jurídica), Berlín, 1983. La idea central de todas las teorías argumentativo-procesales sobre lo racional o lo razonable, puede resumirse tal vez así: «Cuando es precisamente el contenido de la decisión lo que es objeto de disputa, el respaldo máximo que aquélla puede pretender radica en la aceptación por los litigantes o por el medio en general, sentado que no existe una fuente que imponga por sí sola contenidos para la decisión. Y la única manera de que tal reconocimiento 
podrían tal vez constituir, estandarlzados, un ejemplo de métodos (en el sentido propuesto aquí: supra, $\mathrm{X}$ in fine) para el derecho. Por otro lado, aunque trabajando en dirección metodológica distinta, Priester y Opp han mostrado cómo unos conocimientos de ciencias analíticas podrían ser fructíferos para el derecho. ${ }^{\mathrm{h}}$ Cfr., además, las valiosas indicaciones contenidas en estudios como los de Albert -racionalismo crítico- y Koch -Filosofía del lenguaje común-; o véase, por ejemplo, ya los implacables análisis de Alf Ross en su clásico libro Sobre el derecho y la justicia (trad. de Genaro R. Carrió, Eudeba, Buenos Aires, 1963).

Tipo III. -Queda la duda de si, dadas las funciones político-ideológicas del derecho, y también por los fuertes intereses gremiales de inercia intelectual en que viene a hacerse efectiva la formación universitaria tradicional impartida a sus profesionales, el someterse a unos métodos como los del tipo II pudiera llegar a ser realmente aceptado y puesto en práctica por parte de éstos. El tercer tipo de estudios no parece dar lugar a que se alimente mucha ilusión en tal sentido. Lo racional, para esos estudios, no está en el discurso jurídico analizado ni en algún modelo sustitutivo. No tratan de legitimar el actual nivel de razonamientos del derecho, ni proponen otros medios más adecuados que los vigentes para lograr que él alcance mayor racionalidad, sino que sobre todo se dedican a sacar a la luz su falta de racionalidad, la de ahora y la de siempre. Quiere decir que la

pueda tener lugar de modo que quepa llamarlo racional, es arbitrando un procedimiento argumentativo en el que las partes expresen con libertad sus argumentos y contraargumentos. (...) Existirían ciertos postulados de toda discusión racional, entre los que destacan determinadas obligaciones comunicativas que los dialogantes han de asumir, de modo que no cabe hablar de una fundamentación suficiente cuando no se respetan esos principios argumentativos» (García, págs. 178-179).

${ }^{\mathrm{h}}$ Estudios de orientación analítica han demostrado su pertinencia no sólo para discutir cuestiones de la metodología jurídica en general, sino también al abordar el examen de puntos específicos a que se aplica el razonamiento de los juristas, e incluso de problemas concretos que se solucionan (mal) en la práctica habitual del derecho. Es el caso, justamente, del libro de Opp; también se puede cfr. por ejemplo, Koch (Juristische Methodelenlehre...: op. cit. supra, nota 7 in fine) y Eike v. Savigny et. al. [Claro que dentro de la corriente analítica caben, a su vez, tipos de aproximación diferentes. Así, por ejemplo, mientras que lo que Opp propone principalmente es que también los juristas saquen provecho de conocimientos ofrecidos por la sociología empírica, Priester (Ratiotialilät und Normkritik) dirige sobre todo su atención más bien hacia una serie de condiciones formales para llevar adelante la discusión capaz de fundamentar racionalmente unas decisiones como las jurídicas.] 
racionalidad de estos exámenes consiste, precisamente, en poner de relieve la no-racionalidad del discurso examinado, o sea, que se ubican en el extremo opuesto al Tipo I. Tal falta de racionalidad del discurso profesional de los juristas, así puesta de manifiesto, se ve -a través de dichos exámenes- que no es casual ni contingente, sino que ella tiene mucho que ver con la circunstancia de que ese discurso también desempeña de hecho, sean cuales fueren las posiciones subjetivas de sus protagonistas, unas funciones de retórica y de aseguramiento de la ideología político-social dominante. Por eso él no es, ni puede ser, un pensamiento de carácter científico (propiamente) respecto a las cuestiones que allí están en juego: cfr., por ejemplo, los pormenorizados análisis de Lautmann y Schreckenberger -y vid. también Frank, como antecedente-.

El estudio que antecede a este Postscriptum se ubica más bien en el marco del Tipo II. Podría considerarse que dicho trabajo ofrece, tal vez, una especie de propedéutica para fundamentar y alentar, de manera muy general, la introducción de verdaderos modelos de racionalidad en el derecho; modelos que, para sus diseños concretos, son remitidos a la creatividad de otros autores (supra, X in fine). Sin embargo, siempre manifesté mucha reserva respecto a la viabilidad político-social de tales modelos, ${ }^{i}$ supuesto que fueran elaborados. De mi parte, el señalamiento de la (mera) viabilidad técnico-intelectual de unos métodos científicos propiamente dichos para aplicarlos a cuestiones del derecho, estuvo menos motivado por la ilusión de lograr que en realidad fuesen adoptados por los juristas, que por un propósito de ilustración crítica sobre los «saberes» jurídicos. ${ }^{j} \mathrm{Y}$ con el correr de los años, mi escepticismo no ha ido sino en aumento, de modo que hoy no le reconozco mucha importancia real al papel que la racionalidad (en sentido propio) y el método (idem) puedan desempeñar, en la práctica, para materias como el derecho. Creo, más bien, que tiene razón Holmes en el famoso pasaje donde advertía, ya en 1881, que:

«La vida real del derecho no ha sido [cuestión de] lógica: ha sido experiencia. Las necesidades sentidas de la época, las teorías políticas y la moral dominantes, las intuiciones

${ }^{i}$ Véase la nota 40, supra. Cfr. también, en mi estudio Ciencia jurídica..., el \# III. 2 in fine y el punto (viii) de las Conclusiones Generales, y vid. aquí el Anexo.

${ }^{\mathrm{j}}$ En el estudio indicado en al nota anterior, cfr. el punto (vii) de las Conclusiones Generales. 
acerca de las líneas de conducta pública, declaradas o inconscientes, incluso los prejuicios que los jueces comparten con sus conciudadanos [todas esas cosas], han tenido que ver mucho más que el silogismo en la determinación de las normas por las que los hombres deban ser gobernados». ${ }^{\mathrm{k}}$

Y lo cierto es que los más sofisticados metodólogos del discurso jurídico, sobre todo entre los del tipo II, también ellos pertenecen a ese tipo de científicos de quienes Hermann Lotze decía:

«afilan más y más sus cuchillos [métodos], pero no se preocupan de qué cortan.»

En efecto, a pesar de toda la pedantería que se despliega en modernos estudios de metodología jurídica, lo que nos proponen resulta no menos inofensivo -aunque, desde luego, es mucho más complicado- que los caminos de los métodos tradicionales. Así como no son éstos, tampoco son aquéllos quienes nos suministran lo que, ¡de hecho!, resultará determinante para ver a qué soluciones se llega frente a las cuestiones problemáticas, o sea, en casos donde se discute realmente la «verdadera» respuesta del derecho. Un autor como Kelsen (por ejemplo), tan «superado», vio mucho más a fondo en todo eso. A pesar de su obsesión por el rigor metodológico (más bien: ¡precisamente por respeto a esto!) no cayó en la ingenuidad, o la disimulación, de pretender extenderlo inclusive a la práctica misma de los juristas cuando aplican el derecho. A él no se le escapó que lo principal de este discurso, las interpretaciones, no es asunto de racionalidad científica sino de ideologías y presiones sociales. Por eso mismo, creo que lo fundamental, para que un sistema de derecho funcione lo mejor posible, tiene mucho menos que ver con el rigor metodológico -imposible de imponer en la práctica- que con un principio como el siguiente:

«para el progreso del conocimiento [y también para la correcta aplicación de éste], a veces importa más el lograr

\footnotetext{
${ }^{\mathrm{k}}$ Oliver Wendell Holmes, The Common Law, 1881, pág. 1 («The actual life of the law has not been logic: it has been experience. The felt necessities of the times, the prevalent moral and political theories, intuitions of public policy, avowed or unconscious, even the prejudices which judges share with their fellow-men, have had a good deal more to do than the syllogism in determining the rules by which men should be governed»); cit. por Dewey, pág. 21 .
} 
establecer unas condiciones institucionales y motivacionales que recompensen suficientemente el comportamiento constructivo-crítico en la solución de los problemas, que enseñar una metodología que, aunque en sus aspectos esenciales es fácil de entender [isuponiendo que lo sea!] empero resulta, llegado el caso, difícil seguirla.» (Albert, Traktat über rationale Praxis, pág. 59 -cursivas mías, E. P. H.-).

Pero deseo subrayar que mi desconfianza, si así puede llamársele, hacia la racionalidad y el método, no se refiere al empleo de ellos como vías para efectuar análisis de realidades sociales o de formas de pensar existentes; por ejemplo, para examinar el contenido semántico de los discursos del derecho y las funciones sociales de éste. Por el contrario, para esos efectos (conocimiento), pienso que son las vías más recomendables, cuando están disponibles, y no menos respecto al derecho que acerca de otras cosas. Más aún: no hay por qué descartar, y hasta es probable, que también dichos conocimientos puedan ejercer alguna influencia en el razonamiento de los jueces, si éstos recibieran ese tipo de enseñanza, y siempre que no intervengan presiones sociales lo bastante fuertes como para obstaculizar su limpia aplicación a tales o cuales tipos de casos. Téngase presente que, aun cuando el conocimiento jurídico de dicho tipo, precisamente por ser una ciencia básica, no persigue fines prácticos directos (pues la investigación básica de ciencia alguna se dirige, en sí misma, a tales fines); esto no quiere decir que aquél no pueda llegar, eventualmente, a tener también derivaciones prácticas, y sobre todo si hay operadores del derecho que quieran (y tengan el talento como para saber) utilizar esas bases teoréticas con vistas a solucionar cuestiones del discurso jurídico común. Por lo demás, si se entiende que tal discurso es una ciencia, y entonces pertenecería al género de lo que se llama las ciencias aplicadas, no podría serlo sino en cuanto, como toda ciencia aplicada, se funda en (resulta de) cierta ciencia pura, básica. Mas esta última, por su propia naturaleza, consiste en un sistema de conocimientos de los cuales sólo algunos aspectos -que de antemano nunca se sabe cuáles serán- se aprovechan por parte de la o las respectivas ciencias aplicadas. [Sobre todo esto, cfr. Bunge, págs. 206 y 216 y sigs.]

A falta de una ciencia básica, o si ésta es poco rigurosa y más bien implícita que explícita, también la ciencia aplicada de que se trate sufre las consecuencias, es de «baja calidad» (Bunge, pág. 206). Cuando la ciencia aplicada no se corresponde con una buena ciencia básica se nota que, en la práctica misma, aquélla 
deja que desear hasta en cuanto al cumplimiento de sus meros cometidos utilitarios, por lo menos en algunos respectos. Esto es también verdad para el derecho, por supuesto. De ahí que, aunque su ciencia básica (Rechtsgrundlagepforschung) no tiene muchas posibilidades reales de ser verdaderamente tomada en cuenta por lo general en la práctica jurídica, dadas las condiciones ideológicas y las presiones sociales bajo las cuales ésta transcurre, no menos cierto es que sólo aquélla -jno la dogmática corriente!- es capaz de hacer del derecho un auténtico conocimiento en el plano de la razón práctica y, así, abrir la posibilidad inclusive de que algunos juristas lleguen a sacar provecho de él para mejorar (si los dejan) su discurso profesional. En síntesis: si bien la cuestión de su trascendencia práctica no es decisiva para juzgar sobre la corrección racional de un estudio científico del derecho, tampoco es imposible que él hasta pueda tener alguna trascendencia también en el plano práctico real, llegado el caso, si las circunstancias -entorno social, preparación científica de los operadores del discurso jurídico- lo permiten. Empero, no hay que engañarse, es poco probable que esto último resulte lo habitual.

En lo que no creo para nada, eso sí, es en la trascendencia práctica, y ni siquiera en la fertilidad teorética, de ciertos criterios «técnicos» que, inspirados en el mero afán de ser metódico, al fin de cuentas no van más allá del palabrerío pedante que disimula los problemas reales o, todavía peor, puede servir para legitimar que éstos sean tratado mediante unos corsets burocráticos-tecnocráticos que esterilizan la inteligencia. Lo que así se consigue, en definitiva, no es otra cosa que contribuir a que dichos problemas NO se enfrenten con esa actitud «constructivo-crítica» que menciona Albert. ${ }^{1}$ Una cosa es ahogar porque se logre, pero sólo en la medida de lo verdaderamente posible, alcanzar conocimiento racional y metódico sobre las cosas. Otra, muy distinta, tratar de imponer a rajatabla cualquier método, por más científico que sea -supongamos que lo es-, para manejar un discurso acerca de ciertos problemas reales. ¡No siempre

${ }^{1}$ Por ejemplo, respecto a la intervención de tales «técnicas» en los planes de estudio de la Universidad de Costa Rica, y particularmente acerca de la escuela de hipocresía que en cuanto método de enseñanza constituyen las llamadas «investigaciones» que establece el currículum de la Facultad de Derecho, cfr. Enrique P. Haba, «De la fantasía curricular (y sobre algunas de sus precomprensiones tecnocráticas)», en Revista de la Facultad de Derecho, núm. 56 (mayo-agosto 1986), Universidad de Costa Rica/Facultad de Derecho-Colegio de Abogados, San José. 
es lo mismo «manejar» algo, en un lenguaje, que resolverlo, en la práctica! También para el campo de la metodología del derecho es muy cierto, y en la actualidad más que nunca, lo de que:

«Como escribió Kenneth E. Boulding en The Image, hay en el mundo mucha gente que cree que 'la ciencia casi pudiera definirse como el proceso de sustituir por cuestiones sin importancia, a las que puede responderse, cuestiones importantes, a las que no se puede'.» (Dubos, pág. 141.) [Cfr., p. ej., el punto 1 del Apéndice, infra.]

Sin embargo, hasta una conclusión tan cautelosa como la ofrecida aquí, en el sentido de que sólo como modelo intelectual es viable una verdadera ciencia del derecho, acaso podría ser objetada si se atiende, por ejemplo, a razones como las que Frank presentó hace más de medio siglo (de las que, por supuesto), no se han llegado a enterar nuestros juscientistas actuales). Frank llama la atención acerca de dos verdades que casi siempre son pasadas por alto, tanto en el pensamiento jurídico común como en los proyectos cientificistas para el derecho. A saber: la doble indeterminación de que éste se halla inevitablemente afectado, por el lenguaje mismo de los juristas y por la inconmensurable fluidez de la realidad en que ese discurso se inserta -realidad de la que forman parte hasta los propios juristas, pues también «los jueces son humanos»-. En efecto, Frank no permite que nos olvidemos de que:

«... el derecho, tal como lo tenemos, es incierto, indefinido, sujeto a incalculables cambios (...) El derecho siempre ha sido, lo es ahora y siempre continuará siendo, ampliamente vago y variable. ¿Y cómo podría ser de otro modo? El derecho se ocupa de relaciones humanas en sus más complicados aspectos» (Law..., págs $5 \mathrm{y}$ $6)$.

Quiere decir que no puede haber discurso jurídico seguro, esto es, unos criterios de derecho netos que se hallen pre-establecidos (cfr. Mr. Justice...). Porque, inclusive en el caso de que se lograra mejorar al máximo la precisión de los términos mismos de ese discurso y vincularlo al máximo con los conocimientos disponibles de las ciencias sociales -posibilidad intelectual señalada en nuestro estudio-, eso no impediría que, de todas maneras, 
la variedad y movilidad (siempre altamente imprevisibles) de los casos a que él se aplique haga que, por lo general, resulte imposible llegar a saber de antemano las soluciones que éstos recibirán en manos de los jueces. Por ende: la fijeza, la «seguridad» del derecho, jamás podrá ser otra cosa que un mito, dice Frank.

No tengo inconveniente, por mi parte, en reconocer que tales observaciones son acertadas. En todo caso, lo son para una buena parte del derecho, precisamente la que llega a discutirse en los tribunales. No obstante, aun dando por admitido que las soluciones judiciales no se puedan prever con seguridad, eso no descarta que el procedimiento para obtenerlas puede ser más o puede de ser menos intersubjetivo, en función del tipo de discurso empleado para arribar a ellas. Por eso, lo que aquí se sostuvo no es que el discurso jurídico pudiera ser elaborado, en general, como una ciencia en sentido estricto, sino que cabría ajustarlo a condiciones que hagan de él una ciencia en sentido amplio; vale decir, formularlo de manera tal que sus razonamientos fuesen relativamente menos azarosos y subjetivos, sus soluciones menos a-metódicas. Aunque esto no lo transformaría, por cierto, en una ciencia completamente segura y cuyos resultados sean todos previsibles, al menos disminuiría en algo su actual coeficiente de incerteza, y sobre todo prevendría el ocultamiento de las verdaderas razones que determinan lo que allí se resuelve. En síntesis: considero que no toda ciencia del derecho es cosa imposible (intelectualmente), pues el discurso jurídico podría ser mejor desde el punto de vista científico; y si bien es cierto que ni siquiera un discurso «mejor» le proporcionaría a aquél la seguridad que tiene el discurso (normal) de las ciencias naturales, no me parece que sea indiferente el que, por lo menos, el razonamiento de los Juristas consiguiera alcanzar el mayor grado posible de intersubjetividad científica. Esto es, que fuera mucho menos retórico e ideológico de lo que suele ser. [Pienso que Frank estaba de acuerdo con esto último (por ejemplo, cfr. su Apéndice II, op. cit.); sólo que él no lo vinculó a unos mejores métodos para el discurso en cuestión, ni creía que fuera precisamente tal cosa lo que pudiera hacerlo menos inseguro (cfr. su Apéndice X, punto 3).]

Frank insiste, además, en que semejante afán de certeza no es otra cosa que el producto de un «infantilismo» en nuestros modos de pensar (childisch thought-ways: cfr. Law..., caps. II, VIII, IX y passim). Es una reminiscencia de nuestra fe de niños en la autoridad paterna, lo cual se manifiesta en muchos campos, inclusive en la ciencia: 
«Pues, funcionalmente, el derecho visiblemente se parece al Padre-como-Juez. El Padre-como-Juez, del niño, era infalible. Sus juicios y mandatos parecían poner orden en el caso de los conflictivos puntos de vista concernientes a la conducta correcta. Su ley parecía absolutamente cierta y previsible. (Por supuesto, el derecho y la religión no son las únicas actividades afectadas por la búsqueda de la autoridad paterna. También la ciencia padece cuando se la hace cargar con el fardo de ser una garantía completa de la certeza cósmica.)»(op. cit., pág. 21 con su nota 6; cfr. también $M r$. Justice..., págs. 582 y sig.).

Es eso lo que da origen, así como a otras cosas (religión, etc.), a que el pensamiento jurídico se presente sujeto a un «mito básico» (basic legal myth: cfr. Law..., cap. I y passim): el de

«que el derecho es, o puede hacerse que sea, inmóvil, fijo y determinado (unwaverign, fixed and settled)» (página 21). «Los juristas no sostienen meramente la vulgar noción de que el derecho es susceptible de ser hecho completamente estable e invariable; parecen estar inclinados a crear la impresión de que, en total, desde ya él es una cosa establecida y cierta» (pág. 8). «Obsérvese los argumentos de los abogados al dirigirse a los tribunales, o hasta las opiniones de los tribunales mismos: están formulados como si a las decisiones correctas se llegara por deducción lógica a partir de un cuerpo preciso y preexistente de reglas jurídicas. Raramente los jueces revelan que haya elementos contingentes en su razonamiento, alguna duda o lagunas para estar plenamente convencidos» (pág. 9).

Y Frank se pregunta:

«¿Por qué la generalidad de los juristas insiste en que el derecho debe y puede ser conocible claramente y predecible en forma precisa, aunque al hacer eso justifican la popular creencia en un absurdo patrón de exactitud jurídica? (...) [Empero] sólo un limitado grado de certeza jurídica puede alcanzarse. (...) Si es verdad que se persigue una mayor certeza jurídica que la que es prácticamente requerida y alcanzable, entonces la exigencia de excesiva estabilidad jurídica no proviene de necesidades prácticas. Ella tiene que tener sus raíces no en la realidad, sino en un afán por algo irreal» (págs. 11 y 12). 
Afán (a yearning) que se explica, según Frank, justamente por la mencionada ansia -subconsciente- de hallar también en el derecho un sucedáneo de la infalible autoridad paterna (cfr. esp. el cap. II), mas sin excluir tampoco la presencia de otros factores explicativos (cfr. el Apéndice I, op. cit.).

Sin embargo, aunque esa reconducción del afán de seguridad (¡también el mío!) a resabios de una idealizada imagen paterna es un elemento de explicación -junto a otros: ideologías, protección del status quo, etc.- muy plausible, esto no significa que dicho afán tenga que ser considerado necesariamente como algo que deba y pueda ser eliminado. Si bien se mira, la crítica de Frank no se dirige tanto contra el afán en sí mismo, sino contra las falsas ilusiones, los autoengaños que él contribuye a engendrar (por ejemplo, cfr. op cit., págs. 12 [nota 9 in limine] y 171). Cabe pensar que, en cambio, en la medida en que para éste pudieran hallarse formas de satisfacerlo que sí fueran viables en la realidad (y suponiendo, claro, que eso no va en perjuicio de otros objetivos humanos valiosos), en esa medida no tendría por qué estar mal, sino todo lo contrario, hacer lo posible por alcanzar seguridades. Pues bien, el tipo de certezas -intersubjetividad y eficacia- que persiguen los métodos científicos, sea cual fuere la génesis psicológico-individual y social por la cual ello se considera digno de ser obtenido, es algo que logra cumplirse en la realidad, por lo menos hasta cierto punto, precisamente por la práctica misma de las ciencias. La tesis sostenida en nuestro estudio es que tal tipo de certeza podría ser incrementado sensiblemente en la ciencia jurídica también: en el sentido de que entonces los resultados a que se llegue en las sentencias, y aunque muchas veces no fuera posible saberlo de antemano, estarían intersubjetivamente fundados, porque -a diferencia del pensamiento jurídico tradicionalesos resultados surgirían allí de unos procedimientos verdaderamente metódicos. Desde luego que, así y todo, es probable que la ciencia jurídica no obtuviera los niveles de certeza que se alcanzan en la práctica normal de las ciencias naturales; pero entonces, al menos sus resultados tendrían la mejor fundamentación posible, la de las ciencias sociales avanzadas. $\mathrm{Y}$ si de esa manera no se consigue obtener, en definitiva, un grado de previsibilidad de las decisiones judiciales mucho mayor que el actual, en todo caso se conseguiría, eso sí, liberar el pensamiento jurídico de las ficciones que señala Frank y hacerlo beneficiario de los conocimientos científicos disponibles. Si no en homenaje al afán de seguridad, al menos por un afán de veracidad y de transparencia intelectual, valdría la pena tratar de sujetar el pensamiento jurídico a toda la racionalidad y 
el método que siempre le han faltado. Bien leído, de un libro tan despiadadamente realista, y tan fermental, como el de Frank, no pueden sino extraerse muchos motivos más (que los por mí expuestos) para desear que el pensamiento de los juristas aceptara ser enderezado en tal dirección.

Por otro lado, a Frank tampoco se le escapó que algo análogo al «mito jurídico básico» consigue infiltrarse también, y por razones similares («infantilismo»), incluso en el pensamiento relativo a las ciencias más adelantadas (cfr. op. cit., su cap. XV y esp. el Apéndice III titulado «Ciencia y certeza: una acientífica concepción de lo que es la ciencia»). Basta con pensar, acotaría yo, en la abrumadora difusión y predominancia que en la actualidad tienen los mitos tecnocráticos, en todas las esferas, para advertir cuánta razón tenía Frank al subrayar que:

«Por supuesto, esa es una acientífica (unscientific) concepción [acerca] de la ciencia. La ciencia, así falsamente concebida, se transforma, en efecto, en otro sustituto del padre, un garante de esa certeza absoluta que el niño anhela y que el hombre cabalmente adulto reconoce como infantil. Una concepción científica de la ciencia rechaza tal infantilismo» (op. cit., pág. 307).

También en esto, el estudio de Frank se revela, en mucho de su aproximación, asombrosamente actual, en la línea de la más moderna epistemología de las ciencias (Popper, Kuhn y otros -cfr., por ejemplo, el penúltimo párrafo de la pág. 105, op. cit.-). Esa «unscientific conception» tiene mucho que ver con lo que en otro sitio he llamado fideísmo cientista. Y me importa sobremanera efectuar una aclaración final, precisamente a este respecto. ${ }^{\mathrm{m}}$

${ }^{\mathrm{m}}$ Lo del «fideísmo cientista», y porqué el derecho difícilmente pueda dejar de ser una «'ciencia' en sentido AMPLÍSIMO», lo explico un poco más en el Postscriptum que se incluye en la última versión del estudio ya mencionado en las notas (i) y (j): cfr. infra, el Anexo. Vid. también el punto 1 del Apéndice. [He preferido detenerme en los puntos de vista de Frank, en vez de seguir a autores que están de moda, pues cada vez estoy más convencido de que la Teoría del Derecho reciente -digamos: la posterior a 1970- no agrega nada sustancial, como no sea unas esforzadas sobredosis de variada pedantería, a lo que en líneas generales ya se sabía antes. De ahí que, venir a leer en 1989 (tal es mi caso) un libro como el de Frank, es respirar aire fresco en medio de tanto hollín terminológico y mero detallismo que nos abruman en los congresos de filosofía jurídica y en las revistas especializadas de la materia; esto, sin perjuicio de reconocer que también hay estudios actuales que tienen su interés, en cuanto sirven para divulgar o para redondear aspectos del conocimiento teorético previo, aunque siempre sigue siendo más ilustrativo leer directamente a los grandes autores. Ese no-tener-nada-sustancial-que-agregar, desde luego que pasa desapercibido (o, sencillamente, no 
El fideísmo cientista, que hoy aparece consagrado sobre todo en la ingenua confianza hacia la teología de la computación como arréglalo-todo, reposa en la fe de que cualquier asunto tiene una solución metódico-científica; y también, implícitamente, en la creencia de que cualquier solución de ese tipo -y cuanto más burocratizable, mejor- será preferible a toda solución menos «técnica». ¡Pero es eso, justamente, lo que NO quisiera ver sugerido por el estudio que he presentado! Menos que menos, respecto al derecho. Pues lo cierto es que éste, por el papel que sus discursos juegan en la dinámica social, nunca será una verdadera ciencia (en sentido estricto). Allí lo decisivo son, más que nada, las «condiciones institucionales y motivacionales» (Albert), y las «culturales» en general (Häberle), ${ }^{\mathrm{n}}$ que determinan realmente la conducta de sus actores, incluidos los juristas como operadores profesionales de dichos discursos. Lo cual no quita que ciertos exámenes racionales acerca de estos discursos, al poner de manifiesto precisamente toda la falta de racionalidad y de método que caracteriza al pensamiento habitual de los juristas, ${ }^{\tilde{n}}$

importa) para quienes, más que toda otra cosa, les obsesiona la cuestión de «estar al día», vale decir, se contentan con apreciar, por ejemplo, ciertas minuciosidades técnicas que sirven como embalaje a muchos de los nuevos estudios. Por contraposición, es también eso mismo lo que explica el éxito que han obtenido, por ejemplo, Rawls y Dworkin: simplemente, porque éstos sí tienen «algo» que decir. Éxito para el que no ha sido óbice, por eso, que en el caso del primero su famoso libro consista, básicamente, en unos juegos escolásticos del «raciocinar»; y en el del segundo, que allí asistamos a la reformulación de tesis que, aunque él las defiende con ingenio, básicamente significan recaer en planos de ingenuidad pre-Frank acerca del pensamiento jurídico- y particularmente respecto al lenguaje, quedarse en un nivel de análisis que es pre-Ogden/Richards, pre-Stevenson, pre-Wittgenstein, o hasta pre-Morris, etc.]

${ }^{\mathrm{n}}$ Ya Herman Heller había señalado que «La Teoría del Estado es ciencia cultural y no ciencia natural» (Teoría del Estado. Parte I, apartado II.2). En nuestros días, es particularmente el constitucionalista alemán Peter Häberle quien ha insistido, una y otra vez en sus publicaciones de los últimos años, en que los textos de la Constitución -y, a partir de ahí, el derecho positivo en generaldeben, y no pueden sino, ser entendidos como un precipitado cultural. Cfr. esp. su escrito programático Verfassungslehre als Kulturwissenschaft (Teoría constitucional como ciencia cultural), Duncker \& Humblot, Berlín, 1982.

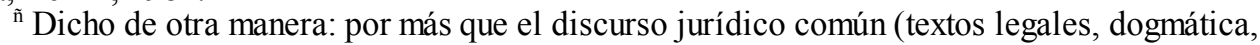
jurisprudencia) no sea muy racional, ese discurso -tomándolo como lenguaje-objeto- puede ser examinado (críticamente) en otro discurso -metalenguaje- que, éste sí, no tenga tales defectos de racionalidad; cfr., en mi estudio sobre Ciencia jurídica..., el \# III.2. También para el derecho, 
además contribuyan a despejar el camino hacia una más realista apercepción de las susodichas condiciones. Así, algunos estudios del Tipo II se pueden tomar también como una dilucidación preliminar o concomitante con respecto a los del Tipo III; y es ése, según pienso, el interés que tal vez puede tener el trabajo aquí ofrecido.

como en otros campos, la falta de racionalidad del lenguaje-objeto no tiene por qué contagiarse necesariamente a sus metalenguajes. [Esta distinción de planos -una cosa es el discurso del Derecho como actividad profesional o política, otra el de la Teoría General del Derecho como un metadiscurso donde aquél es analizado científicamente- no la señalé de manera explícita en el trabajo presentado acá. De ahí que éste adolezca de cierta ambigüedad en el uso del término «derecho» -o: «discurso jurídico», «pensamiento de los juristas», etc.-; pero tal vez el contexto de la exposición logre salvar confusiones, por lo menos en cuanto a las ideas fundamentales. Y además, aun sin mencionar esa cuestión de planos del lenguaje, está el hecho de que cabe una pluralidad de ciencias acerca del derecho: supra, VIII in fine (Excurso).] 


\section{LITERATURA ESCOGIDA ${ }^{1}$}

** Albert, Hans, Traktat über kritische Vernunft, J. C. B. Mohr (Paul Siebeck), Tübingen,

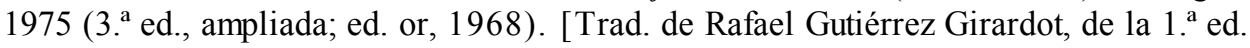
Tratado sobre la razón crítica, Sur, Buenos Aires, 1973, 260 págs.]

* Albert, Hans, Traktat über rationale Praxis (Tratado sobre la práctica racional), J. C. B. Mohr (Paul Siebeck), Ubingen, 1978, XI + 193 págs.

** Alexy, Robert, Theorie der juristischen Argumentation (Teoría de la argumentación jurídica), Suhrkamp, Francfort, 1978.

- Alexy, Robert, «La idea de una teoría procesal de la argumentación jurídica», en Derecho y Filosofía (comp. Ernesto Garzón Valdés, trad. de Carlos de Santiago), págs. 43-57, Fontamara 50, México, 1988.

- Anacker, Ulrich, «Vernunft» (Razón), en Handbuch philosophischer Grundbegrffe (Manual de conceptos filosóficos fundamentales), comp. por Hermann Krings, Michael Baumgartner y Christoph Wild, t. VI, págs. 1597-1612, Kösel, Munich, 1974. [Hay trad. al castellano de este Manual, publicada en España.]

- Apel, Karl Otto; Gadamer, Hans-Georg; Habermas, Jürgen, et. al., Hermeneutik und Ideologiekritik (Hermenéutica y crítica de la ideología), Suhrkamp, Francfort, 1971, 316 págs.

* Archives de Philosophie du Droit, t. 23, Formes de rationalité en droit, Sirey, París, 1978.

${ }^{1}$ Para una enumeración más amplia de trabajos sobre la temática aquí tratada, cfr. en las notas, supra, y sobre todo la bibliografía que se ofrece en Haba, Rationalité (págs. 337-338). Vid. también las valiosas bibliografías específicas por temas que brinda Arnaud: cfr., por ejemplo, su sección 0200 (pág. 35), «Raison et droit». En la presente lista se incluyen únicamente trabajos de autores mencionados, sea en el texto o en notas, a lo largo del estudio ofrecido (cfr. supra, nota 1 in limine); pero en dicho estudio, como así también en el Postscriptum y en el Apéndice, se mencionan además otras obras que, por ser menos fundamentales para nuestra temática central, no aparecen incorporadas a esta lista; se resaltan mediante asteriscos aquellos trabajos que son especialmente relevantes en consideración a los desarrollos presentados aquí. 
* Arnaud, André-Jean, Critique de la raison juridique, Tome I Où va la sociologie du droit?, L. G. D. J., Pars, 1981, 468 págs.

- Atienza, Manuel, Introducción al Derecho, Barcanova, Barcelona, 1985, XII + 377 págs.

* Atienza, Manuel, «Para una razonable definición de 'razonable'», en DOXA Cuadernos de Filosofía del Derecho, 4 (1987), págs. 189-200, Centro de Estudios Constitucionales y seminario de Filosofía del Derecho de la Universidad de Alicante, 1987.

- Batiffol, Henri, «Questions de l'interprétation juridique», en Archives de Philosophie du Droit, vol. XVII (1972), págs. 9-27.

** Blanché, Robert, Le raisonement, PUF, París, 1973, 264 págs.

- Bochenski, 1. M., Die zeitgenössischen Denkmethoden, Francke (UTB 6), Berna, Munich, 1975 (7. ${ }^{\text {a }}$ ed.). [Trad. (muy defectuosa) de Raimundo Drudis Baldrich, Los métodos actuales del pensamiento, Rialp, Madrid, 1975 (10. ${ }^{a}$ ed.), 280 págs.]

- Bobbio, Norberto, «Scienza del diritto e analisi del linguaggio», en Rivista Trimestrale di Diritto e Procedura Civile, año IV, núm. 2 (junio 1950), págs. 342-367, Dott. A. Giuffrè, Milán. [Trad. de Alfonso Ruiz Miguel, «Ciencia del Derecho y análisis del lenguaje», en Bobbio, Contribución a la teoría del derecho, págs. 173-200, Fernando Torres, Valencia (España), 1980.]

* Bobbio, Norberto, «La razón en el Derecho (observaciones preliminares)», en Doxa. Cuadernos de Filosofía del Derecho 2, págs. 17-26 (trad. de Alfonso Ruiz Miguel), Departamento de Filosofía del Derecho de la Universidad de Alicante, 1985.

- Brecht, Arnold, Teoría política. Los fundamentos del pensamiento político del siglo XX (trad. de Juan Manuel Mauri), Depalma-Ariel, Buenos Aires-Barcelona, 1963, XXIX, + 621 pág. [ed. or. en inglés y en alemán: respectivamente, 1959 y 1961].

- Brimo, Albert, «Logique juridique et Méthode juridique», en La logique juridique, págs. 213-223, Pedone, París, 1967.

págs.

- Bunge, Mario, Seudociencia e ideología, Alianza Editorial (AU 440), Madrid, 1985, 253

** Dewey, John: «Logical Method and Law», en Cornell Law Quarterly 10 (1924), págs. 17-27, Ithaca (N.Y.).

- Esser, Josef, Vorverständnis und Methodenwahl in der Rechtsfindung. Rationalitätsgrundlagen richterlicher Enischeidungspraxis (Precomprensión y selección del método en la obtención del derecho. Bases de racionalidad en la práctica de la decisión judicial), Fischer Athenäum (Taschenbuch 6001), Francfort, 1972 (2. ${ }^{\mathrm{a}}$ ed., con Prólogo ampliado; ed. or. 1970), 224 págs.

* Frank, Jerome, Law and the Modern Mind, Peter Smith, Gloucester (Mass.), 1970 (reproducción de la sexta ed. ampliada -ed. or. 1930-).

- Frank, Jerome, «Are Judges Human?», en 80 University of Pennsylvania Law Review (1931), págs. 17 y sigs., y 233 y sigs.

** Frank, Jerome, «Mr. Justice Holmes and Non-Euclidean Legal Thinking», en 17 Cornell Law Quarterly (1932), págs. 568-603. 
* Gadamer, Hans-Georg, Wahrheit und Methode. Grundzüge einer Philosophischen

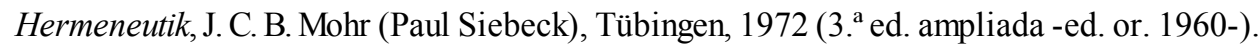
[Trad. de Ana Agud Aparicio y Rafael de Agapito, Verdad y Método. Fundamentos de una hermenéutica filosófica, Sígueme, Salamanca, 1977, 691, págs.]

* García Amado, Juan Antonio, «Tópica, Derecho y método jurídico», en DOXA 4 (1987), págs. 161-188, Universidad de Alicante.

Giuliani, Alessandro: La controversia. Contributo alla logica giuridica, Università de Pavia (Studi nelle scienze giuridiche e sociali 143), 1966, 216 págs.

* Gottlieb, Gidon: The Logic of Choice. An Investigation of the Concepts of Rule and Rationality, George Allen \& Unwin, Londres, 1968, 188 págs.

** Granger, Gilles-Gaston, La raison, PUF (Que sais-je? 680), París, 1955, 138 págs. [Hay trad. al castellano publicada por EUDEBA, Buenos Aires.]

- Haba, Enrique Pedro, Esquemas metodológicos en la interpretación del derecho escrito, Universidad Central de Venezuela-Facultad de Derecho (Cuaderno de Filosofía del Derecho 9), Caracas, 1972, 111 págs.

- Haba, Enrique P., «Rationalität der Autoritäten oder Autorität der Rationalität?» (¿Racionalidad de las autoridades o autoridad de la racionalidad?), en Rechtstheorie, vol. 8 (Cuaderno 2), págs. 145-163, Duncker \& Humblot, Berlín, 1977.

** Haba, Enrique P, «Ciencia jurídica: ¿qué ‘ciencia’?», en Revista de Ciencias Jurídicas, núm. 51 (septiembre-diciembre 1984), págs. 11-35, Universidad de Costa Rica-Facultad de Derecho-Colegio de Abogados. [Una versión anterior de este estudio apareció en el Apéndice-Tomo IV de la Enciclopedia Jurídica Omeba, págs. 124-135, Driskill, Buenos Aires, 1982, bajo el título: «Ciencia jurídica como un problema de métodos». Una nueva versión corregida y ampliada, de dicho trabajo se acaba de publicar en el núm. 12 de Ius et Praxis, revista de la Facultad de Derecho y Ciencias Políticas de la Universidad de Lima, págs. 97-125, diciembre 1988.]

- Haba, Enrique P., «Rationalité», en Dictionnaire Encyclopédique de Théorie et de Sociologie du Droit (sous la direction de André Jean Arnaud), págs. 337-340, L. G. D. J., París, 1988.

** Horak, Franz, Rationes decidendi. Entscheidungsbegründungen bei den älteren römischen Jurischen bis Labeo (Rationes decidendi. Fundamentaciones de las sentencias en juristas romanos más antiguos hasta Labeo), t. I, Scientia, Aalen, 1969, 311 págs.

- Jackson, Bernard S., Semiotics and Legal Theory, Routledge \& Kegan Paul, Londres, 1985, xii +373 págs.

- Jackson, Bernard S_ «Emerging Issues in Legal Semiotics», en Revue de la Recherche Juridique: Droit Prospectif, 1986-2, Colloque International de Sémiotique Juridique (Aix-en-Provence, 11-13 Mars 1985), páginas 17-37, Faculté de Droit et de Science Politique 
d'Aix-Marseille, Presses Universitaires d'Aix-Marseille, 1986.

* Jackson, Bernard S., «Rationalité consciente et inconsciente dans la théorie du droit et la science juridique» (trad. de Daniel Flores), en Revue interdisciplinaire d'études juridiques, vol. 1987-19, págs. 1-18.

- Jhering, Rudolf von, Broma y Veras en la Jurisprudencia, trad. de Tomás A. Banzhaf, EJEA, Buenos Aires, 1974, 425 págs.

* Koch, Hans-Joachim, «Ueber juristisch-dogmatisches Argumentierenun Staatsrecht» (Sobre la argumentación jurídico-dogmática en el Derecho Estatal), en Hans-Joachim Koch (comp.), Seminar: Die juristische Methode im Staatsrecht. Ueber Grenzen von Verfassungs-und Gesetzbindung (Seminario: El método jurídico en el Derecho Estatal. Sobre límites de la vinculación a la Constitución y a la ley), Suhrkamp (Taschenbuch Wissenschaft 198), Francfort, 1977, págs. 13-157.

- Kriele, Martin, Theorie der Rechtsgewinnung, entwickelt am Problem der Verfassungsinterpretation (Teoría de la obtención del derecho, desarrollada con referencia al problema de la interpretación constitucional), Duncker \& Humbolt, Berlín, 1977 (2. ${ }^{a}$ ed., ampliada por un postfacio), 366 págs.

- Lakatos, Imre, y Musgrave, Alan, comp., Criticism and the Growth of Knowledge (contribuciones de: Paul K. Feyerabend, Tomas S. Kuhn, I. Lakatos, Karl, R. Popper, Stephen Toulmin et. al.), Cambridge University Press, Londres, 1972 (2. ${ }^{a}$ ed., ampliada). [Trad. de Francisco Hernán, La crítica y el desarrollo del conocimiento, Introducción por Javier Muguerza, Grijalbo (Colección «Teoría y Realidad» I), Barcelona-Buenos Aires-México, 1975,523 págs.

** Lalande, André, Vocabulaire technique et critique de la philosophie (voces: Discours, Discursif, Fondement, Méthode, Méthodologie, Raison, Raisonnable, Raisonnement, Rationalité, Rationnel), PUF, París, 1968 (10. ${ }^{\mathrm{a}}$ ed.). [Trad. (de la 5. ${ }^{\mathrm{a}}$ ed.) efectuada bajo la dirección de Luis Alfonso y revisada por Vicente Quintero: Vocabulario Técnico y Crítico de la Filosofía, 2 tomos, El Ateneo, Buenos Aires, 1953.]

* Larenz, Karl, Metodología de la Ciencia del Derecho, (trad. de la cuarta ed. alemana, definitiva, de 1979) por Marcelino Rodríguez Molinero, Ariel, Barcelona, 1980, 536 págs. * Lautmann, Rüdiger, Justiz-die stille Gewalt (La Justicia-forma callada de Poder), Fischer Athenäum (Taschenbuch FAT 4002), Francfort, 1972, 207 págs.

* Moreno, Julio Luis, Los supuestos filosóficos de la Ciencia Jurídica, Biblioteca de Publicaciones Oficiales de la Facultad de Derecho y Ciencias Sociales de la Universidad de la República (Sec. III, vol. CXXV), Montevideo, 1963, 178 págs.

- Müller, Friedrich, Normstruktur und Normativität. Zur Verhültnis von Recht und Wirklichkeit in der juristischen Hermeneutik, entwickelt an Fragen der Verfassungsinterpretation (Estructura de la norma y normatividad. Sobre la relación entre derecho y realidad en la hermenéutica jurídica, con referencia a cuestiones de la interpretación 
constitucional), Duncker \& Humblot, Berlín, 1966, 232 págs.

- Müller, Friedrich, Juristische Methodik (Metodología jurídica), Duncker \& Humblot, Berlín, 1976 (2. ed., ampliada), 327 págs.

* Müller, Friedrich, Juristische Methodik und Polilisches System. Elemente einer Vefassugstheorie II (Metodología jurídica y sistema político. Elementos de una Teoría constitucional II), Duricker \& Humblot, Berlín, 1976, 127 págs.

** Opp, Karl-Dieter, Soziologie Im Recht (Sociología en el Derecho), Rororo Studium (núm. 52), Hamburgo, 1973, 265 págs.

* Otte, Gerhard, «Zwanzig Jahre Topik-Diskussion: Ertrag und Aufgaben» (Veinte años de discusión sobre la tópica: resultado y tareas), en Rechtstheorie, vol. 1 (Cuaderno 2), págs. 183-197, Duncker \& Humblot, Berlín, 1970.

- Perelman, Chaim, «Ce que le philosophe peut apprendre par l'étude du droit», en Droit, Morale et Philosophie, págs. 135-147, L. G. D. J., París, 1968.

** Perelman, Chaim, Logique juridique. Nouvelle rhétorique, Dalloz, París, 1976. [Trad. de Luis Díez-Picazo, La lógica jurídica y la nueva retórica, Monografías Civitas, Madrid, 1979, 249 págs.]

** Poirier, René, «Rationalité juridique et rationalité scientifique», en Archives de Philosophie du Droit, t. 23 (cit. supra), págs. 11-34.

- Polya, G., Mathematics and plausible reasoning, Princeton University Press, Princeton-New Jersey, 1954. [Trad. de José Luis Abellán, Matemáticas y razonamiento plausible, Tecnos, Madrid, 1966, 580 págs.

* Priester, Jens-Michael: Rationalität und Normkritik (Racionalidad y crítica de las normas), Tesis doctoral presentada en la Rechts-und Wirtschaftswissenschaftlichen Fakulatät der Universität des Saarlandes, Saarbrücken, 1972, 220 págs. (aprox.).

- Priester, Jean-Michael, «Rationalitát und funktionale Analyse» (Racionalidad y análisis funcional), en Jahrbuch für Rechtssoziologie und Rechtstheorie, vol. I, Die Funktion des Rechts in der modernen Gesellschaft (La función del derecho en la sociedad moderna), Bertelsmann, Bielefeld, 1970. [Este artículo es un extracto de la Tesis antes mencionada.]

- Rapp, Friedrich, «Methode» (Método), en Handbuch philosophischer Grundbegriffe (cit. supra), vol. IV, págs. 913-929.

- Recaséns Siches, Luis, Experiencia jurídica, naturaleza de la cosa y Lógica «razonable», FCE-UNAM, México, 1971, 578 págs.

- Röd, Wolfgang, «Grund» (Fundamento), en Handbuch philosophischer Grundhegriffe (cit.), vol. III, págs. 642-657.

- Rottleuthner, Hubert, Rechtswissenschaft als Sozialwissenschaft (Ciencia del Derecho como ciencia social), Fischer (Taschenbuch 6514), Francfort, 1973, 267 págs.

* Rüthers, Bernd, Die unbegrenzte Auslegung. Zum Wandel der Privatrechtsordnung im Nationalsozialismus (La interpretación ilimitada. Acerca de la transformación del ordenamiento de Derecho 
Privado en el nacionalsocialismo), Fischer Athenäum(Taschenbuch 6011), Francfort, 1974 (2. ${ }^{a}$ ed., ed. or. 1968), 496 págs.

* Savigny, Eike von; Neumann, Ulfrid, y Rahlf, Joachim, Juristische Dogmatik und Wissenschaftstheorie (Dogmática jurídica y teoría de la ciencia), C. H. Beck (Schwarze Reihe, núm. 136), Munich, 1976, 171 págs.

* Sbriccoli, Mario, L'interpretazione dello statuto. Contributo allo studio della funzione dei giuristi nell'età communale, Dott. A. Giuffrè, Milán, 1969, 493 págs. [Para una síntesis de las principales ideas de este libro, cfr. Mario Sbriccoli, «Politique et interprétation juridique dans les villes italiennes du Moyen âge», en Archives de Philosophie du Droit, vol. XVII (1972), págs. 99-113.

** Schreckenberger, Waldemar, Rhetorische Semiotik. Analyse von Texten des Grundgesetzes und von rhetorischen Grundstrukturen der Argumentation des Bundesverfassungsgerichts (Semiótica retórica. Análisis de textos de la Constitución y de estructuras básicas retóricas de la argumentación de la Corte Constitucional Federal), Karl Alber, Freiburgo-Munich, 1978, 450 págs. (aprox.).

** Segeth, Wolfgang, «Methode», «Methodik», «Methodisch», «Methodologie», «Methodologisch», en Georg Klaus y Manfred Buhr (comps.), Marxistisch-Leninistisches Wörterbuch der Philosophie, págs. 717-723, Handbuch Rororo (núm. 6156), Hamburgo, 1972.

* Stegmüller, Wolfgang, Einheit und Problematik der wissenschaftlichen Welterkenntnis (Unidad y problemática del conocimiento científico del mundo), Max Hueber (Münchener Universitätsreden, Nueva serie, Cuaderno 41), Munich, 1967, 22 págs.

- Stevenson, Charles, L., Ethics and Language, Yale University Press, New Haven-Londres, 1944. [Trad. de Eduardo A. Rabosi, Ética y Lenguaje, Paidós, Buenos Aires, 1971, 308 págs.]

- Ströcker, Elisabeth, Einführung in die Wissenschaftstheorie (Introducción a la teoría de

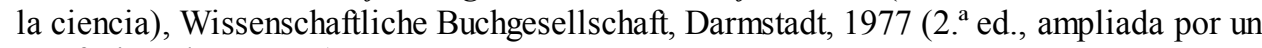
postfacio; ed. or. 1973), 145 págs.

* Struck, Gerhard, Topische Jurisprudenz. Argument und Gemeinplatz in der juristischen Arbeit (Jurisprudencia tópica. Argumento y lugar común en la labor jurídica), Athenäum, Francfort, 1971, 118 págs.

* Struck, Gerhard, Zur Theorie juristischer Argumentation (Sobre la teoría de la argumentación jurídica), Duncker \& Humblot, Berlín, 1977, 162 págs.

* Toulmin, Stephen, The Uses of Argument, Cambridge University Press, Cambridge, 1958, 264 págs.

* Vaz Ferreira, Carlos, Lógica viva (Adaptación práctica y didáctica), Homenaje de la Cámara de Representantes de la República Oriental del Uruguay, vol. IV, Montevideo, 1963 (ed. or. 1910), 320 págs. [De esta obra hay otras ediciones, publicadas por Losada, Buenos Aires.]

* Viehweg, Theodor, Topik und Jurisprudenz. Ein Beitrag zur 
rechtswissenschaftlichen Grundlagenforschung, C. H. Beck (Schwarze Reihe, núm. 110),

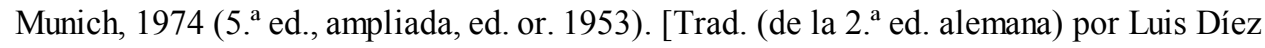
Picazo, Tópica y jurisprudencia, Taurus, Madrid, 1964, 145 págs.]

- Villey, Michel, «Nouvelle rhétorique et Droit naturel», en Michel Villey, Critique de la pensée juridique moderne (douze autres essais), págs. 85-103, Dalloz, París, 1976.

-Villey, Michel, Philosophie du droit, vols. I (Définitions et fins du droit) y II (Les moyens du droit), Précis Dalloz, París, 1978 (2. ${ }^{a}$ ed., corregida y ampliada, del vol. I, XII + 205 págs.) y 1979 (vol. II, 267 págs.). [Hay trad. al castellano publicada por EUNSA, Pamplona.] -Wagner, Heinz, y Haag, Karl, Die moderne Logik in der Rechtswissenschaft (La lógica moderna en la ciencia del derecho), Gehlen, Francfort, 1970, 115 págs. 